DEPARTMENT OF THE INTERIOR UNITED STATES GEOLOGICAL SURVEY

GEORGE OTIS SMITH, DIRECTOR

BULLeTIN 513

\title{
PLIOCENE AND PLEISTOCENE FORAMINIFERA
}

\author{
FROM \\ SOUTHERN CALIFORNIA
}

BY

RUFUS MATHER BAGG, JR.

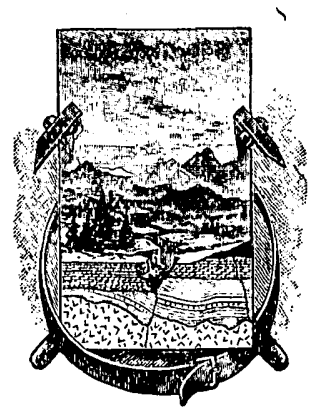

WASHINGTON

GOVERNMENT PRINTING OEFICE 1912 



\section{CONTENTS.}

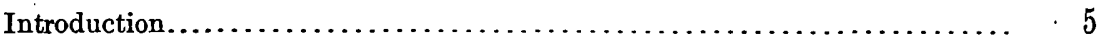

Bibliography.............................................. 20

Outline classification of Foraminifera.............................. 21

Descriptions of the species...................................... 23

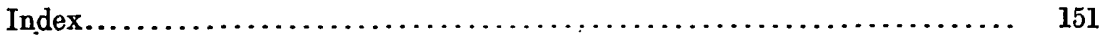

\section{ILLUSTRATIONS.}

Plates I to XXVIII. Foraminifera

Page.

Figure 1. Section showing geologic structure along the water front at San Pedro, Cal...................................... 9

2. Section of strata on the east point of Deadman Island, San Pedro, Cal.............................................. 10

3. Map of San Pedro, Cal., and vicinity ...................... 10 



\section{PLIOCENE AND PLEISTOCENE FORAMINIFERA FROM SOUTHERN CALIFORNIA.}

By Rufus Mather BagG, Jr.

\section{INTRODUCTION.}

The collection of Pliocene fossils discussed in this report was sent to the author through the courtesy of Prof. J. C. Branner, of Leland Stanford Junior University. It is known as the Delos Arnold collection and is the property of Stanford University. The Pleistocene material was collected by the writer about five years ago and a list of species identified, with a few general conclusions concerning them, was then published. ${ }^{1}$ A discussion and a description of this material are presented in this report.

The total number of Pliocene and Pleistocene species and varieties identified is 128 . The Pliocene material consists of highly fossiliferous light-colored yellowish sands and clay sands from Timms Point, San Pedro, Cal. The samples are exceedingly rich in Foraminifera, in a perfect state of preservation, though a few are somewhat waterworn, and contain a very large number of species (105), several of which are so abundant as to constitute a rather typical ooze. The most abundant, as nearly as can be roughly estimated, are Miliolina seminulum (Linnæus), Biloculina ringens (Lamarck), Cassidulina crassa D'Orbigny, C. lævigata D'Orbigny (especially abundant), Polymorphina complanata D'Orbigny, P. compressa D'Orbigny, and Nodosaria pauperata (D'Orbigny). Other species that are common but less abundant than these are Cassidulina subglobosa Brady and a rather unusual form in existing oceans, Frondicularia inæqualis Costa. The cosmopolitan Globigerina bulloides D'Orbigny and Lagena lævis (Montagu), the latter occurring with Lagena marginata (Walker and Boys), are very common at San Pedro.

This rich foraminiferal sand contains numerous fragments of minute Mollusca, echinoderm spines, sponge spicules (haxactinellidan) ostracods, ear bones of fish (otoliths; see Pl. XXVIII, flgs. 13, a-e), and numerous diatoms. An unusually large Cardium (C. major) in this deposit measures half an inch in diameter. Three or four genera 
of the Ostracoda are very abundant and a systematic study of these would yield a number of species. The numerous short delicate echinoid spines show that the sea urchins were well represented in these Pacific waters, as they are to-day off the west coast. The sea urchins of to-day, however, are much more abundant and of larger size than those of the Pliocene.

The Pleistocene material was obtained at Santa Barbara, Cal., from gray sandstone with fossiliferous lenses, more or les indurated in the lower portion and overlain by gravels and sands hardened by calcareous cement, both divisions lying unconformably on the Pliocene. It presents a number of differences from the material of the Pliocene beds near San Pedro, though, as is to be expected in collections from closely adjoining areas, many species occur in both deposits. The forms are even more typical of very cold waters and low temperatures in shoal depths than the Pliocene species and indicate a rapid refrigerating process which must have occurred at the close of the Pliocene and the opening of the Pleistocene. One important fact revealed by this correlation is that the Pliocene beds at San Pedro correspond stratigraphically with the undetermined zones 10 and 11 of the uppermost part of the older Pliocene of England, and therefore represent very late older Pliocene time. The Foraminifera listed in the undetermined zones of Sutton, Sudbourne, Gedgrave, and Aldborough in the correlation table of the monograph on the English Crag, ${ }^{1}$ published by the Paleontographical Society, as representing the upper division of the "Coralline" Crag, just beneath the St. Erth beds, include a very large number of species which are exceedingly common in the Pliocene strata at San Pedro and which appear to be equally large and abundant in the upper layers of the older English Crag. The table on page 7 indicates later views regarding the position of the Crag strata. In the correlation table presented on pages 15 to 19 the Foraminifera found in the English Crag are shown, and the several divisions appearing in the Crag monograph (part 4) are not given.

The following table shows the arrangement of the English Crag and overlying Pleistocene. It includes the upper strata of the lower Crag among the deposits laid down in warm temperate waters, but the species described in the present bulletin, taken as a whole, show that these strata should be grouped with the upper division (cold temperate).

1 Jones, T. R., Parker, W. K., and Brady, H. B., The Foraminifera of the Crag, pt. 1: Paleont. Soc., vol. 19, 1865-1866, App. 2, cols. 10 and 11; and Jones, T. R., Idem, pt. 4: Paleont. Soc., vol. 51, 1897, pp. 373-393. 
Classification of the Pliocene deposits of Britain and their principal foreign equivalents. ${ }^{a}$

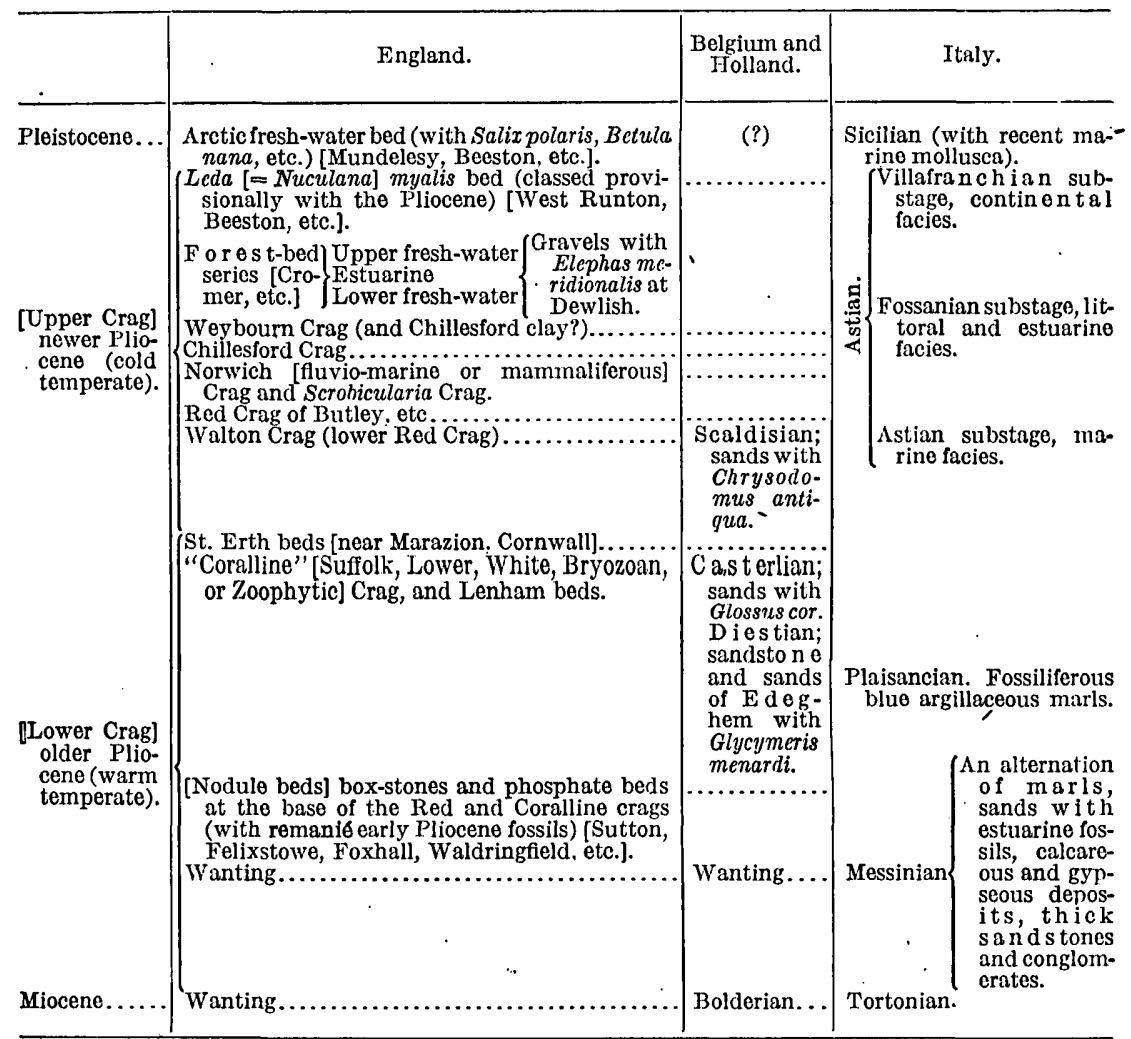

aPaleont. Soc., vol. 49, 1895, p. 79.

The Pleistocene at Santa Barbara, which represents the lowest part of the Pleistocene series, immediately overlying the Pliocene, perhaps corresponds with the Arctic fresh-water beds of the English Pleistocene. Bryozoa are common in both the Pliocene and the Pleistocene strata at Santa Barbara. Minute twinned selenite crystals, apparently formed subsequent to the deposition of the Pliocene of San Pedro, are present, as are also a number of mineral fragments other than quartz. In all 52 species have been identified in the strata at Santa Barbara, and of these Cassidulina lrvigata D'Orbigny, $C$. subglobosa Brady, Biloculina ringens (Lamarck), Miliolina seminulum (Linnæus), Lagena marginata (Walker and Boys), L. melo D'Orbigny, L. striata D'Orbigny, and Nonionina stelligera D'Orbigny are very numerous. In the writer's earlier check list, mentioned above, the significance of the fauna was pointed out in the following words: "The fauna is decidedly north temperate, belonging to the series described by Parker and Jones ${ }^{1}$ in the north Atlantic and Arctic oceans of to-day."

1 Jones, T. R., and Parker, W. K., On some Foraminifera from the North Atlantic and $\Lambda$ rctic oceans, including Davis Strait and Baffins Bay: Philos. Trans., vol. 155, 1865, pp. 325-441, Pls. XII-XIX. 
For comparison with the Pliocene at San Pedro, and to show the difference in the occurrence of the species identified at Santa Barbara in the upper strata at the top of the hills and those in the basal layers along the beach, the following table, which was included in the writer's previous publication, ${ }^{1}$ is given:

\section{Species identified in Pleistocene beds near Santa Barbara.}

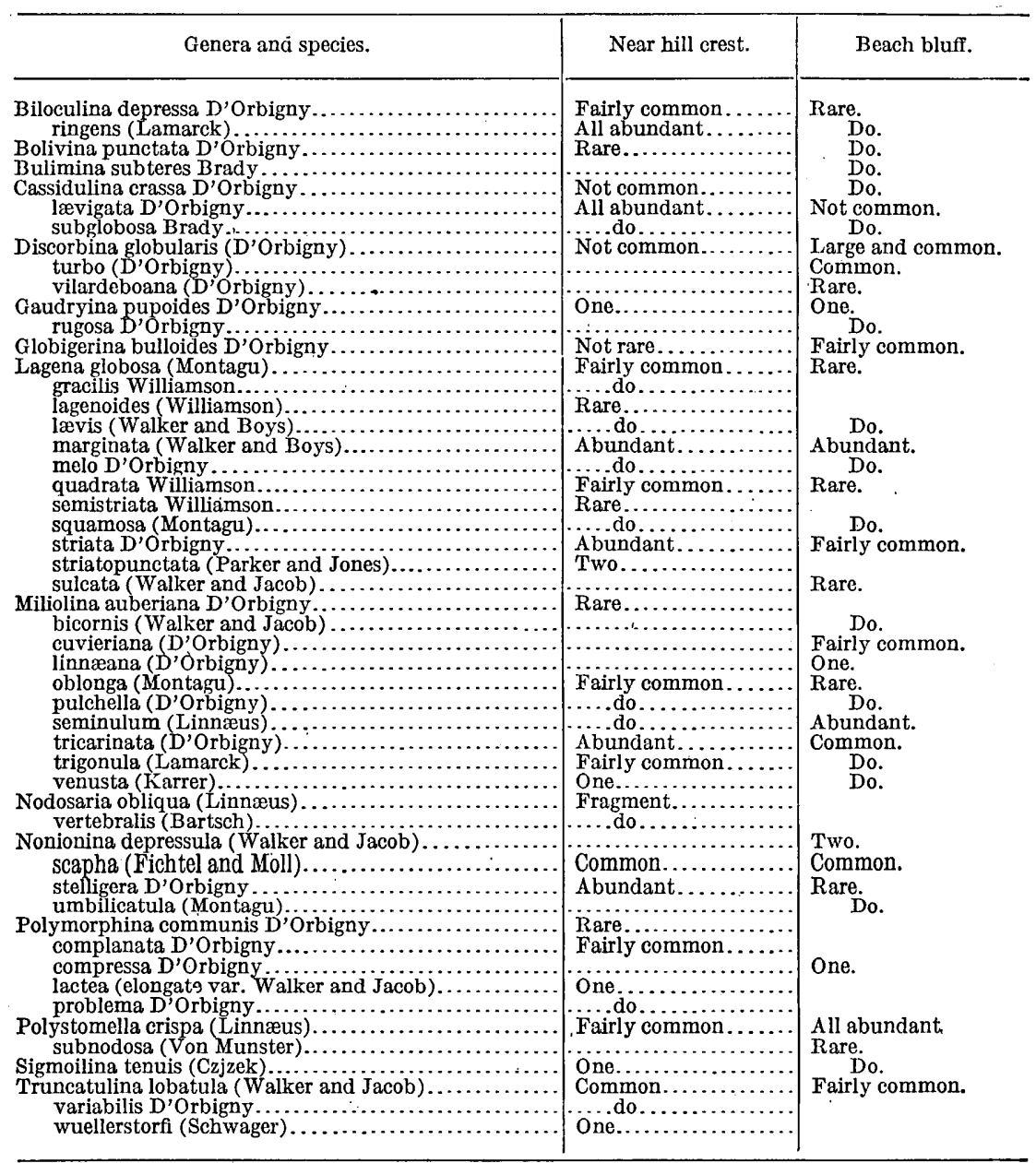

The geology of the Tertiary and Quaternary of California has been described by several authors, and only a few of the more important papers dealing with the deposits under investigation need be cited here. Delos and Ralph Arnold ${ }^{2}$ described the stratigraphy of the San Pedro region in 1902, and Ralph Arnold has published a large memoir on the paleontology of the marine Pliocene and Pleistocene

\footnotetext{
${ }^{1}$ Am. Geologist, vol. 35, 1905, pp. 123-124.

2.Jour. Geology, vol..10, 1902, pp. 117-138.
} 
of San Pedro, with notes on similar formations of the adjacent California coast, ${ }^{1}$ and he has also written an important paper on the Tertiary and Quaternary pectens of California ${ }^{2}$ in which he catalogues certain San Pedro fossils but does not include the Foraminifera.

The conclusions reached by Arnold concerning the San Pedro region are summed up in the following statements. The Pleistocene is most typically represented on the San Pedro shores, but at Timms Point, where the material investigated by the writer was obtained, the Pliocene only is represented, the overlying Pleistocene having been eroded from this point. In adjacent sections, however, the Pleistocene appears unconformably above the Pliocene. (See figs. 1 and 2, both of which are copied from Arnold.)

Ralph Arnold correlates the Pliocene deposits of Packards Hill, at Santa Barbara, with the Pliocene of Timms Point, at San Pedro, and assigns the strata in the bluff at the bathhouse, Santa Barbara, to the lower Pleistocene. It is therefore probable that Packards

S
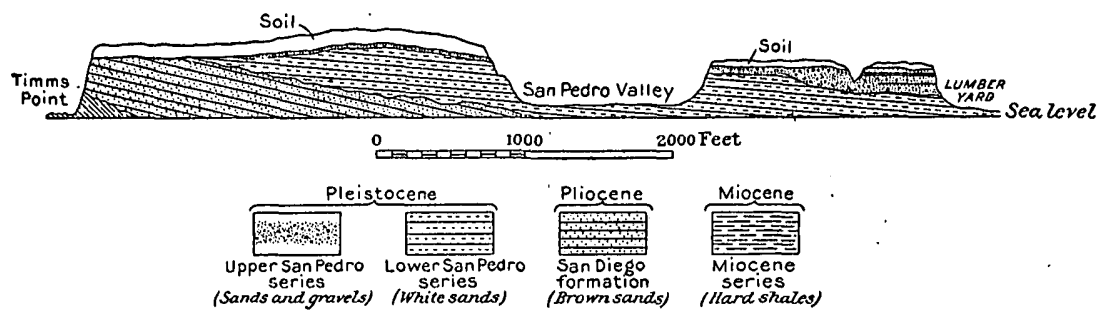

Frgure 1.-Section showing geologic structure along water front at San Pedro, Cal. Vertical scale 20 times the horizontal. (After Ralph Arnold, Mem. California Acad. Sci., vol. 3, PI. XXII.)

Hill is the same as the "bluff at Santa Barbara" which yielded part of the fossils described in this report, and that the "bluff at the bathhouse" is the same as the lower beach bluff.

The stratigraphy of the San Pedro section, according to Arnold, is as follows. The Miocene forms the base of the section. During Pliocene time these beds, which toward the close of the Miocene had been elevated, deformed, and eroded, were again submerged, and a fine fossiliferous yellowish-gray clayey sand was deposited to a thickness of 50 feet. This. Pliocene deposit, Arnold believes, was elevated in post-Pliocene time and was eroded until, at'San Pedro, only the remnants at Deadman Island (fig. 2) and Timms Point now exist. Submergence again occurred in Pleistocene time and the partly eroded Pliocene was covered by fine gray sand to a maximum thickness of 50 feet. At Timms Point this sand lies unconformably upon the Pliocene. Figure 3 shows the location of Timms Point and Deadman Island. 
The Timms Point material investigated was laid down in latest Pliocene time and is closely correlated with the St. Erth beds of the English Crag, which represent the close of Tertiary time. The sand is extremely fossiliferous, and Foraminifera constitute the bulk of the material present.

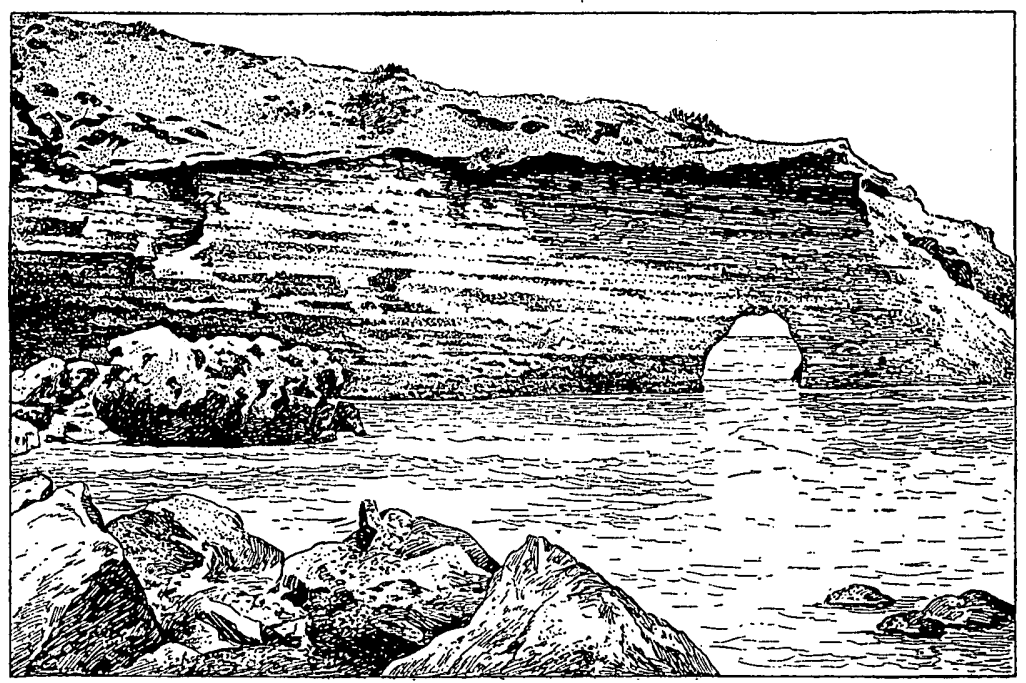

Figure 2.-Section of strata on the east point of Deadman Island, San Pedro, Cal. The Pliocene here is equivalent to the material investigated at Timms Point and to the St. Erth beds of England. (After a photograph by Ralph Arnold.)

The Miocene material at Timms Point has not been examined, but is probably closely related to the Monterey shale, which has been investigated by the writer. ${ }^{1}$

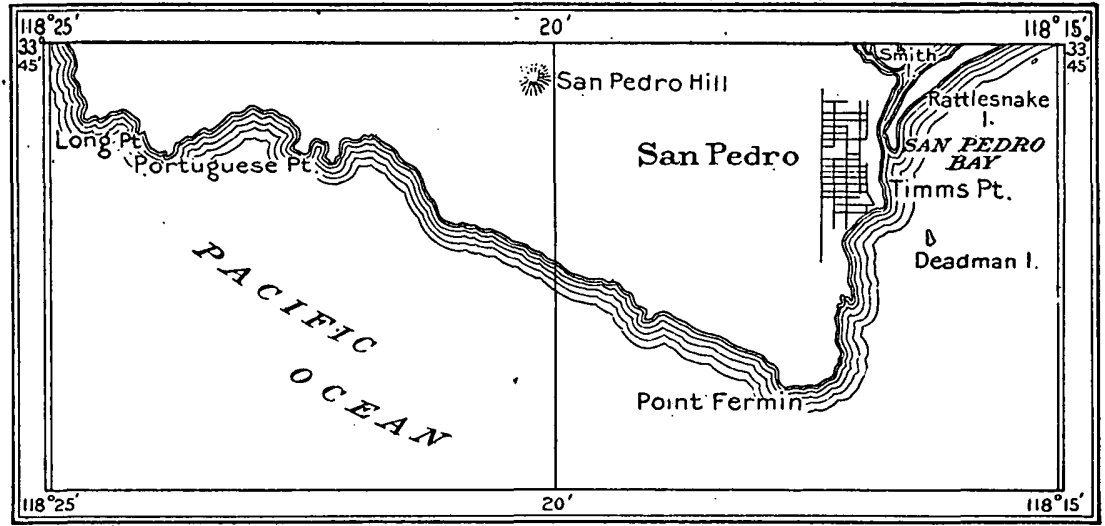

Figure 3.-Map of San Pedro, Cal., and vicinity.

The term San Pedro formation originally designated deposits 100 feet in thickness and was first used by W. H. Dall. ${ }^{2}$ Arnold $^{3}$ uses the

1 Bull. U. S. Geol. Survey No. 268, 1905.

3 Jour. Geology, vol. 10, 1902, p. 124.

2 Eighteenth Ann. Rept. U. S. Geol. Survey, pt. 2, 1898, p. 335. 
term to include "all of the strata of Deadman Island and San Pedro lying stratigraphically above the brown Pliocene sands and below the raised beach formation at Duadman Island."

One of the most significant facts revealed by study of the fossils is that these deposits are not of tropical or warm temperate origin. The Foraminifera are of the types common in the north Atlantic Ocean to-day, and some of the species correspond to forms that inhabit both the south Atlantic and south Pacific. In general, therefore, these Foraminifera are arctic in character, especially the Pleistocene forms. The great abundance of Cassidulina and Polystomella is perhaps sufficient evidence that these strata were laid down in cold waters under conditions similar to those now prevailing in the north Atlantic and Arctic oceans. The cooling of the Pacific was well advanced in Miocene time, and the Pliocene and Pleistocene types indicate that it went on for a long period without interruption. Shoaling of the waters was continuous subsequent to Miocene time, as revealed not only by the composition of the inorganic material of the deposits but even more positively by the Foraminifera present in them. The Miliolidæ are an important group of imperforate Foraminifera which began to be prominent as rock builders early in the Tertiary period. They continued to develop and diversify through Miocene and Pliocene time and are perhaps near their highest development at the present day in temperate and tropical waters. Many of these fossil Miliolidæ of California are characteristic of boreal waters and indicate that shoals existed not far from the coast. A few species, however, belong to the Tropics and a few are distributed widely, with little relation to the temperature of the water, but the preponderance of boreal types is sufficient evidence of the cold water temperatures in late Pliocene and Pleistocene time.

- No Miliolidæ were detected by the writer in the Miocene deposits of California, which were probably laid down in deeper water than the formations considered in this report. The significance of the absence of Miliolidæ is discussed by the writer in the report on the Miocene above mentioned, ${ }^{1}$ and attention will here be called only to the features essential to an understanding of the physical conditions governing the present stratigraphy. The Miocene beds were laid down in waters less than 500 fathoms in depth, but were far enough from the shore to be fine, argillaceous, and siltlike in character, with very thin bedding planes. The ocean was in Miocene time approaching a condition like that of the north Atlantic to-day, and this resemblance was even greater in late Pliocene time. The Pliocene beds considered in this paper were probably laid down at depths not exceeding 100 fathoms, and the Pleistocene beds overlying them were deposited in waters of half this depth, or even less. The prolonged and notable diastrophic 
movements which occurred along the Pacific coast throughout the Tertiary period had given place to minor movements and to a gradual recovery of the continental shelf. This elevation and submergence must have been accompanied by disturbance of offshore currents that resulted in the development of various types of Foraminifera characteristic of temperate-zone waters of the present day.

The San Pedro Foraminifera are well represented in the Italian Pliocene, are less common in Spain, and occur sparingly in Belgium. Most of them, particularly those of the upper strata, are similar to those of the English Crag. Of the 105 Pliocene species found at San Pedro, 55 are present in the English Crag. A few species, especially Uvigerina pygmæa, Truncatulina lobatula, Bulimina pyrula, and Vaginulina legumen, are abundant in the Italian Pliocene.

Among the San Pedro species that are developed at depths of less than 100 fathoms are Miliolina pulchella, M. cuvieriana (at Santa Barbara only), Pulvinulina repanda, and Truncatulina refulgens. Certain species even more typical of shoal waters are present in great abundance in the Pleistocene near Santa Barbara, as is shown by the correlation table on pages 15-19. The Pliocene forms are for the most part unlike those of the Miocene but check rather closely with those of the overlying Pleistocene.

The importance of correlation work and of results shown by the bathymetric tables can not be too strongly emphasized. Many Foraminifera of the present day are pelagic in habit, and presumably the species now found as fossils did not differ from them in this respect. Their distribution is almost unrestricted, owing to the effect of strong ocean currents, but deposits rich in a few characteristic types afford unquestionable evidence of the physical conditions and bathymetric range at the time they were formed.

It is perhaps because of the unstable relations of sea and land that so few foraminiferal deposits have been developed in the earlier stages of the earth's history. Toward the close of the Mesozoic era, however, the boundaries of the oceans as they are to-day were fairly well established, and hence there was in the Cretaceous period a great development of chalk, which is composed very largely of Foraminifera alone.

Only two groups of Protozoa, the Radiolaria and the Foraminifera, have been rock builders in past geologic epochs. These groups are in strong contrast, the Radiolaria being entirely siliceous and the Foraminifera almost wholly calcareous. The former have never been of much value in the study of stratigraphy, inasmuch as their development is most notable in oceanic waters of extreme depth and is at best of more or less local character. Perhaps it is because these great "deeps" did not exist over wide bathymetric depressions through any long geologic period until Tertiary time that we find the Radiolaria 
only in scattered siliceous cherts of nearly all epochs, but they did not become important rock builders until the Tertiary. The Foraminifera, however, have a very wide representation in a large number of deposits, some of which cover large areas and are of great thickness. The forms occurring in some of these deposits are sufficiently limited, generically and specifically, to be of great value to the paleontologist and stratigrapher.

It is an interesting fact that none of the Foraminifera became rock builders until Mississippian time. One of the earliest of the rockbuilding types is Fusulina, a genus of complex structure and of exceptionally large size, which, so far as known, had no previous congeners. The Foraminifera, as a group, must have developed early, but the shallow waters that prevailed through much of Cambrian time and the frequent changes in sea and land during early Paleozoic time, due to the advance and retreat of epicontinental seas, with their effect on ocean temperatures, produced climatic and bathymetric conditions unfavorable to them and probably also affected their food supply. For these reasons their development did not become extensive until the beginning of Mississippian time, when the seas were again deepening. The absence of these fossils in sediments of pre-Mississippian deposition is also due in part to their delicate shell structure and to their microscopic size, two factors which rendered their preservation difficult. The original types of Foraminifera may have given place to larger and stronger genera in later epochs, as a result of greater pressure due to increased depth of the ocean.

Foraminifera flourish best in waters free from sediment and are much less abundant at the mouths of rivers and estuaries. Bottomliving types have a predilection for shoal water, and vary more in size and in shell thickness than the forms inhabiting deeper waters. Most of the living Foraminifera are of pelagic habit and not abyssal in character, and if this holds true of the fossil forms they would have been readily affected by changes in temperature. This statement applies at least to the types which constitute the foraminiferal oozes. The bottom types add little to the deposits of the larger oceans, for where they are best able to develop, as along continental shelves and shallow coast lines, the preponderance of other mechanical and organic sediments prevents the deposit from becoming foraminiferal in character.

Few of the pelagic types occur in the Pliocene near San Pedro, and this condition further suggests proximity to the coast line rather than the deep water of existing oozes. The deposit was probably laid down at a depth of about 100 fathoms. These San Pedro forms are more closely related to the shoal-water species, which existed in relative abundance in comparatively clear waters along the margin of the continental shelf. The Pleistocene deposit at Santa Barbara is even more clearly littoral in character, and was probably laid down 
at less than 50 fathoms. The Miocene waters were probably between 100 and 500 fathoms in depth.

Of the pelagic types which occur at San Pedro, Globigerina bulloides is the most abundant. This species is perhaps culminating to-day but it has had a comparatively long history, for it dates back to th: Lower Cretaceous. Another pelagic type in the deposits of Sar. Pedro is Pulvinulina, but the species $P$. punctulata and $P$. repanda are not characteristic pelagic types of to-day.

The limited vertical distribution of many Foraminifera in preTertiary and early Tertiary time affords several excellent horizon markers. After the Miocene the distribution of the Foraminifera became more localized and their vertical range more extended, so that most of the late types are less valuable as an aid in deciphering the stratigraphy. They furnish evidence of climatic features and bathymetric conditions, however, and preponderance of certain types allows very close correlation with contemporaneous deposits. It is therefore possible to correlate the Pliocene deposits of San Pedro with the St. Erth beds, even though some incongruities exist.

The high percentage of types which have persisted from late Tertiary time to the present, not only among the Foraminifera but also among the Mollusca, makes possible an understanding of the physiographic conditions since the Tertiary period that can not be obtained with regard to earlier geologic ages, owing to the fact that the earlier types have few modern representatives. The diastrophic movements which marked the closing days of the Tertiary on the west coast probably continued into the Pleistocene, making the sea along the coast more shoaly and elevating the border land more than in the Pliocene. The writer believes that the time is ripe for a more thorough study of American Foraminifera in general than has yet been attempted.

It has been impossible to obtain illustrations from actual photographs of many of the fossils described in this report. Most of the figures were made by photographing illustrations already published by other authors, to whom credit is given in the descriptions. The original reference to the description and illustration of type species is given in the text, and to this have been added a number of the more characteristic references to publications where the forms investigated are well described and where synonymy is given, or where the species are best and most typically portrayed. The excellent monograph on the Foraminifera of the Crag, begun by Jones, Brady, and Parker and completed by Jones, has been of invaluable aid in the preparation of this report.

It is hoped that the illustrations of the species given on the accompanying plates may save time for those undertaking investigations of the Foraminifera and make clear the descriptions of the specific characters. 


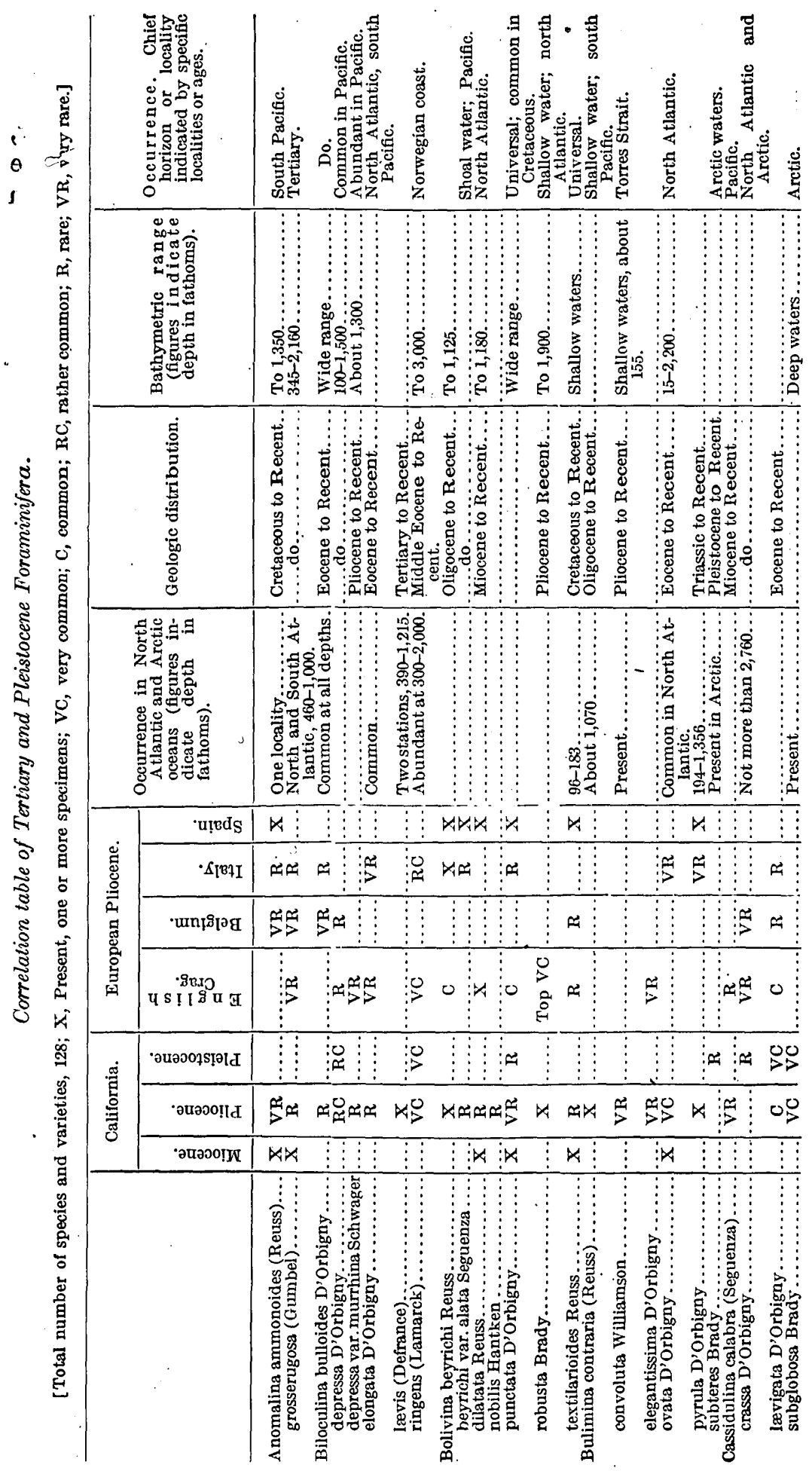

45625는 Bull. 513-12-2 


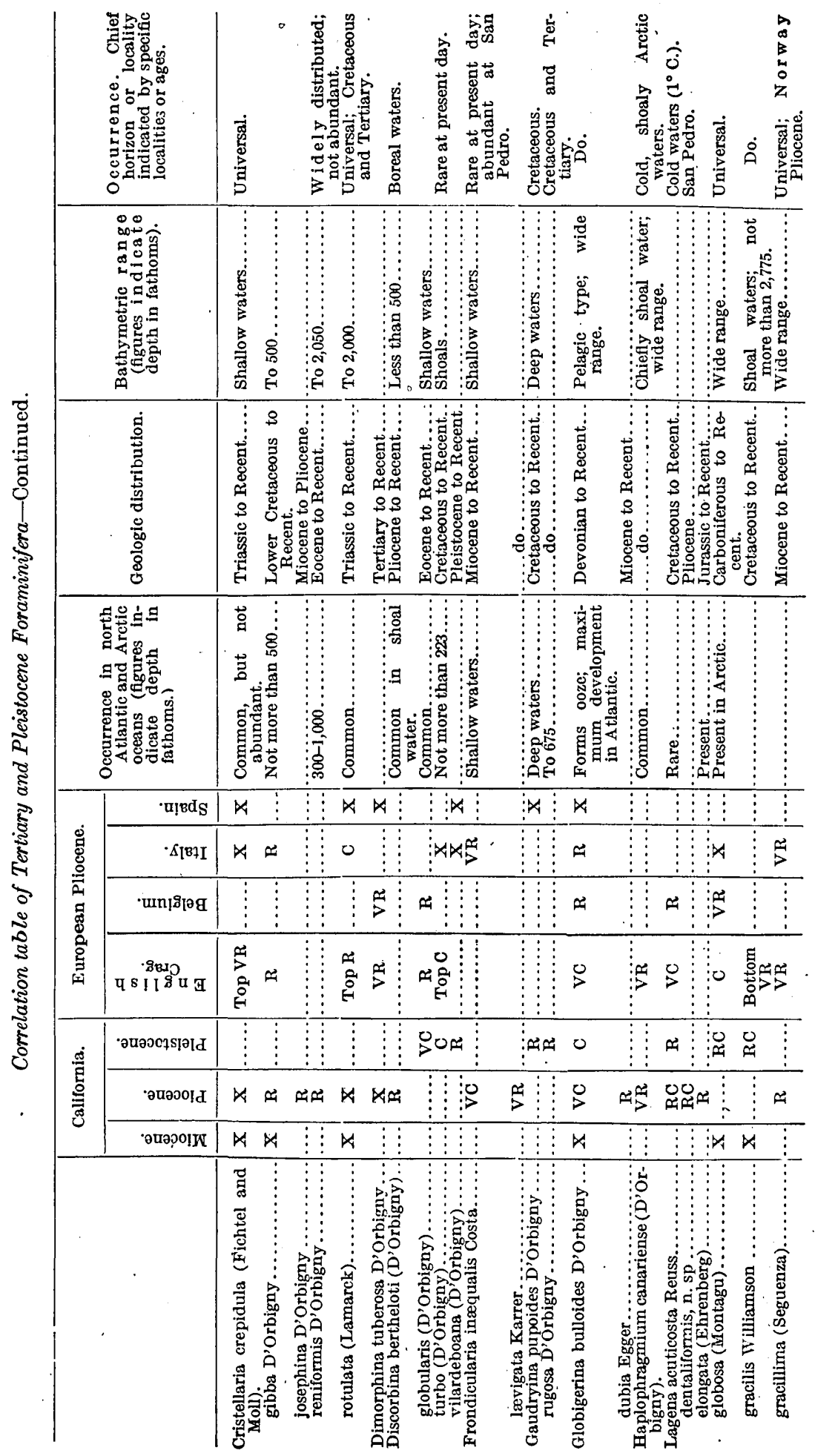




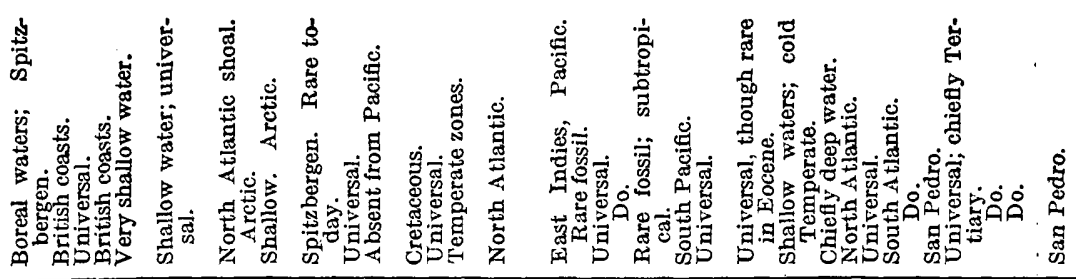

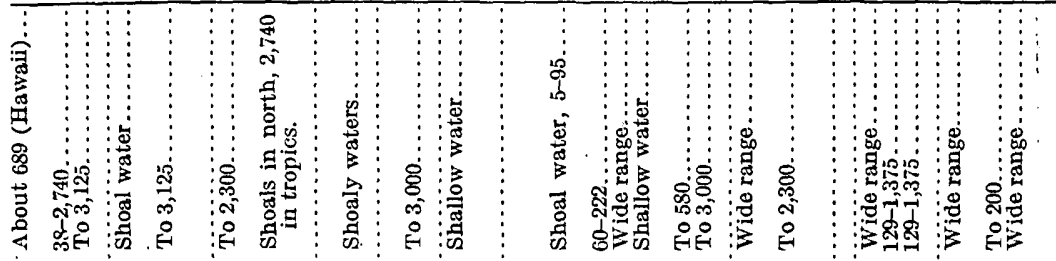

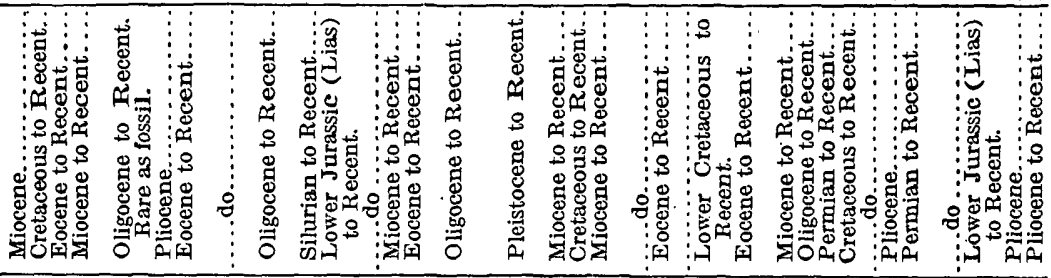

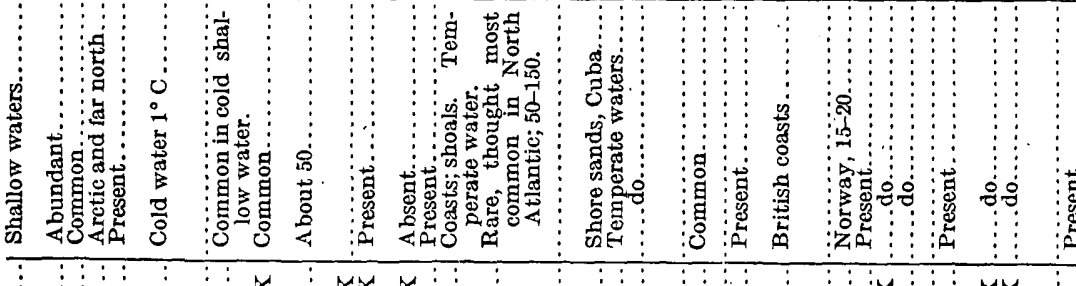

4 我

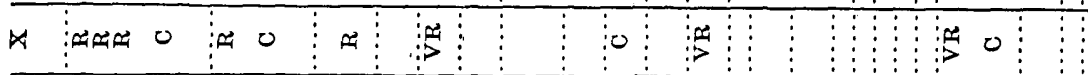

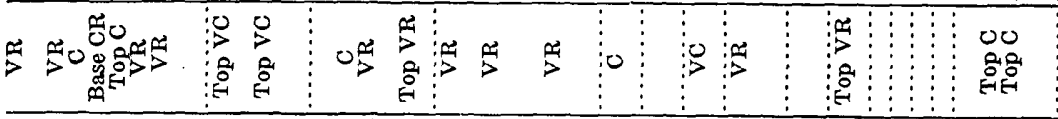

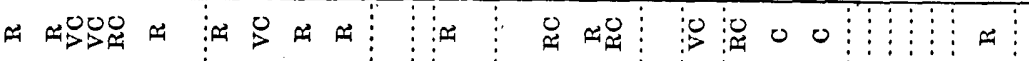

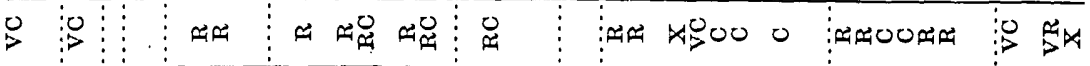

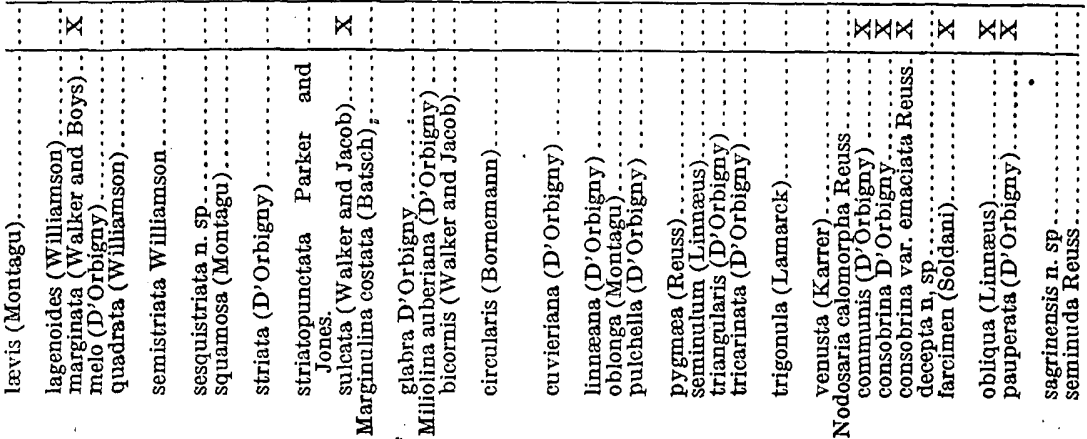




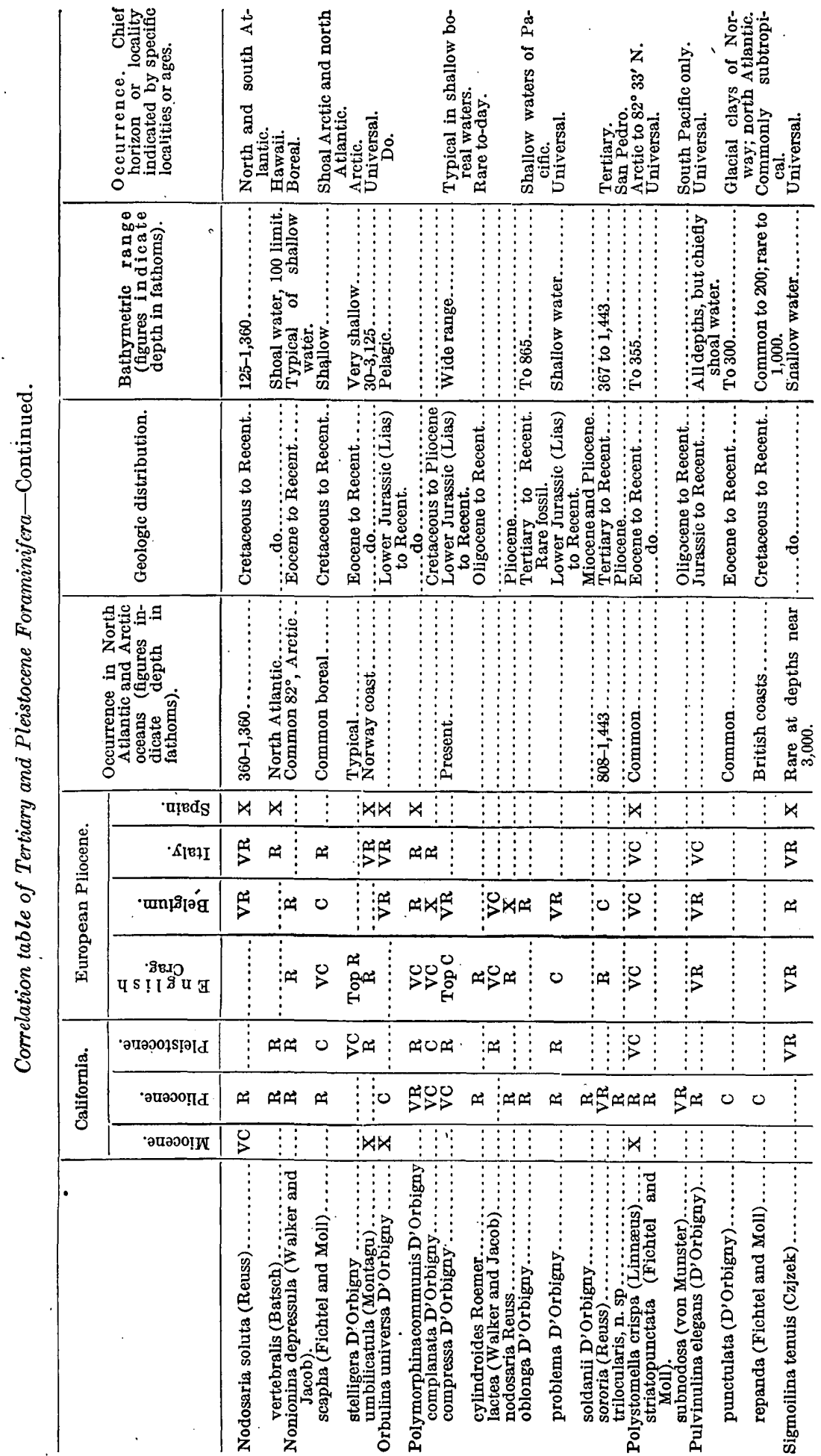



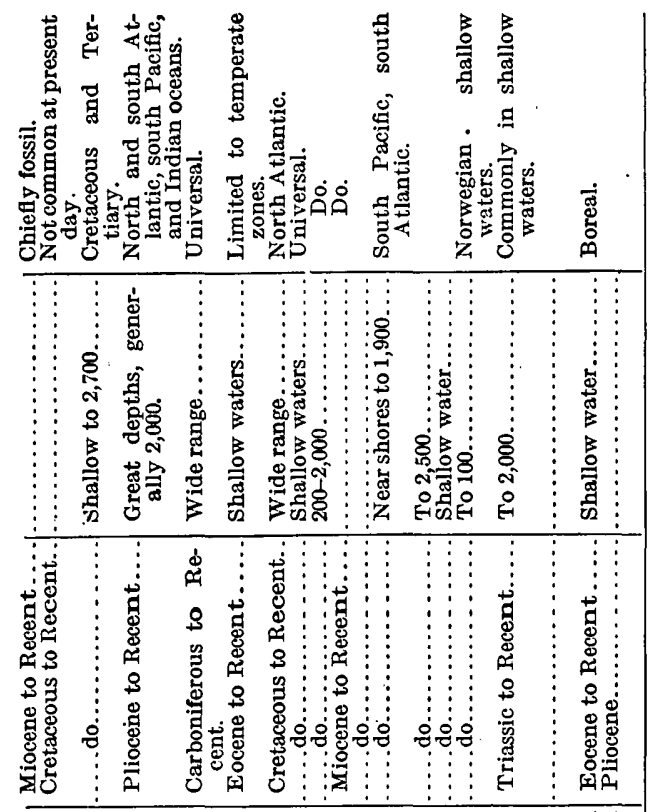

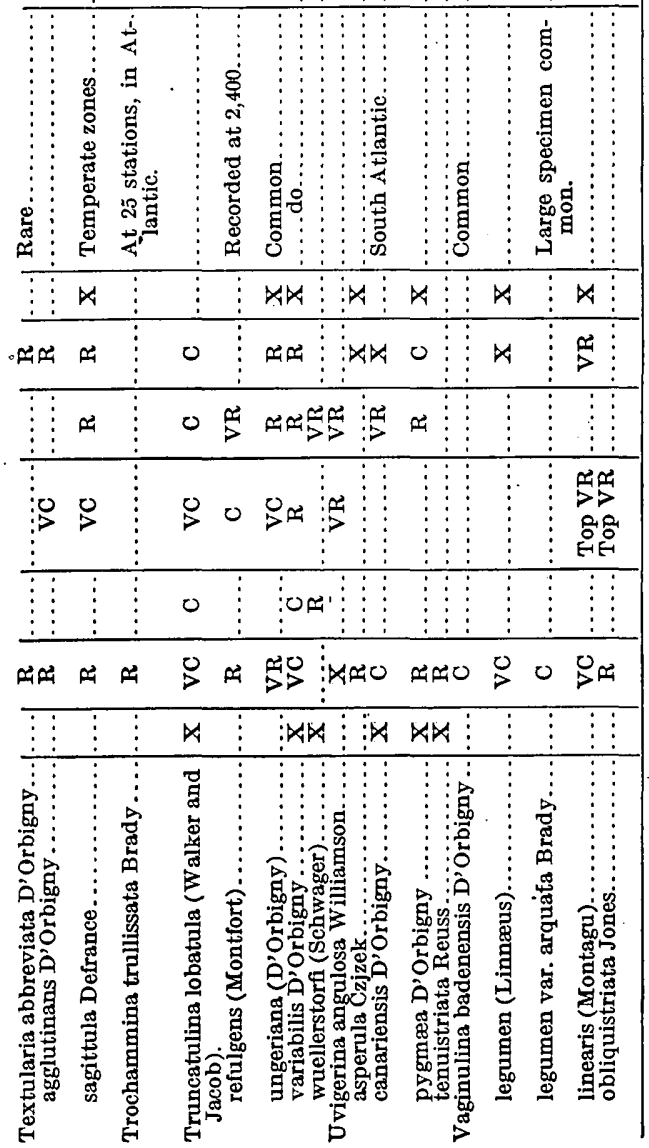




\section{BIBLIOGRAPHY.}

The following bibliography includes only the references most essential for a study of Tertiary and Pleistocene Foraminifera.

DE A mrcrs, G. A., Contribuzione alla conoscenza dei foraminiferi plioceni: Boll. Soc. geol. italiana, vol. 12, 1893, pp. 293-478, Pl. III.

BAgG, R. M., Jr., Miocene Foraminifera from the Monterey shale of California: Bull. U. S. Geol. Survey No. 268, 1905, pp. 78, Pl. XI.

The Tertiary and Pleistocene Foraminifera of the middle Atlantic slope: Bull. Am. Paleontology, vol. 2, No. 10, 1898, pp. 3-54, Pls. I-III.

- Foraminifera collected near the Hawaiian Islands by the steamer Albatross in 1902: Proc. U. S. Nat. Mus., vol. 34, 1908, pp. 113-172, Pl. V.

Brady, H. B., Report on the Foraminifera dredged by H. M. S. Challenger during the years 1873-1876: Report of the scientific results of the voyage of H. M. S. Challenger, vol. 9, (Zoology) 1884, text and plates.

Brady, H. B., Parker, W. K., and Jones, T. R., A monograph on the genus Polymorphina: Trans. Linnæan Soc. London, vol. 27, 1870, pp. 197-253, Pls. XXXIXXLII and text figures.

An indispensable work for Polymorphina investigations.

On some Foraminifera from the Abrolhos Bank: Trans. Zool. Soc. London, vol. 12, pt. 7, 1888, pp. 211-239, Pls. XL-XLVI and chart.

- The Foraminifera of the Crag, part 1: Paleont. Soc., vol. 19 (1865), 1866, pp. 1-72, Pls. I-IV.

Chapman, Frederick, The Foraminifera; an introduction to the study of the Protozoa, Longmans, Green \& Co., 1902.

Flint, J. M., Recent Foraminifera: Rept. U. S. Nat. Mus. for 1897, 1899, pp. 249-349, 80 plates.

A valuable report, with excellent photographic plates of actual specimens.

Goes, Axel, A synopsis of Arctic and Scandinavian Recent marine Foraminifera: Kongl. Svenska Vetenskaps-Akad. Handl., Bd. 25, No. 9, 1894, pp. 1-127, 25 plates.

A valuable report on cold-water types of living Foraminifera.

Jones, T. R., The Foraminifera of the Crag, part 2: Paleont. Soc., vol. 49, 1895, pp. 73-210, Pls. V-VII; part 3: Paleont. Soc., vol. 50, 1896, pp. 211-314; part 4: Paleont. Soc., vol. 51, 1897, pp. 315-402.

Jones, T. R., and Parker, W. K., On some Foraminifera from the north Atlantic and Arctic oceans: Philos. Trans., vol. 155, 1865; pp. 325-441, Pls. XII-XIX, charts and tables (no index).

D'Orbigny, A. D, Voyage dans l'Amérique méridionale,' Foraminifères, vol. 5, pt. 5, 1839, pp. 1-86, 9 plates.

- Foraminifères fossiles du bassin tertiaire de Vienne, Paris, 1846, 312 pp., 21 plates.

Sherbonn, C. D., A bibliography of the Foraminifera, recent and fossil, 1565-1888, London, 1888.

Invaluable for bibliographic work.

An index to the genera and species of the Foraminifera, part1 (A-Non): Smithsonian Misc. Coll., No. 856, 1893; part 2 (Non-Z): Idem, No. 1031, 1896.

Sherborn, C. D., and Chapman, F., On some Microzoa from the London clay, etc.: Jour. Roy. Micr. Soc. London, 2d ser., vol. 6, 1886, pp. 737-764, Pls. I-III.

Williamson, W. C., On the Recent Foraminifera of Great Britain, Ray Soc., London, 1858, pp. 1-107, Pls. I-VII.

A most excellent work, with beautiful plates. 


\section{OUTLINE CLASSIFICATION OF FORAMINIFERA.}

In this classification the genera identified in the Pliocene and Pleistocene of southern California are arranged biologically.

Subkingdom.-Protozoa.

Class.-Rhizopoda.

Order.-Foraminifera (Reticularia).

Family I. Gromidæ

Family II. Miliolidæ:

a. Subfamily Nubeculariinæ............... None.

b. Subfamily Miliolininæ:

Genus Biloculina................6 species and varieties.

Genus Miliolina....................13 species.

- Subgenus Sigmoilina............ species.

c. Subfamily Hauerininæ.................. None.

$d$ Subfamily Peneroplidinæ................ None.

e. Subfamily Alveolininæ.................. None.

' $f$. Subfamily Keramospherinæ............. None.

Family III. Astrorhizidæ:

a. Subfamily Astrorhizinæ................ None.

b. Subfamily Pilulininæ.................. None.

c. Subfamily Saccammininæ............... None.

$d$. Subfamily Rhabdammininæ........... None.

Family IV. Lituolidæ:

a. Subfamily Lituolinæ:

Genus Haplophragmium.............1 species.

b. Subfamily Trochammininx:

Genus Trochammina.................1 species.

c. Subfamily Endothyrinæ................ None.

$d$. Subfamily Loftusiinæ.................. None.

Family V. Textulariidæ:

a. Subfamily Textulariinæ:

Genus Textularia. ...................3 species.

Genus Gaudryina...................2 species.

b. Subfamily Bulimininæ:

Genus Bulimina. ................6 species.

Genus Bolivina...................7 species.

c. Subfamily Cassidulininæ:

Genus Cassidulina...................4 species.

Family VI. Cheilostomellidæ................ None.

Family VII. Lagenidæ:

a. Subfamily Lageninæ:

Genus Lagena.....................17 species.

b. Subfamily Nodosariinæ:

Genus Nodosaria..................11 species.

Genus Frondicularia.................2 species.

Genus Marginulina................. 2 species.

Genus Vaginulina................. 5 species.

Genus Cristellaria.................5 species.

c. Subfamily Polymorphininæ:

Genus Dimorphina................ 1 species.

Genus Polymorphina................11 species.

Genus Uvigerina...................5 species.

d. Subfamily Ramulininæ................ None. 
Subkingdom.-Protozoa-Continued.

Class.-Rhizopoda-Continued.

Order.-Foraminifera-Continued.

Family VIII. Globigerinidæ:

Genus Globigerina. ..............2 species.

Genus Orbulina...................

Family IX. Rotaliidæ:

a. Subfamily Spirillininæ............... None.

b. Subfamily Rotaliinæ:

Genus Discorbina................ 4 species.

Genus Truncatulina..................5 species.

Genus Anomalina..................2 species.

Genus Pulvinulina................. 3 species.

c. Subfamily Tinoporinæ............... None.

Family X. Nummulinidæ:

a. Subfamily Fusulininæ................ None.

b. Subfamily Polystomellinæ:

Genus Nonionina.................. 4 species.

Genus Polystomella................ 3 species.

c. Subfamily Nummulitinæ............... None.

$d$. Subfamily Cycloclypeinæ............... None.

Total, including all varieties or subspecies, 128. 


\title{
DESCRIPTIONS OF THE SPECIES.
}

\author{
Family MILIOLIDÆE. \\ Subfamily MILIOLININ $A$.
}

Genus BILOCULINA.

Biloculina bullomes D'Orbigny.

Plates I, figures 1-4, 10; II, figures 12-14; IV, figure 1.

Biloculina bulloides D'Orbigny, 1826, Annales des sci. nat., vol. 7, p. 297, No. 1, Pl. XVI figs. 1-4, modele 90 .

Biloculina bulloides Schlumberger, 1887, Bull. Soc. géol. France, 3d ser., vol. 15, pp. 573-579, Pl. XV, figs. 10-13, and figs. 1-5 (woodcuts in text).

Description.-Thick-shelled globose test with highly inflated segments and circular aperture. This is in many specimens carried on a slight projection of the ultimate chamber as a short neck. The tongue in the aperture is in some specimens forked, as is shown by Schlumberger in discussing the Grignon deposits of France.

Distribution.-The species occurs in the Eocene deposits of France, but is less frequently recorded in Tertiary deposits than Biloculina ringens. Chapman has noted its occurrence in Tertiary strata at two localities in Victoria, Australia, and it is also found in some parts of the upper Crag (Pliocene) of England, but there the specimens are small and not abundant. In the opinion of the writer, this species is never as important as its relative Biloculina ringens. Possibly it is more properly a temperate-water species, for it has been found off the Hawaiian Islands at depths ranging from 300 to 1,000 fathoms. According to Brady, however, the species is most common in the north Atlantic Ocean and is comparatively rare in other seas. It is rather rare in the Pliocene sands at Timms Point, San Pedro, and the specimens are not typically developed.

\section{Biloculina DePressa D'Orbigny.}

Plate II, figures 5-10.

Biloculina depressa D'Orbigny, 1826, Annales des sci. nat., vol. 7, p. 298, No. 7, modele 91.

Biloculina depressa Brady, 1884, Challenger Rept., vol. 9, p. 145, P1. II, figs. 12, 15-17; Pl. III, figs. 1, 2.

Description.-Test large, glistening, depressed, broadly obovate; always more compressed than in Biloculina ringens, and often with 
periphery carinate and winglike, owing to the widening of the margin of the ultimate chamber at its border. Aperture usually elongate as in $B$. ringens, but subject to great variation, for in some specimens it is tubular.

Distribution.-Eocene of England (London clay), Miocene of Vienna, and Tertiary of Italy. Rare in the English Pliocene Crag.

The writer found many specimiens of this species in dredging off the Hawaiian Islands at depths of 100 to 1,500 fathoms. The form seems to be fairly abundant in the Pliocene sands at Timms Point, San Pedro, and is rather common in the upper bluff series of the Pleistocene of Santa Barbara.

Biloculina IEPRESSA D'Orbigny var. MURRHINA'Schwager.

Plate II, figures 1-4, c.

Biloculina murrhina Schwager, 1866, Novara-Exped., Geol. Theil, vol. 2, p. 203, Pl. VI, fig. 15, a-c.

Biloculina depressa var. murrhyna Bagg, 1908, Proc. U. S. Nat. Mus., vol. 34, p. 117.

Description.-A variety of Biloculina depressa characterized by two angular spinous projections at the aboral end, placed symmetrically with reference to the median line: The type is rare and was dredged by the Challenger in only four localities in the Atlantic and Pacific oceans.

Distribution.-Pliocene and Recent. Rare in the Pliocene sands of San Pedro. This species is abundant at depths of about 1,300 fathoms off the Hawaiian Islands. (Bagg, loc. cit.)

\section{Biloculina elongata D'Orbigny.}

\section{Plates I, figures 17, a-i; II, figures $11, a, b$.}

Biloculina elongata D'Orbigny, 1826, Annales des sci. nat., vol. 7, p. 298, No. 4 .

Biloculina ringens var. patagonica Williamson, 1858, Recent Foram. Great Britain, p. 80, Pl. VII, figs. 175, 176.

Miliola (Biloculina) elongata Parker and Jones, 1865, Philos. Trans., vol. 155, p. 409, Pl. XVII, figs. 88, 90, 91.

Biloculina elongata Jones, 1895, Foram. Crag, pt. 2, Paleont. Soc., vol. 49, pp. 96-98, Pl. III, fig. 28 (end view shows aperture); Pl. VI, fig. 1.

Description.-Test similar to Biloculina ringens but elongate, narrow, and subcylindrical. Aperture more or less subcircular with modified epistomium. Species of Biloculina are fairly constant in shape whatever type of growth they assume, and the elongated oval contour of this species renders its identification easy. The species is, however, subject to modification of the penultimate chamber, and on account of this variation Jones has distinguished three groups of related types. The first of these includes those forms with exposed penultimate segment not pyriform, the second. embraces those with pyriform 
penultimate chamber, and the third would include types belonging to other species showing the pyriform penultimate chamber in exposed portion. The species has a wide geographic distribution to-day, but is most common in the north Atlantic.

Distribution.-Eocene to Recent. The form is rare in the Pliocene of San Pedro.

\section{Brloculina latis (Defrance).}

Plates I, figures 18-22; III, figures 6, a, b, 7 a, b.

Pyrgo lævis Defrance, 1824, Dict. sci. nat., vol. 32, p. 273, Atlas, Pl. LXXXVIII, fig. 2. Biloculina lavis Brady, 1884, Challenger Rept., vol. 9, p. 146, Pl. II, figs. $13,14$.

Biloculina lævis Goes, 1894, Kongl. Svenska Vetenskaps-Akad. Handl., Bd. 25, No. 9, p. 119, Pl. XXIV, figs. 914-918.

Description.-Test small, with the same general outline as Biloculina depressa but differing from it in being bicarinate. This secondary peripheral ridge is faintly developed and is due to the fact that the junction of each new chamber and the preceding ones lies a little within the periphery of the latter, so that the larger keel is flanked by a smaller edge of the penultimate chamber. The aperture is a narrow, horseshoe-shaped opening, with a lingual bar flaring at the center.

Distribution.-Tertiary of Franç (Defrance); Recent. Three specimens were found at San Pedro.

The' Challenger dredged the species at two stations in the north Atlantic at depths of 390 and 1,215.fathoms, and it was also found in the shoal waters of Humboldt Bay, Papua (Brady).

\section{Biloculina Ringens (Lamarck).}

Plates I, figures 5-9, 11-16; III, figures 1-3.

Miliolites ringens Lamarck, 1804, Annales du Muséum, vol. 5, p. 351; vol. 9, Pl. XVII, fig. 1.

Biloculina ringens Williamson, 1858, Recent Foram. Great Britain, p. 79, P1. VI, figs. 169-171.

Description.-Williamson gives the following description of this species:

Shell oval; spherical; its ultimate segment projecting at each extremity beyond the penultimate one; with a rounded or but slightly angular margin. Septal aperture round or transversely ovate, at the anterior extremity of the ultimate segment, which is obliquely truncated by it. A small tooth, usually more or less bifid, but of variable form, projects from the inner and inferior border of the septal aperture. Texture porcelaneous, hue opaque, white, glossy.

Schlumberger ${ }^{1}$ has described this species and its congener $B$.

1 Schlumberger, C., Bull. Soc. g6́ol. France, 3d ser., vol. 15, 1887, pp. 574-584, Pl. XV, 9 woodcuts in text. 
bulloides in great detail and has shown by numerous cross sections, two of which are copied in this report (Pl. I, figs. 10,11) the method of growth in the two species.

In 1867 Felix Karrer ${ }^{1}$ described a similar species from the Upper Jurassic under the name Biloculina antiqua, which Jones, Parker, and Brady considered a synonym of $B$. ringens. Biloculina ringens was one of the earliest Foraminifera studied, for it was investigated as early as 1795 by Soldani. It is a typical species of the genus Biloculina, showing a moderate inflation of the chambers. Biloculina depressa is much more compressed laterally and Biloculina bulloides is much more globose.

The specimens from San Pedro attain a large size, some of them measuring an eighth of an inch in diameter.

Distribution.-This species wasfirst discovered in the middle Eocene beds of the Paris Basin and is not rare in many Miocene and late Tertiary deposits. It is rather abundant in the Coralline Crag (older Pliocene) of England and less common in the Red Crag (newer Pliocene). The species is exceedingly abundant in the Timms Point material and in the upper Pleistocene at Santa Barbara but is not common in the strata at the base of the bluffs.

The species is fairly common in the northern part of the north Atlantic at depths of 300 to 2,000 fathoms or more and at temperatures of $32^{\circ}$ to $34.9^{\circ} \mathrm{F}$. It is also common in dredgings off the coast of Norway. In places the mud is a typical Biloculina mud, the shells constituting some 50 per cent of the material dredged. The Challenger expedition obtained this species from shoal tidewaters down to depths of nearly 3,000 fathoms.

\section{Genus MILIOLINA.}

\section{Miliolina auberiana (D'Orbigny).}

Plates IV, figures 2, a, b, 8; VI, figures 6, a, b.

Quinqueloculina auberiana D'Orbigny, 1839, Foram. Cuba, p. 167, P1. XII, figs. 1-3. Quinqueloculina`ungeriana D'Orbigny, 1846, Foram. foss. Vienne, p. 291, Pl. XVIII, figs. 22-24.

Miliolina auberiana (D’Orbigny) Brady, 1884, Challenger Rept., vol. 9, p. 162, P1. V, figs. $8,9$.

Miliolina auberiana Goes, 1894, Kongl. Svenska Vetenskaps-Akad. Handl., Bd. 25, No. 9, p. 109, Pl. XIX, figs. 844, 844e.

Miliolina auberiana Flint, 1899, Recent Foram.: Rept. U. S. Nat. Mus. for 1897, p. 298, pl. 43, fig. 6 .

Description.-Test triangular in cross section; larger and more circular than Miliolina seminulum (Linnæus). Segments rather sharp and angular at margins, but not so subcarinate as Miliolina cuvieriana 
(D'Orbigny). The San Pedro specimens are large but somewhat bruised and waterworn.

Distribution.-Miocene to Recent. Not uncommon in the Pliocene of San Pedro, but not found in the Pleistocene at Santa Barbara. This species is found in the north and south Atlantic and also in the Tropics, apparently at all depths.

\section{Miliolina BICORNIs (Walker and Jacob).}

Plates III, figures 4, a, b, 5; IV, figure 4; V, figures 1, a-h.

Serpula bicornis Walker and Jacob, 1798, Adam's Essays, Kanmacher's ed., p. 633, PI. XIV, fig. 2.

Miliolina bicornis Brady, 1884, Challenger Rept., vol. 9, p. 171, Pl. VI, figs. 9, 11, 12. Miliolina bicornis Goes, 1894, Kongl. Svenska Vetenskaps-Akad. Handl., Bd. 25, No. 9, p. 113, Pl. XXI, figs. 860, 861.

Description.-Test milioline, compressed, irregular. in outline, with ultimate chamber large and projecting well posteriorly beyond preceding one. The surface is ornamented with striæ, which constitute the chief characteristic of the species. These vary from very numerous, rather fine costæ to a few prominent ribs and may be sinuate, oblique, zigzag, parallel, or even reticulate. Brady has shown in his monograph on the Challenger Foraminifera that these forms can be grouped roughly into several divisions, each of which has its analogue in the smooth-she?'ed types. This species is, however, closely allied to the costate-shelled Miliotina pulchella (D'Orbigny).

Distribution.-Miocene to Recent. This species is at the present day confined chiefly to very shallow coast waters of temperate and subtropical seas. It is present in the Pleistocene of Santa Barbara, but was not obtained from the Pliocene sands of San Pedro, which are so full of Miliolidæ as to make its absence remarkable. One broken specimen of Miliolina pulchella was obtained at San Pedro, however.

\section{MILIOLINA CIRCULARIS (Bornemann).}

Plate VI, figure 3.

Triloculina circularis Bornemann, 1855, Zeitschr. Deutsch. geol. Gesell., vol. 7, p. 349, Pl. XIX, fig. 4.

Miliolina circularis Flint, 1899, Recent Foram.: Rept. U. S. Nat. Mus. for 1897, p. 298, pl. 44, fig. 1.

Description.-Flint gives the following description of this species:

Smooth, slightly compressed, nearly circular in broadest outline; chambers inflated; aperture a crescentic slit with arched upper and thin projecting lip. Length about 0.75 millimeter ( $\frac{1}{32}$ inch).

According to Brady this species can hardly be distinguished from Miliolina subrotunda (Montagu), but it is thicker and more tumid, 
and the final segment is unusually convex and embracing. The aperture is a simple crescentic slit; in Miliolina subrotunda the aperture has a milioline tooth. The form is much more obtuse than Miliolina seminulum (Linnæus) and the other species with which it is associated in California, the largest specimens obtained by the writer measuring only 1.4 millimeters in greatest diameter.

Distribution.-This species was originally described from the Tertiary Septaria clays of Germany. It is found rather sparingly in the Pliocene of San Pedro, but is absent from the Pleistocene of Santa Barbara. The species is rare in existing oceans, occurring chiefly in the north Atlantic, at depths of 50 to 150 fathoms.

\section{Miliolina cuvieriana (D'Orbigny).}

Plate VI; figures 1, a-c.

Quinqueloculina cuvieriana D'Orbigny, 1839, Foram. Cuba, p. 164, PI. XI, figs. 19-21. Quinqueloculina lamarckiana D'Orbigny, 1839, Foram. Cuba, p. 164, Pl. XI, figs. 14, 15. Miliolina cuvieriana Brady, 1884, Challenger Rept., vol. 9, p. 164, Pl. XI, figs. 12, $\mathrm{a}, \mathrm{b}, \mathrm{c}$.

Description.-Test large; smooth-shelled, with very sharp segmented margins on all five visible chambers (hence D'Orbigny's name Quinqueloculina).

The two species described by D'Orbigny under the terms $Q$. lamarckiana and $Q$. cuvieriana are evidently only varieties of the same species and Brady has pointed out that these terms should be treated as synonyms. The species is closely allied to Miliolina auberiana (D'Orbigny), but the latter is not so carinate on the chamber margins and is more symmetrical in growth.

Distribution.-Pleistocene and Recent. D'Orbigny obtained his specimens from the shore sands of Cuba and Jamaica. The form is a very shoal water type and was obtained by the Challenger at depths ranging from 5 to 95 fathoms at five stations, chiefly in the East Indies region. It was found in the beach-bluff deposits at Santa Barbara but was absent from the upper series and was not recognized in the Pliocene sands at San Pedro.

\section{Miliolina linnateana (D'Orbigny).}

Plate III, figures 8, a-c, 9, a-c.

Triloculina linnæana D'Orbigny, 1839, Foram. Cuba, p. 153, Pl. IX, figs. 11-13.

Miliolina linnæana Brady, 1884, Challenger Rept., vol. 9, p. 174, Pl. VI, figs. 15-20. Miliolina linnæana Flint, 1899, Recent Foram.: Rept. U. S. Nat. Mus. for 1897, p. 300, pl. 46 , fig. 3 .

Description.-Test similar to Miliolina bicornis (Walker and Jacob) but with the surface marked by a few large, well-defined costæ in place of fine striations. The aperture is round and toothed. 
Distribution.-Miocene to Recent; not common in late Tertiary deposits. This form is rather widely distributed in the Tropics and elsewhere, usually at depths of less than 200 fathoms (60 to 222, according to Flint). One specimen was found in the Santa Barbara beach bluffs, but the species was not recognized in the Pliocene of San Pedro.

\section{Miliolina oblonga (Montagu).}

Plate IV, figures 5, 6, a, b.

Vermiculum Montagu, 1803, Test. Brit., p. 522, P1. XIV, fig. 9.

Miliolina seminulum var. oblonga Williamson, 1858. Recent Foram. Great Britain, p. 86; Pl. VII, figs. 186, 187.

Miliolina oblonga Brady, 1884, Challenger Rept., vol. 9, p. 160, Pl. V, fig. 3.

Miliolina oblonga Goes, 1894, Kongl. Svenska Vetenskaps-Akad. Handl., Bd. 25, No. 9 , p. 110 , Pl. XX, figs. 850,850 f.

Miliolina oblonga Jones, 1895, Foram. Crag, pt. 2: Paleont. Soc., vol. 49, p. 120 (pt. 1, p. 7), Pl. III, figs. 31, 32; Pl. V, fig. 5.

Description.-Test rather small and slender, smooth-shelled and oblong, as the.specific term implies. The shell is usually triloculine but may be quinqueloculine in its mature development. Generally about three chambers show on one side. The end view shows a narrow horseshoe-shaped aperture, slightly notched and with a broad tooth. The end view of the shell is somewhat circular, owing to the rounding of segments at their border. The San Pedro specimens were about 0.8 millimeter long.

Distribution.-This species occurs in the Upper Chalk of Taplow and the London clay. It is most abundant in Pliocene beds. The few specimens found in the Pliocene of San Pedro are not very typical. Several specimens were obtained in the Pleistocene of Santa Barbara near the crest of the hill.

The form is present to-day in all seas and at all depths. It is, however, best developed in the shallow waters of the temperate zones.

\section{Miliolina PUlchella (D’Orbigny).}

Plate V, figures 3, a-c, 4, a, b.

Adelosina pulchella D'Orbigny, 1846, Foram. foss. Vienne, p. 303, Pl. XX, figs. 25-30. Miliolina pulchella Brady, 1884, Challenger Rept., vol. 9, p. 174, P1. VI, figs. 13, 14; Pl. III, figs. 10-13 (Young).

Miliolina pulchella Goes, 1894, Kongl. Svenska Vetenskaps-Akad. Handl., Bd. 25, No. 9, p. 114, Pl. XXI, figs. 862-864.

Miliolina pulchella Jones, 1895, Foram. Crag, pt. 2: Paleont. Soc., vol. 49, p. 123, Pl. IV, fig. 3; Pl. VI, fig. 3.

Description.-Test irregular, large, strongly costate; built on plan of Quinqueloculina. Surface costæ subject to marked variation, especially in prominence of striæ. 
Distribution.-Miocene to Recent. Rather uncommon in fossil state, and less abundant to-day than many of its relatives. It is typically developed in the shallow water of temperate and subtropical oceans. It was found in the English Crag, and fragmentary remains were obtained in the Pliocene of San Pedro.

\section{Miliolina PYGMaea (Reuss)}

\section{Plate V, figures 2, a, b.}

Quinqueloculina pygmæa Reuss, 1850, Denkschr. Akad. Wiss., vol. 1, p. 384, Pl. I, fig. 3 .

Quinqueloculina lucida Karrer, 1868, Sitzungsber. Akad. Wiss. Wien, vol. 57, p. 147, Pl. II, fig. 7.

Miliolina pygmæa Brady, 1884, Challenger Rept., vol. 9, p. 163, Pl. CXIII, fig. 16.

Description.- Test minute, elongate, consisting of five or more segments almost tubular in shape, closely and unsymmetrically enwrapped about a vertical axis. Surface of shell smooth. Test somewhat resembles Miliolina oblonga (Montagu), but has more segments visible.

Distribution.-Miocene of Kostej; Pliocene of San Pedro (one specimen, greatest diameter 0.4 millimeter); Recent, dredged by the Challenger at ten stations, chiefly in the south Pacific, at depths from a few fathoms down to 580 fathoms.

\section{Miliolina Seminulum (Linnæus).}

Plate IV, figures $9, \mathrm{a}, \mathrm{b}$.

Serpula seminulum Linnæus, 1767, Syst. Nat., 12th ed., p. 1264, No. 791; 1788, 13th (Gmelin's) ed., p. 3739, No. 2.

Mitiolina seminulum Williamson, 1858, Recent Foram. Great Britain, p. 86, Pl. VII, figs. 183-185.

Miliolina seminulum Brady, 1884, Challenger Rept., vol. 9, pp. 157-160, figs. 3, a-c; Pl. V, fig. 6.

Miliolina seminulum Goes, 1894, Kongl. Svenska Vetenskaps-Akad. Handl., Bd. 25, No. 9, p. 108, Pl. XVIII, figs. 838-838n; Pl. XIX, figs. 840-843.

Miliolina (Quinqueloculina) seminulum Chapman, 1902, The Foraminifera, p. 92, pl. 3 , figs. E, e.

Miliolina seminulum Flint, 1899, Recent Foram.: Rept. U. S. Nat. Mus. for 1897, p. 297, pl. 43 , fig. 2 .

Description.-Flint gives the following description of this species:

Contour as seen from above oval, from the end or side triangular, with rounded angles; surface smooth, with the clear white luster of porcelain characteristic of the Miliolidæ. Segments somewhat inflated, usually four of them partially visible on one side and three on the other; aperture round or oval, with a conspicuous appendicular tooth. Length 1.25 millimeters $(1 / 20 \mathrm{inch})$. The species is common in every latitude and at all depths.

Distribution.-Eocene to Recent. This is one of the best-known types of Miliolina and is probably the most common fossil of the 
group in Tertiary deposits. Abundant in the Pleistocene beds at Santa Barbara and even more common in the Pliocene of San Pedro, being scarcely less abundant than Biloculina ringens (Lamarck) and $B$. bulloides D'Orbigny at the same localities.

\section{Miliolina triangularis (D'Orbigny).}

Plate IV, figures 3 , a-f.

Quinqueloculina triangularis D'Orbigny, 1826, Annales des sci. nat., vol. 7, 302, No. 34 . Quinqueloculina triangularis D'Orbigny, 1846, Foram. foss. Vienne, p. 288, Pl. XVIII, figs. 7-9.

Miliolina triangularis Jones, 1895, Foram. Crag, pt. 2: Paleont. Soc., vol. 49, p. 118, Pl. IV, fig. 1; Pl. VI, fig. 2.

Description.-This is a very large tribedral Miliolina similar to $M$. trigonula (Lamarck) and $M$. tricarinata (D'Orbigny) but less sharply keeled. It appears to be a variety of Miliolina seminulum (Linnæus). According to Jones, $M$. subrotunda is a near ally.

Distribution.-Tertiary and Recent, probably coextensive with M. tricarinata. Not uncommon in the Pliocene of San Pedro.

\section{Mrliolina tricarinata (D'Orbigny).}

Plates V, figures 5, a-f; VI, figure 5.

Triloculina tricarinata D'Orbigny, 1826, Annales des sci. nat., vol. 7, p. 299, No. 7, modele 94 .

Triloculina gibba D'Orbigny, 1846, Foram. foss. Vienne, p. 274, P1. XVI, figs. 22-24. Miliolina tricarinata Brady, Parker, and Jones, 1888, Trans. Zool. Soc. London, vol. 12 , pt. 7, p. 215, P1. XL, fig. 32 .

Miliolina tricarinata Goes, 1894, Kongl. Svenska Vetenskaps-Akad. Handl., Bd. 25, No. 9, p. 114, Pl. XXI, figs. 866-869.

Description.-A triloculine symmetrical Miliolina with segments arranged typically as in D'Orbigny's genus Cruciloculina. (See Cruciloculina triangularis $\mathrm{D}^{\prime}$ Orbigny, ${ }^{1}$ which is perhaps a synonym of the present species.)

The margin of the chambers is sharply angular, almost subcarinate. Miliolina trigonula (Lamarck) has the same triangular arrangement of the segments, but the edges of the chambers of the latter are rounded. A similar species which has been confused with Miliolina tricarinata is $M$. triangularis (D'Orbigny), but this is regarded by Jones (see references under description of $M$. triangularis) as specifically distinct. M. triangularis is perhaps a large trihedral variety of Miliolina seminulum (Linnæus).

Distribution.-Cretaceous (Gault) to Recent, but rare in the Eocene. Not rare in the Pliocene of San Pedro, and common in the Pleistocene of Santa Barbara. Found in every ocean and at all depths.

1 Voyage dans l'Amérique méridionale, Foraminifères, vol. 5, pt. 5, 1839, p. 72, Pl. IX, figs. 11, 12. $45625^{\circ}-$ Bull. $513-12-3$ 


\section{Miliolina trigonula (Lamarck).}

Plates IV, figures 7, a-c; VI, figure 4.

Miliolites trigonula Lamarck, 1804, Annales du Muséum, vol. 5, p. 351, No. 3; 1822, Animaux sans vertèbres, vol. 7, p. 612 , No. 3 .

Triloculina austriaca D'Orbigny, 1846, Foram. foss. Vienne, p. 275, Pl. XVI, figs. 25-27.

Miliolina trigonula Williamson, 1858, Recent Foram. Great Britain, p. S4, PI. VII, figs. 180-182.

Miliolina trigonula Brady, 1884, Challenger Rept., vol. 9, p. 164, Pl. III, figs. 15, 16. Miliolina trigonula Goes, 1894, Kongl. Svenska Vetenskaps-Akad. Handl., Bd. 25, No. 9, p. 115, Pl. XXIII, fig. 870.

Description. - Miliolina trigonula is separated from $M$. tricarinata chiefly by the comparative roundness of the three salient chambers. The third chamber' is not prominent, so that the form approaches the Biloculina type. The ultimate inclosing segment in some forms projects into a slight necklike extension, which carries the horseshoeshaped aperture.

Distribution.-Miliolina trigonula occurs in the lower Tertiary (London clay) and in all the succeeding formations. It is less common as a fossil than some of its congeners, but in existing oceans it has a very wide distribution. According to Brady, it never reaches polar seas, though it is common off the British coasts and is a typical shallow-water form of temperate zones. Its bathymetric range is wide, for it is found at 2,300 fathoms, though most abundant in depths of less than 100 fathoms. Although this species is perhaps best known as a Pliocence and Pleistocene fossil, it does not appear to be recorded from the English Crag. It is common in the lower Pleistocene beach-bluff deposits at Santa Barbara and also in the Pliocene of San Pedro.

\section{Miliolina venusta (Karrer).}

Plate VI, figure 2.

Quinqueloculina venusta Karrer, 1868, Sitzungsber. Akad. Wiss. Wien, vol. 57, p. 147, Pl. II, fig. 6.

Miliolina venusta Brady, 1884, Challenger Rept., vol. 9, p. 162, Pl. V, figs. 5, 6.

Description.-Test elongate, oval, with the three outermost segments. subcarinate. Oral end of ultimate chamber slightly prolonged. This form is essentially a deep-water type.

Distribution.-Miocene to Recent. Common in the Pleistocene beach-bluff strata of Santa Barbara, but not recognized in the Pliocene of San Pedro. 


\title{
Subgenus SIGMOILINA.
}

\section{Sigmoilina (Spiroloculina in part) tenuis (Czjzek).}

Plate VIII, figures 9 , a-f.

Quinqueloculina tenuis Czjzek, 1847, Haidinger's Naturw. Abhandl., vol. 2, p. 149, Pl. XIII, figs. 31-34.

Spiroloculina tenuis Brady, 1884, Challenger Rept., vol. 9, p. 152, Pl. X, figs. 7-1.1.

Sigmoilina tenuis Jones, 1895, Foram. Crag, pt. 2: Paleont. Soc., vol. 49, p. 125, Pl. VII, fig. 2.

Description. - The subgenus Sigmoilina was established by Schlumberger in 1887, and as defined includes a number of types formerly considered under the genus Spiroloculina. The chambers are alternately placed about the two megasphere poles with a central twist, which makes the shell unsymmetrical and not complanate as in the type Spiroloculina.

The form known as Sigmoilina (Spiroloculina) tenuis is nearly complanate, outspread, and slightly twisted in sigmoidal fashion. In some specimens the shell is delicate and minute, and completely spiroloculine from end to end. The ultimate chamber is drawn out into a tubular neck, bearing a circular aperture with appendicular tooth.

Distribution.-Cretaceous to Recent. Shallow waters over wide areas in existing oceans. One specimen obtained in the Pleistocene at Santa Barbara, near the hill crest.

\section{Family LITUOLIDÆ.}

\section{Subfamily LITUOLIN A.}

\section{Genus HAPIOPHRAGMIUM.}

\section{Haplophragmium canariense (D'Orbigny).}

\author{
Plate VII, figures $1, \mathrm{a}-\mathrm{h}$.
}

Nonionina canariense D'Orbigny, 1839, Foram. Canaries, p. 128, Pl. II, figs. 33, 34. Nonionina jeffreysii Williamson, 1858, Recent Foram. Great Britain, p. 34, Pl. III, figs. $72,73$.

Haplophragmium canariense Brady, 1884, Challenger Rept., vol. 9, p. 310, PI. XXXV, figs. 1-5.

Haplophragmium canariense Goes, 1894, Kongl. Svenska Vetenskaps-Akad. Handl., Bd. 25, No. 9, p.'20, Pl. V, figs. 92-101.

Description. -Test dark brown or gray, because of its arenaceous character; nautiloid, laterally compressed with nearly flush umbilici; segments rather numerous (in San Pedro type there are 10 in the final whorl); septal lines slightly depressed, straight or nearly so, chambers a little inflated, but in a few specimens scarcely distinct; periphery 
broadly rounded; aperture a narrow slit on inner margin of final chamber, which has a rounded bulbous septal face.

Distribution.-Pliocene to Recent. This species does not seem to have been hitherto recorded from Pliocene deposits, but it has been obtained in a number of post-Tertiary formations, especially those of Norway, Ireland, and Scotland, and is of world-wide distribution to-day. It inhabits the cold shallow north Atlantic waters and is less common at great depths.

One specimen was found in the Pliocene beds of San Pedro.

SubfamHy TROCHAMMININ $A$.

Genus Trochammina.

Trochammina trullissata Brady.

Plate VII, figures 2, a, b.

Trochammina trullissata Brady, 1879, Quart. Jour. Micr. Sci., vol. 19, new ser., p. 56, Pl. V, figs. 10, 11.

Trochammina trullissata Brady, 1884, Challenger Rept., vol. 9, p. 342, Pl. XL, figs. 13-16.

Description. - Brady describes this species as follows:

Test spiral, nautiloid; compressed, lenticular, somewhat excavated at the umbilici; composed of about three convolutions, the last of which often almost entirely incloses those preceding it; peripheral edge acute or rounded. Segments numerous, about nine in the later convolutions; the sutures marked externally by slightly excavated sinuate lines. Exterior smooth and glossy; interior surface often punctate or reticulate; color brown. Aperture crescentiform; situated on the face of the terminal chamber, close to the margin of the previous convolution.

The three specimens of the genus Trochammina from the Pliocene of San Pedro correspond closely to the above description.

Distribution. - Three specimens were found in the Pliocene beds of San Pedro. The species is typically Recent. Brady records the form from some 25 localities in the north and south Atlantic, south Pacific, and Indian oceans, most of which were at great depths $(1,500$ to 2,000 fathoms).

Family TEXTULARIIDA.

\section{SubPamily TEXTULARIINA.}

Genus TEXTULaria.

Textularia abBreviata D'Orbigny.

Plate VII, figures 6 , a-c, 7 , a-c.

Textularia abbreviata D'Orbigny, 1846, Foram. foss. Vienne, p. 249, Pl. XV, figs. 9-12 (error for 7-12).

Textularia abbreviata Brady, Parker, and Jones, 1888, Trans. Zool. Soc. London, vol. 12, pt. 7, p. 219, Pl. XLII, figs. 4, 5 (fig. 4 shows fistulose condition).

Description.-Test similar to Textularia agglutinans D'Orbigny but shorter and with fewer segments. It has the outline of $T$. gramen 
D'Orbigny, but the lateral margins are angular, not rounded. The form is broader than T. agglutinans, seems to be composed of more minute grains, and is probably more calcareous in its cementing material. A single specimen with seven and eight segments, which was obtained at San Pedro, seems to belong to this species.

Distribution.-Miocene of the Vienna Basin; Pliocene of San. Pedro (rare); Recent, Abrolhos Bank and off Brazil, usually in the fistulose state (Brady, Parker, and Jones, loc. cit.).

\section{Textularia agglutinans D'Orbigny.}

Plate VII, figures $3, a, b, 5$, a-c.

Textularia agglutinans D'Orbigny, 1839, Foram. Cuba, p. 144, Pl. I, figs. 17, 18, 32-34. Textularia agglutinans Brady, 1884, Challenger Rept., vol. 9, p. 363, Pl. XLIII, figs. 1-3; varieties, figs. 4 and 12 .

Textularia agglutinans Goes, 1894, Kongl. Svenska Vetenskaps-Akad. Handl., Bd. 25, No. 9, p. 35, Pl. VII, figs. 281-284, 294-303.

Textularia agglutinans Jones, 1895, Foram. Crag, pt. 2: Paleont. Soc., vol. 49, pp. 147-149, Pl. III (1866), figs. 14-16.

Description.-Textularia agglutinans, because of its arenaceous character, belongs to the genus Plecanium of Reuss. This form is the most common of all the Textularia, whether recent or fossil, and is known in strata as early as the Lower Cretaceous. The form is typical for Textularia, being elongate and biserial, with nearly horizontal, narrow, rather numerous segments, somewhat depressed along septal lines, and the shell wall consisting of agglutinated sand grains passing into some calcareous cementing material in the deep-water types. The periphery is never acutely angular, and the form never becomes entirely calcareous, as does Textularia sagittula Defrance. It is well known as a Cretaceous fossil and is common in Tertiary deposits, but inasmuch as it is characteristic of sandy or silty bottoms it is not typically developed in fine calcareous deposits. In the tropical coral reefs the species is much elongated, and is considered a variety, T. agglutinans var. porrecta Brady.

Distribution.-Cretaceous to Recent. Not common in the Pliocene of San Pedro, for the deposits are not very favorable for Textularia.

\section{Textularia sagittula Defrance.}

Plate VIII, figures $1,2, a-c$.

Textularia sagittula Defrance, 1824, Dict. sci. nat., vol. 32, p; 177; vol. 53, p. 344; Atlas Conchol., Pl. XIII, fig. 5.

Textularia nusdorfensis D'Orbigny, 1846, Foram. foss. Vienne, p. 243, Pl. XIV, figs. 17-19.

Textularia sagittula Jones, 1895, Foram. Crag, pt. 2: Paleont. Soc., vol. 49, p. 142, Pl. III (1866), figs. 7-9; Pl. V, figs. 15, 16, 18.

Description.-This is one of the most abundant of all Textularia both living and fossil, and like many other variable types has been 
described under a large number of names. The form is narrow, elongate, strongly compressed, and with sharp-angled margins. The chambers are numerous, some specimens having 12 to 15 . They are closely set and are separated by nearly straight, slightly oblique septal lines, or by lines curving a little toward the center. The aperture is central and subterminal.

Distribution.-This form inhabits, for the most part, shallow waters of temperate zones, but occurs at all depths down to 2,700 fathoms. It is especially characteristic of Cretaceous and Tertiary deposits, but is rare in the Pliocene of San Pedro.

\section{Genus GAUDRYINA.}

\section{GaUdRYina PUPOIDEs D'Orbigny.}

\section{Plate VIII, figures 3-8.}

Gaudryina pupoides D’Orbigny, 1840, Mém. Soc. géol. France, vol. 4, p. 44, P1. IV, figs. 22-24.

Gaudryina pupoides D'Orbigny, 1846, Foram. foss. Vienne, p. 197, Pl. XXI, figs. 34-36. Gaudryina pupoides Brady, 1884, Challenger Rept., vol. 9, p. 378, PI. XLVI, figs. 1-4. Gaudryina pupoides Flint, 1899, Recent Foram.: Rept. U. S. Nat. Mus. for 1897, p. 287, pl. 32, fig. 4 .

Description.-The delicate-shelled dimorphous Gaudryina so well developed in the Cretaceous is an easily recognized species. The triserial portion of the shell extends about one-fourth or one-fifth of the total length and is succeeded by textularian, slightly inflated chambers, the final one carrying the aperture at its inner margin. The species is likely to be mistaken for Textularia agglutinans unless the initial triserial character is visible. Recent specimens are thinshelled calcareous forms with smooth surface. Fossil types have a roughened exterior, are larger, and are less symmetrically constructed.

Distribution.-Chiefly a Cretaceous form but occurs in all succeeding formations. One specimen was recognized in the lower series and another in the upper series of the Pleistocene at Santa Barbara. The species is considered characteristically a deep-water form, but it occurs over wide areas and at varying depths.

\section{GaUdRYina RUgosa D'Orbigny.}

\section{Plate VII, figures 4, a, b.}

Gaudryina rugosa D’Orbigny, 1840, Mém. Soc. géol. France, vol. 4, p. 44, Pl. IV, figs. $20,21$.

Gaudryina rugosa Reuss, 1855, Sitzungsber. Akad. Wiss. Wien, vol. 18, p. 244, Pl. VI, fig. 61 .

Description.-The triserial portion of this species is trihedral, a feature which, with the rough arenaceous character of the shell walls, serves as a ready means of identification. 
Distribution.-Upper Cretaceous to Recent. Like Gaudryina pupoides, it is best known as a Cretaceous and Tertiary fossil, but it occurs to-day in scattered localities at various depths down to 675 fathoms. A single specimen was obtained from the Pleistocene beach bluffs at Santa Barbara.

\section{Subfamily BULIMININ $A$.}

\section{Genus BULIMINA.}

Bulmina CONTRaRia (Reuss). .

Plate IX, figure 2.

Rotalina contraria Reuss, 1851, Zeitschr. Deutsch. geol. Gesell., vol. 3, p. 76, Pl. V, fig. 37.

Ataxophragmium simile Karrer, 1868, Sitzungsber. Akad. Wiss. Wien, vol. 57, p. 126,

Pl. I, fig. 1.

Bulimina contraria Brady, 1884, Challenger Rept., vol. 9, p. 409, Pl. LIV, fig. 18.

Description.-This species resembles so closely in its general appearance certain Rotalina forms that it may easily be confused with such types as Pulvinulina auricula, but its aperture and growth are distinctly buliminine.

Distribution.-Oligocene (Septaria clays) to Recent. The species was dredged at only nine stations by the Challenger. One of these was from the north Atlantic at 1,070 fathoms, one from the siliceous sponge (Hyalonema) ground off Japan, and the others from the south Pacific, at depths ranging from 17 to 1,350 fathoms.

The Pliocene sands of San Pedro contain a few forms of Bulimina referable to this type, but they are very minute and may be easily overlooked among the larger Foraminifera.

\section{Bulimina convoluta Williamson.}

\section{Plate IX, figures $3, \mathrm{a}, \mathrm{b}$.}

Bulimina pupoides var. convoluta Williamson, 1858, Recent Foram. Great Britain, p. $63, \mathrm{Pl}$. V, figs. 132,133 .

Bulimina convoluta Brady, 1884, Challenger Rept., vol. 9, p. 409, PI. CXIII, fig. 6.

Description.-Test obscurely rotaliform, turreted, oval, and unequally compressed laterally. A suggestion of biserial arrangement appears in the peculiar inset segment arrangement toward the distal end. Williamson's original figures do not reveal the segmentation, but it is shown by the plate in the Challenger report. The longer diameter of the San Pedro specimen measures 0.75 millimeter.

Distribution.-Pliocene of San Pedro (very rare); Recent, dredged by the Challenger only in Torres Strait, at 155 fathoms. Williamson's specimens came from Shetland. 


\section{Bulimina elegantissima D'Orbigny.}

Plate IX, figures 8, a-c.

Bulimina elegantissima D'Orbigny, 1839, Foram. Amérique mérid., p. 51, Pl. VII, figs. 13, 14.

Bulimina elegantissima Williamson, 1858, Recent Foram. Great Britain, p. 64, Pl. V, figs. 134, 135.

Bulimina elegantissima Bagg, 1905, Bull. U. S. Geol. Survey No. 268, p. 21, Pl. II, fig. 4.

Description.-Test regularly spiral, consisting of two or three convolutions, the last of which constitutes more than three-fourths of the entire shell. The final whorl has from seven to ten segments, which are long axially but narrow and obliquely set and with sutures only slightly depressed. The species is very minute. Only one specimen was discovered in the Pliocene of San Pedro.

\section{Bulimina ovata D'Orbigny.}

Plate IX, figures 6, a, b.

Bulimina ovata D'Orbigny, 1846, Foram. foss. Vienne, p. 185, PI. XI, figs. 13, 14. Bulimina ovata Ḅagg, 1905, Bull. U. S. Geol. Survey No. 268, p. 22, Pl. III, fig. 1.

Description.-Three species of Bulimina, B. ovata, B. pupoides, (Pl. IX, figs. 5, a, b) and $B$. affinis, are very closely related, similar in outline, and difficult to distinguish. All three forms were originally described by D'Orbigny, and they might well be considered varieties of one species were not the general types depending on their outlines so well established. Means of distinguishing them are shown in the following table:

Characteristics of similar species of Bulimina.

\begin{tabular}{|c|c|c|c|}
\hline Specles. & Initial end. & Distal extremity. & General outline. \\
\hline 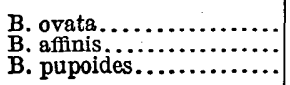 & 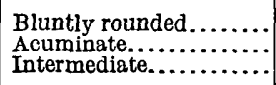 & $\begin{array}{l}\text { Broadly oval............. } \\
\text { Obovate................. } \\
\text { Less regular.......... }\end{array}$ & $\begin{array}{l}\text { Ovate. } \\
\text { Obtusely ovate. } \\
\text { Chambers projecting. }\end{array}$ \\
\hline
\end{tabular}

The apertures of these forms are similar, but they differ somewhat in segmentation and in the relative size of the chambers. The figures here copied from Brady's monograph (Challenger report) best illustrate the characteristic features of the three varieties.

Distribution.-Bulimina ovata ranges from Eocene to Recent. It is common in the shore sands of the British Isles, and has in general wide geographic and bathymetric range.

It is the most common form of Bulimina found at San. Pedro in the Pliocene. No attempt has been made to distinguish the two allied species described above, though both are probably present. 


\section{Bulimina pYrula D'Orbigny.}

Plate IX, figures $1, a-\theta, 4, a, b$.

Bulimina pyrula D'Orbigny, 1846, Foram. foss. Vienne, p. 184, PI. XI, figs. 9, 10. Bulimina pyrula Brady, 1884, Challenger Rept., vol. 9, p. 399, Pl. I, figs. 7-10.

Bulimina pyrula Flint, 1899, Recent Foram.: Rept. U. S. Nat. Mus. for 1897, p. 290,

Pl. XXXVI, figs. 4 and 5 (by transmitted light).

Description.-Test elongate, ovate, very slightly compressed; shell walls thin and transparent in recent specimens; perforations of shell very fine but distinct, segments erect, overlapping, and often showing externally only three in the mature form. The aperture is generally ovate, with prominent epistomium.

The specimens figured by Flint measure about 1 millimeter and came from Atlantic dredgings at depths of 194 to 1,356 fathoms.

Distribution.-Upper Triassic (?), Eocene (London clay), Miocene (Vienna Basin), Pliocene at San Pedro (several specimens), and Pliocene of southern Italy, but not recognized in the English Crag. The type is especially well developed in the north Atlantic, as are many of these California coast species.

\section{Bulimina subteres Brady.}

Plates IX, figures 7, a-d; XI, figures 1-5.

Bulimina subteres Brady, 1884, Challenger Rept., vol. 9, p. 402, Pl. L, figs. 20-22.

Bulimina subteres Goes, 1894, Kongl. Svenska Vetenskaps-Akad. Handl., Bd. 25, No. 9 , p. 46, P1. IX, figs. $445-453$.

Description.-Brady's description of this species follows:

Test elongate-ovate, tapering to a blunt point at the initial extremity, rounded at distal end; consisting of from two to three more or less regular oblique convolutions. Chambers relatively large and only slightly ventricose externally; sutural lines very distinct. Aperture a curved slit near the inferior umbilical margin of the terminal chamber, considerably removed from the distal end of the test.

The above is the original description of this species, which, so far as the writer is aware, has not been recognized in fossil form heretofore. The form is closely related to Bulimina elegantissima D'Orbigny on the one hand and to Bulimina (Robertina) arctica D'Orbigny on the other.

Distribution.-Pleistocene of Santa Barbara (rare) and Recent. According to Brady the species has a wide geographic range and is found in the Arctic waters of the north Atlantic as far north as latitude $83^{\circ} 19^{\prime}$. 


\section{Genus BOIIVINA.}

\section{Bolivina BEYRICHI Reuss.}

Plate X, figure 10 .

Bolivina beyrichi Reuss, 1851, Zeitschr. Deutsch. geol. Gesell., vol. 3, p. 83, PI. VI, fig. 51.

Bolivina beyrichi Brady, 1884, Challenger Rept., vol. 9, p. 422, Pl. III, fig. 1.

Description.-Test strongly compressed, narrow, elongate, textulariform; margins acute, each segment projecting downward at the periphery into a spinous point. These spines are more extended above, and less prominent toward the initial segment. The species is not far removed from Vulvulina gramen D'Orbigny. ${ }^{1}$

Distribution.-Oligocene (Septaria cläys of Germany); upper Tertiary of Rome; Pliocene of San Pedro; Recent, off the Canaries at 600 and 1,125 fathoms, off Sydney at 410 fathoms, off Ki Islands at 129 fathoms, and off the Philippines at 95 fathoms (Brady, loc. cit.).

\section{Bolivina beYrichi Reuss var. alata Seguenza.}

Plate $X$, figures 7-9.

Vulvulina alata Seguenza, 1862, Atti Accad. Gioenia sci. nat., 2d ser., vol. 18, p. 115, Pl. II, fig. 5.

Bolivina beyrichi var. alata Terrigi, 1880, Atti Accad. Pont. Nuovi Lincei, vol. 33, p. 198, Pl. II, figs. 43-45.

Bolivina beyrichi var. alata Brady, 1884, Challenger Rept., vol. 9, p. 422, Pl. LIII, figs. 2-4.

Description.-This is a variety of Bolivina beyrichi having a peripheral wing or keel of variable form and dimensions. It is proportionally broader than Bolivina beyrichi and occurs, whether recent or fossil, usually with the type.

Distribution.-Oligocene to Recent. Dredged by the Challenger at a few stations in shoal waters in the Pacific.

Occurs in the Pliocene at Timms Point, San Pedro, but is not common.

\section{Bolivina dilatata Reuss.}

Plate XI, figures 7-9.

Bolivina dilatata Reuss, 1849, Denkschr. Akad. Wiss. Wien, vol. 1, p. 381, Pl. XLVIII, fig. 15.

Bolivina dilatata Brady, Parker and Jones, 1888, Trans. Zool. Soc. London, vol. 12, pt. 7, p. 221, P1. XLIII, figs. 3, 6 .

Bolivinia dilatata, Bagg, 1905, Bull. U. S. Geol. Survey No. 268, p. 24, III, fig. 4.

Ilescription.-Test broadly expanded at interior end, tapering gradually to narrow posterior extremity. Lateral margins acute; 
segments numerous, arranged symmetrically, textulariform; coarsely punctate, varying much in size and outline.

Distribution.-Miocene to Recent. Exists to-day in the north Atlantic in dredgings at all depths to 1,180 fathoms.

Rare in Pliocene at San Pedro.

\section{Bolivina noBILIS Hantken.}

Plate $\mathrm{X}$, figures 6 , a-c.

Bolivina nobilis Hantken, 1875, Mittheil. Jahrb. Ung. geol. Anstalt, vol. 4, p. 65, Pl. XV, fig. 4 .

Bolivina nobilis Brady, 1884, Challenger Rept.; vol. 9, p. 424, Pl. LIII, figs. 14, 15.

Description.-Test similar to Bolivina punctata but more stoutly built. The surface is covered with fairly numerous parallel vertical striations. According to Brady, the fossil ornamentation is less distinct than in the recent forms, but the writer has none of the latter for comparison. Length, 0.87 millimeter.

Distribution.-At the present day the species seems to be confined to shoal waters of the south Pacific. It was dredged off Port Jackson at 6 fathoms; off Fiji at 25 fathoms, etc. The original specimens came from the Clavulina-Szaboi formation of Hungary. The species is very rare in the Pliocene of San Pedro, most of the Bolivina species found there being without ornamentation.

\section{Bolivina punctata D'Orbigny.}

Plate X, figures 1-5.

Bolivina punctata D'Orbigny, 1839, Foram. Amérique mérid., p. 63, Pl. VIII, figs. $10-12$.

Bolivina antiqua D'Orbigny, 1846, Foram. foss. Vienne, p. 240, P1. XIV, figs. 11-13. Bolivina punctata Bagg, 1898, Bull. U. S. Geol. Survey No. 88, p. 33, Pl. II, fig. 3. Bolivina punctata Bagg, 1905, Bull. U. S. Geol. Survey No.268, p. 24, Pl. III, fig. 6.

Description.-The test of Bolivina punctata is slender and narrowelongate, strongly compressed, textulariform, and finely perforate. The ultimate end is obtuse; the posterior is tapering and rather acute, and the lateral margins are subcarinate. The number of chambers is variable, but typical specimens show from five to ten in each series.

Distribution.-Cretaceous to Recent. The species is common in the New Jersey Cretaceous (Monmouth formation), less common in the California Miocene, where the specimens are very slender and delicate, and rare in both the Pliocene and the Pleistocene deposits of the west coast. Very rare in the Pliocene of San Pedro, and only a few specimens have been found in the Pleistocene of Santa Barbara. 


\title{
Bolivina robusta Brady.
}

\author{
Plate X, figures 11-13.
}

Bolivina robusta Brady, 1881, Quart. Jour. Micr. Sci., vol. 21, new ser., p. 57. Bolivina robusta Brady, 1884, Challenger Rept., vol. 9, p. 421, Pl. LIII, figs. 7-9.

Description.-Brady gives the following description of this species:

Test regularly textularian; elongate, compressed; broad and rounded at the oral extremity; tapering to a point, and frequently terminating in a long, stout spine at the aboral end. Test thickest on the median line and sloping away symmetrically toward the lateral edges; margin subacute. Segments numerous, about 10 in each series, long, curved, obliquely set. Shell stoutly built, sutures thickened, usually limbate and somewhat crenate externally. *** Length, $\frac{1}{45}$ inch (0.56 millimeter), exclusive of the terminal spine.

Distribution.-Although this species so well described by Brady has been recognized off Norway at shallow depths and in various oceans from shore line down to 1,900 fathoms, it does not appear to be recorded in the fossil condition. Two specimens were obtained from the Pliocene of San Pedro.

\section{Bolivina TeXTILARIOIDEs Reuss.}

Plate XI, figures 6, a, b.

Bolivina textilarioides Reuss, 1862, Sitzungsber. Akad. Wiss. Wien, vol. 46, p. 81, Pl. $\mathrm{X}$, fig. 1.

Bolivina textilarioides Brady, 1884, Challenger Rept., vol. 9, p. 419, Pl. LII, figs. 23-25.

Description.-Test narrow, elongate; margins rounded; finely punctate, with close resemblance to Textularia agglutinans D'Orbigny, but carrying a Bolivina aperture. Segments short, slightly inflated, a little lobulated at periphery. According to Brady (loc. cit.), the species possesses few segments, but in the writer's opinion the segmentation varies, as in Bolivina punctata, and many specimens may show as many segments as that species.

Distribution.-Cretaceous (North Germany; Matawan formation, New Jersey); Pliocene at San Pedro (rare); Recent, north Atlantic. at 96 to 183 fathoms, south Pacific at 218 to 610 fathoms, north Pacific at 40 fathoms and (at one station) 2,075 fathoms (Brady).

\section{Subfamily CASSIDULININ $\approx$. Genus CASSIDULINA. \\ Cassidulina calabra (Seguenza). \\ Plate XII, figures 1, a-c.}

Burseolina calabra Seguenza, 1879, Formaz. Terz. Reggio, p. 138, PI. XIII, fig. 7. Cassidulina calabra Brady, 1884, Challenger Rept., vol. 9, p. 431, Pl. CXIII, fig. 8.

Description.-Test almost spherical, composed of irregular narrow, angular segments which intersect at different points along the shell 
surface. Septa flush, but the, ultimate segment overlaps and is provided with a countersunk border over the small, nearly circular aperture, which is slightly raised at its edge. The form resembles Cassidulina subglobosa Brady, but the latter has septal depressions between the segments and carries an aperture of different character.

Distribution.-Upper Miocene of Reggio, Calabria; very rare in the Pliocene at San Pedro; found.in Torres Strait at 155 fathoms and also near the Fiji Islands.

\section{Cassidulina crassa D'Orbigny.}

Plate XII, figures 6, a-f.

Cassidulina crassa D'Orbigny, 1839, Foram. Amérique mérid., p. 56, Pl. VII, figs. 18-20.

Cassidulina crassa D'Orbigny, 1846, Foram. foss. Vienne, p. 213, Pl. XXI, figs. 42, 43. Cassidulina obtusa Williamson, 1858, Recent Foram. Great Britain, p. 69, Pl. VI, fige. $143,144$.

Cassidulina crassa Brady, 1884, Challenger Rept., vol. 9, p. 429, Pl. LIV, figs. 4, 5. Cassidulina crassa Goes, 1894, Kongl. Svenska Vetenskaps-Akad. Handl., Bd. 25, No. 9, p. 43, Pl. VIII, figs. 421, 422.

Description.-Test discoidal, oval, with obtusely rounded margin; segments more or less inflated and few in number, usually four or five showing in one aspect. Thicker than Cassidulina lævigata, and the fewer segments are shorter and more tumid. The aperture, a deep crescentic slit beneath the periphery under the ultimate segment, extends back and along the junction of the two final segments.

Distribution.-Miocene of Vienna; Pliocene of England, Italy, and San Pedro, Cal.; rare in the Pleistocene of Santa Barbara. Of worldwide distribution in present seas and recorded at depths ranging from a few fathoms down to 2,760 fathoms in the north Atlantic.

\section{Cassidulina lempigata D'Orbigny.}

Plate XII, figures 3, a, b, 5, a-c.

Cassidulina lævigata D’Orbigny. 1826, Annales des sci. nat., vol. 7, p. 282, No. 1, Pl. XV, figs. 4, 5, modèle 41 .

Cassidulina lævigata Williamson, 1858, Recent Foram. Great Britain, p. 68, Pl. VI, figs. 141, 142.

Cassidulina lævigata Brady, 1884, Challenger Rept., vol. 9, p. 428, Pl. LIV, figs. 1-3. Cassidulina lævigata Goes, 1894, Kongl. Svenska Vetenskaps-Akad. Handl., Bd. 25, No. 9, p. 43, Pl. VIII, figs. 418-420.

Cassidulina lævigata Jones, 1895, Foram. Crag, pt. 2: Paleont. Soc., vol. 49, p. 171: Pl. IV, fig. 15.

Description.-Test lenticular, compressed, with sharp peripheral margin suggesting a carina; segments numerous, strongly curved, slightly inflated; aperture a narrow slit set deeply below the margin of ultimate chamber: The pseudopodal apertures are not uniformly distinct, and according to Jones they vary with the age of the shell. 
It is owing to this feature of variation that Reuss established Cassidulina punctata, which Jones considers a synonym of the present species.

Distribution.-Eocene to Recent. In the Pliocene of San Pedro it is less abundant than C. subglobosa Brady, but in the Pleistocene of Santa Barbara it is extremely abundant. It is common in the littoral zone around Norway and Sweden, and, though not confined to Arctic waters, it is particularly characteristic of cold water. Its bathymetric range is from 60 to 1,675 fathoms.

\section{Cassidulina subglobosa Brady.}

Plate XII, figures 2, a, b, 4.

Cassidulina subglobosa Brady, 1881, Quart. Jour. Micr. Sci., vol. 21, new ser., p. 60. Cassidulina subglobosa Brady, 1884, Challenger Rept., vol. 9, p. 430, Pl. LIV, fig. 17. Cassidulina subglobosa Brady, Parker, and Jones, 1888, Trans. Zool. Soc. Lovdon, vol. 12 , pt. 7, p. 221, Pl. XLIII, figs. 12-14.

\section{Description.-Brady describes this form as follows:}

Test subglobular, somewhat compressed on the two lateral faces, inequilateral; segments few, slightly inflated; alternation irregular. Aperture an oblique or nearly erect looplike slit on the face of the projecting terminal segment.

The shape and position of the aperture and the irregularity of arrangement of chambers separate this species from C'assidulina crassa and C. calabra Seguenza. The forms obtained at San Pedro are very large and robust, and their development is typical, agreeing well with Brady's original description' and figures.

Distribution.-Very abundant in the Pliocene at San Pedro, where Cassidulina is so numerous that were it not for the equal abundance of a few species of Biloculina and Miliolina the deposit might well be characterized as a Cassidulina ooze. In the Pleistocene of Santa Barbara it is extremely abundant in the upper strata and less common in the lower beach formation.

Living specimens were found at Abrolhos Bank, in the north Atlantic, at 260 fathoms and less. The species occurs in the north and south Atlantic and elsewhere and is considered by Brady a deepwater type. Inasmuch as the California deposits were laid down in shallow water it seems probable that the species is cosmopolitan rather than characteristic of deep water. 


\section{Family LAGENID $A$.}

\section{Subfamily LAGENIN A.}

Genus LAGENA.

Lagena acuticosta Reuss.

Plate XIV, figure 28.

Lagena acuticosta Reuss, 1861, Sitzungsber. Akad. Wiss. Wien, vol. 44, p. 305, Pl.I. fig. 4.

Lagena acuticosta Reuss, 1862, Sitzungsber. Akad. Wiss. Wien, vol. 46, p. 331, Pl. V. fig. 63.

Lagena acuticosta Brady, Parker, and Jones, 1888, Trans. Zool. Soc. London, vol. 12, pt. 7, p. 222, Pl. XL̂IV, figs. 26, 31.

Description.-Test similar to all types of Lagena sulcata, but with only a few (12 to 14) prominent sharp ribs extending over the entire surface. The form is usually stout and larger than its congener and is without tubular extension.

Distribution.-Lower Cretaceous to Recent. Rare in present oceans and lives at a great depth (2,425 fathoms), where a temperature of approximately $1^{\circ} \mathrm{C}$. prevails. Several specimens were found in the Pliocene at San Pedro, and one in the Pleistocene of Santa Barbara.

\section{Lagena DENTALIFormis n. $\mathrm{sp}$.}

Plate XIII, figures 1, a, b, 2, a, b.

Several slender, semitransparent specimens of Lagena from the Pliocene of San Pedro seem to be new. The test is very attenuate and arcuate, with tapering extremities, as in Lagena elongata Ehrenberg. All the specimens are rather symmetrically and gently curved and therefore the term Lagena dentaliformis is suggested.

The best preserved specimens measure 2.5 millimeters in length. A slight indentation at one point in the shell in two specimens is possibly accidental. The form is not abundant.

A figure of Lagena gracillima (Seguenza) in the monograph on the Foraminifera of the $\mathrm{Crag}^{1}$ corresponds closely with the configuration of these San Pedro specimens. The type of L. gracillima is, however, straight and more bulbous in the center. It seems bast to refer all tentative forms to a new species. 
Lagena elongata (Ehrenberg).

Plate XIII, figures 4, a, b.

Miliola elongata Ehrenberg, 1844, Ber. K. preuss. Akad. Wiss. Berlin, p. 274; idem, 1845, p. 371; fig. in Mikrogeologie, 1854, p. xxv, fig. 1.

Lagena elongata Flint, 1899, Recent Foram:: Rept. U. S. Nat. Mus. for 1897, p. 306, pl. 53, fig. 1.

Description.-This form is very similar to Lagena gracillima except that the body is less bulbous and more attenuate, with a short taper at each extremity.

Distribution.-Lower Jurassic (English Lias); Cretaceous limestones of Antilibanon; Pliocene of San Pedro (rare); Recent, recorded by Brady only in the north Atlantic and south Pacific.

\section{Lagena globosa (Montagu).}

Plate XIII, figures 9 , a-c.

Vermiculum globosum Montagu, 1803, Test. Brit., p. 523.

Entosolenia globosa Williamson, 1858, Recent Foram. Great Britain, p. 8, P1. I, figs. $15,16$.

Lagena globosa Reuss, 1862, Sitzungsber. Akad. Wiss. Wien, vol. 46, Bd. 1, pt. 1, p. 318, Pl. I, figs. 1, 3.

Lagena globosa Goes, 1894, Kongl. Svenska Vetenskaps-Akad. Handl., Bd. 24, No. 9, p. 77 , Pl. XIII, fig. 741.

Lagena globosa Jones, 1895, Foram. Crag, pt. 2: Paleont. Soc., vol. 49, p. 177, Pl. I

(1866), fig. 32.

Description.-This is one of the simplest of all Foraminifera. The test is oval, globular or subglobular, elliptical, pyriform, smooth, and hyaline; the aperture is in an entosolenian neck. Some types are broadly rounded at the base, and others are narrow, but there is no prolongation anteriorly into a tubular neck as in Lagena vulgaris (Williamson). The aperture is circular, radiate central. This species is similar to Lagena apiculata, but is without distal spine. It has been described under a number of different specific terms, a very exhaustive list of which is given in the Crag monograph above cited.

Distribution.-This is one of the 'most common Lagenidæ, recent or fossil. It occurs in all seas, at all depths, and in arctic and tropical waters.

Prof. H. B. Brady records this species from the Upper Silurian. It occurs in the Oolite (Terquem) and in every succeeding formation. Several specimens were found in the Pleistocene at Santa Barbara, near the crest of the hill. 


\section{Lagena gracilis Williamson。}

Plate XIV, figures 7, 8, a, b.

Lagena gracilis Williamson, 1848, Annals and Mag. Nat. Hist., 2d ser., vol. 1, p. 13, Pl. I, fig. 5.

Lagena vulgaris var. gracilis Williamson, 1858, Recent Foram. Great Britain, p. 7, Pl. I, figs. 12, 13.

Lagena gracilis Jones, 1895, Foram. Crag, pt. 2: Paleont. Soc., vol. 49, p. 189, Pl. VII, fig. 6.

Description.-Test elongate, flask-shaped, somewhat tapering or apiculate below, provided with long or short neck above. Surface marked by a few or by many longitudinal striations or costæ. Jones figures a form with six prominent costæ. The species describerl in this report as new (Lagena sesquistriata) differs from the above in the nonapiculate and broad base and in the shorter anterior end. It may be that the specimens obtained by the writer are only varieties of this species, but they seem to be distinct.

Distribution.-Found in the Folkestone Gault and the Upper Cretaceous of England. Recorded also in the Eocene, Oligocene, Pliocene, and Pleistocene. Several specimens were taken from the upper strata of the Pleistocene at Santa Barbara.

\section{Lagena grachllima (Seguenza).}

Plate XIII, figure 3.

Amphorina gracillima Seguenza, 1862, Foram. Monta. Messina, p. 51, PI. I, fig. 37. Lagena sulcata var. distoma-polita Parker and Jones, 1865, Philos. Trans., vol. 155, p. 357, Pl. XIIİ, fig. 21; Pl. XVIII, fig. 8.

Lagena gracillima Brady, 1884, Challenger Rept., vol. 9, p. 456, Pl. LVI, figs. 19-28.

Description.-The test of Lagena gracillima consists of a very long attenuated tube drawn into constricted apertures at each extremity. The surface is perfectly smooth, hyaline, and glistening. The tube is typically straight and has its largest diameter near the center. Some specimens are bulbous, and these have long extensions at each end. Two specimens from the Pliocene of San Pedro which belong to this species are more dentaline than the figures given in the Challenger report. The figures given by Jones, Parker, and Brady in the Crag monograph ${ }^{1}$ do not check with other published types. This reference is therefore placed here under Lagena dentaliformis, a new species (p. 45).

Distribution.-Miocene; especially . abundant in the Pliocene; Pleistocene of Norway; very widespread to-day at all depths.

1 Paleont. Soc., vol. 19, 1866, Pl. I, figs. 36, 37.

$45625^{\circ}-$ Bull. $513-12-4$ 
LAgena LAivis (Montagu).

Plates XIII, figures 5-8; $\mathbf{k}, 10,11, a, b ; X I V$, figures 23, 24.

Vermiculum læve Montagu, 1803, Test. Brit., p. 524.

Lagena vulgaris Williamson, 1858, Recent Foram. Great Britain, p. 4, Pl. I, fig. 5. Lagena lavis Brady, 1884, Challenger Rept., vol. 9, p. 455, PI. LVI, figs. 7-14, 30.

Lagena lævis Bagg, 1908, Proc. U. S. Nat. Mus., vol. 34, p. 141.

Description.-Test subglobular, pyriform, oval, or flask-shaped, always possessing a long tubular neck at anterior end. The surface is smooth and white. This is one of the oldest known Foraminifera, for it occurs in upper Silurian deposits. Owing to its variable form it has been described under a large number of terms, especially under Lagena vulgaris (Williamson).

Distribution.-Upper Silurian (Wenlock limestone, Brady); basal Lower Jurassic (Lower Lias, Yorkshire, Blake); Lower and Upper Cretaceous of England and in succeeding formations. It is very abundant in the Pliocene at Timms Point, San Pedro, but exceedingly rare in the Pleistocene of Santa Barbara.

The species is widely distributed and is not restricted in depth at the present day. In dredgings off the Hawaiian Islands it was observed by the writer only in material from one station, at 689 fathoms. It inhabits the cold waters of Greenland and Spitzbergen at moderate depths.

\section{Lagena lagenoides (Williamson).}

Plate XIV, figures 25, 26.

Entosolenia marginata var. lagenoides Williamson, 1858, Recent Foram. Great Britain, p. 11, Pl. I, figs. 25, 26.

Lagena apendiculata (Williamson) Reuss, 1862, Sitzungsber. Akad. Wiss. Wien, vol. 46, p. 324, Pl. II, figs. 27, 28.

Lagena lagenoides Brady, 1884, Challenger Rept., vol. 9, pp. 447, 479, Pl. LX, figs. 6, 7, $9,12-14$.

Lagena lagenoides Jones, 1895, Foram. Crag, pt. 2: Paleont. Soc., vol. 49, p. 201, Pl. I (1866), figs. 29-31.

Description.-The periphery of Lagena lagenoides is provided with a laminar ring of variable width. The shell is oval, pyriform, and biconvex. The anterior end is prolonged and tubular and carries the ectosolenian neck, which is in a few specimens maintained within the tube as an entosolenian chamber. This winglike border is traversed by minute tubuli which radiate from the inner margin toward the periphery, a characteristic feature which affords a ready means of recognizing the species.

Distribution.-Miocene (Messina), Pliocene (Crag), and Pleistocene (Canada). Rare in the upper strata of the Pleistocene at Santa Barbara. It is said to be common off British coasts, more abundant 
in the north Atlantic, and less abundant in the south Atlantic and south Pacific. Its bathymetric range is from 38 to 2,740 fathoms (Jones).

\title{
Lagena marginata (Walker and Boys).
}

\author{
Plate XIV, figures 18, a-c, 21, a, b. 22, a, b.
}

- Serpula (Lagena) marginata Walker and Boys, 1784, Test. Min., p. 2, Pl. I, fig. 7.

Entosolenia marginata Williamson, 1858, Recent Foram. Great Britain, p. 9, Pl. I, figs. 19-21.

Description.-Test compressed, typically oval in outline, furnished with depressed carinate or winglike border, and possessing an entosolenian orifice. In some specimens the encircling peripheral margin is widely extended into a wing, which is thin and easily worn off in fossil shells. The species is typical of compressed lenticular Lagena with carinate margin. Some of the specimens obtained at San Pedro are large for the genus (0.75 millimeter).

Distribution.-Lower Cretaceous to Recent. Very common in the Pliocene of San Pedro and in all the strata of the Pleistocene of Santa Barbara. Found to-day in all latitudes and at all depths, down to 3,125 fathoms.

\section{Lagena melo (D'Orbigny).}

Plate XIV, figures 16-17.

Oolina melo D’Orbigny, 1839, Voyage Amérique mérid., vol. 5, pt. 5, Foraminifères, p. 20, Pl. V, fig. 9 .

Lagena melo Jones, 1895, Foram. Crag, pt. 2: Paleont. Soc., vol. 49, p. 191, Pl. I (1866), fig. 35. (Surface structure diagrams on p. 192.)

Description.-The most variable features of surface ornamentation are found among Lagenidæ. In this species, which is subglobular and ovate, the surface is crossed by ridges that make rectangular figures, largest near the center of test and becoming triangular at extremities. A form similarly ornamented is Lagena hexagona Williamson, but in that species the raised ornamentation is hexagonal. In Lagena squamosa the ornamentation is similar, but the inclosures are more or less oval and rounded. The forms are very minute, and the ornamentation is made out only with difficulty, specially in fossil forms.

Distribution.-Eocene (London clay); Miocene (Italy); Pliocene (English Crag); Pleistocene (Santa Barbara, abundant). Living in cold waters of the north Atlantic and Arctic oceans, and off the British coasts. D'Orbigny's specimens came from the littoral sands of South America. 


\section{LAGENA QUADRATA (Williamson).}

Plate XIV, figures 19, a, b, 20.

Entosolenia marginata var. quadrata Williamson, 1858, Recent Foram. Great Britain, p. 11, Pl. I, figs. 27, 28.

Lagena quadrata Jones, 1895, Foram. Crag, pt. 2: Paleont. Soc., vol. 49, p. 198, Pl. VII, fig. 9.

Description.-Test compressed, elongate, quadrate in outline, with entosolenian neck. Anterior obtuse, with stoutly projecting orifice but not prolonged into definite tubular neck. Posterior bluntly rounded, in some specimens winged. Peripheral margin bordered by flange, which shows some variation in width, regularity of border, and thickness.

The species is near Lagena seguenziana Fornasini and $L$. læevigata.

The outline, like a parallelogram, and the short anterior end and bordered periphery serve as ready means of distinguishing it.

Distribution.-Miocene and Pliocene of Italy; Pliocene Crag of England; Pleistocene of Ireland; not uncommon in the Pleistocene of Santa Barbara, especially in the upper strata. Recent, limited to very shallow waters. Williamson's specimens came from the British coasts.

\section{Lageña semistriata Williamson.}

Plate XIV, figures 1-5.

Lagena striata var. semistriata Williamson, 1848, Annals and Mag. Nat. Hist., 2d ser., vol. 1, p. 14, Pl. I, figs. 9, 10

Lagena vulgaris var. semistriata Williamson, 1858, Recent Foram. Great Britain, p. 6, Pl. I, fig. 9.

Lagena semistriata Brady, 1884, Challenger Rept., vol. 9, p. 465, Pl. LVII, figs. 14, 16, 17 (and 18?).

Description.-Flask-shaped, with tubular neck of variable length; ornamented with well-defined costæ, which extend only a short distance from the base up over the globular portion of the shell. Posterior extremity typically broad, truncate, carrying ribs from above downward.

Distribution.-Oligocene to Recent. One specimen was found near the hill crest in the Pleistocene of Santa Barbara, Cal. It is widely distributed at the present day, usually at shallow depths, though it occurs at depths of 3,125 fathoms. Inasmuch as the bottom temperatures of the waters dredged by the Challenger were $1^{\circ} \mathrm{C}$., the type is to be regarded as a cold-water species: It is seldom recorded in fossil state.

\section{LAGENA SESqUistriata $n$. $\mathrm{sp}$.}

Plate XIII, figures 12-14, $\mathrm{b}$.

Description.-Test oblong, extended into tubular neck at anterior extremity. Basal and truncate, not acuminate as in Lagena gracilis. 
Costæ typically six prominent elevations extending to the end of the constriction which forms the tubular neck. One form which seems to belong to this species has a shorter, more obtuse outline, and the ribs are more prominent and broader. The form which the writer regards as the type of this species resembles Lagena vulgaris var. perlucida Williamson, ${ }^{1}$ but in the latter the surface costæ are of unequal length and are not continuous over the whole shell, and there is no sharp constriction at the commencement of tubular extension anteriorly.

The type specimen has a greater diameter of 0.55 millimeter. Two specimens were obtained in the Pliocene of San Pedro.

\section{Lagena squamosa (Montagu).}

Plate XIV, figure 27.

Vermiculum squamosum Montagu, 1803, Test. Brit., p. 526, Pl. XIV, fig. 2.

Entosolenia squamosa Williamson, 1858, Recent Foram. Great Britain, p. 12, P1. I, fig. 29.

Lagena squamosa Brady, 1884, Challenger Rept., vol. 9, p. 471, PI. LVIII, figs. 28-31.

Description.-Test nearly spherical, minute; surface covered with reticulated network which shows elongate oval depressions between raised lines.

Distribution.-The species is most common in cold-water zones and at shoal depths, though it has been obtained from depths of 2,300 fathoms in the north Pacific. As a fossil, it goes back to the Eocene and is present in every succeeding deposit. It occurs in the English Crag, in the St. Erth beds, and in the Pliocene of Belgium. It is rare in the Pliocene of San Pedro, and only a single specimen from the upper beds was found in the Pleistocene of Santa Barbara.

\section{Lagena striata (D'Orbigny).}

Plate XIV, figure 6.

Dolina striata D'Orbigny, 1839, Foram. Amérique mérid., p. 21, Pl. V, fig. 12.

Lagena vulgaris var. substriata Williamson, 1858, Recent Foram. Great Britain, p. 7, Pl. I, fig. 14.

Lagena striata Brady, 1884, Challenger Rept., vol. 9, p. 460, Pl. LVII, figs. 19, 22, 24, $28,29,30$.

Lagena striata Jones, 1895, Foram. Crag, pt. 2: Paleont. Soc., vol. 49, 1895, p. 184, Pl. I (1.866), figs. 38, 39; Pl. VII, fig. 8.

Description.-Shell beautifully oval, with tubular neck; often considerably elongated. Surface marked by long, delicate parallel strix, much more numerous and more delicate than those of Lagena sulcata. Forms of Lagena with striate surface show very marked variation. Reduction of the striations and deepening of the zones between them gives rise to sulcate types belonging to another species. 
Distribution.-This form has a very wide distribution at the present day, but is most abundant in the shallow waters of the Arctic, and Antarctic oceans. Near the Tropics the species occurs only at considerable depths, and in one place it has been found at 2,740 fathoms. Its earliest geologic occurrence is in the Eocene (London clay). It is abundant in the Pleistocene of Santa Barbara.

\title{
Lagena striatopunctata (Parker and Jones).
}

\author{
Plate XIV, figures 13-15.
}

Lagena sulcata var. striatopunctata Parker and Jones, 1865. Philos. Trans., vol. 155, p. 350, Pl. XIII, figs. 25-27.

Lagena striatopunctata Goes, 1894, Kongl. Svercka Vetenskaps-Akad. Handl., Bd. 25, No. 9, p. 83, Pl. XIII, fig. 753.

Description.-This bottle-shaped, oval, or pyriform Lagena is characterized by punctation of the costæ, which extend over the entire shell surface. The costæ vary in number from 6 to 20 , and the perforations are either in single or double rows in depressions of the costæ.

Distribution.-The species, though rather rare, is found in Arctic and north Atlantic waters and at shallow depths. Goes's specimens came from Spitzbergen, at a depth of 180 meters.

The form is present in the Septaria clays of Pietzpuhl (Oligocene), and in the post-Pliocene of Scotland and Ireland. Two specimens were taken from the Pleistocene at Santa Barbara, near the hill crest, and two specimens were also found in the Pliocene at San Pedro.

\section{Lagena sulcata (Walker and Jacob).}

Plate XIV, figures 9-12, b.

Serpula sulcata Walker and Jacob, 1798, Adam's Essays, Kanmacher's ed., p. 634, Pl. XIV, fig. 5 .

Lagena vulgaris var. perlucida (pars) Williamson, 1858, Recent Foram. Great Britain, p. 5 , Pl. I, fig. 8 .

Lagena vulgaris var. striata Williamson, idem, p. 6, PI. I, fig. 10.

Entosolenia costata Williamson, idem, p. 6, Pl. I, fig. 18.

Lagena sulcata Brady, 1884, Challenger Rept., vol. 9, p. 462, Pl. LVII, figs. 23, 26, 33, 34. (Apiculate forms, Pl. LVIII, figs. 4, 17, and 18.)

Lagena sulcata Jones, 1895, Foram. Crag, pt. 2: Paleont. Soc., vol. 49, p. 186, PI. I (1866), figs. 40, 41.

Description.-Tést nearly spherical, ovate, pyriform, elongateoval, flask-shaped; surface invariably ornamented with sulcations, above which run parallel costæ the entire length of the shell. When these lines are broken the variety is known as Lagena sulcata var. interrupta Williamson. The number of sulcations is variable, but there are fewer costæ than in L. striata (D'Orbigny). The base is typically rounded and obtuse but in some varieties is apiculate. 
The anterior end shows enough variation to establish several varieties, and this variation, together with the surface modifications, has given rise to a number of synonyms which can best be grouped under one head.

Distribution.-The species is known at all depths, and is of worldwide distribution. It is one of the oldest foraminiferal types, for it occurs in the upper Silurian of Woolhope (Brady). The species is rare in the English Crag and the Pliocene of San Pedro, but the related type $L$. acuticosta Reuss is common. L. sulcata is rare in the Pleistocene of Santa Barbara.

\section{Subfamily NODOSARIIN E.}

Genus NODOSARIA.

\section{NoDosaria CaLOMORPHa Reuss.}

Plate XV, figures 3 , a, b.

Nodosaria calomorpha Reuss, 1865, Denkschr. Akad. Wiss. Wien, vol. 25, p. 129, Pl. I, figs. 15-19.

Nodosaria calomorpha Brady, 1884, Challenger Rept., vol. 9, p. 497, Pl. LXI, figs. 23-27 (figs. 23 and 25 typical).

Nodosaria calomorpha Goes, 1894, Kongl. Svenska Vetenskaps-Akad. Handl., Bd. 25, No. 9, p. 72, Pl. XIII, figs. 712, 713.

Description.- - The test of Nodosaria calomorpha appears to be limited to two or three segments, which resemble those of Nodosaria radicula (Linnæus) or Nodosaria pauperata (D'Orbigny). The primordial chamber is round and stout but shorter than the ultimate chamber. The septa are depressed and straight. When three segments are present the form is slightly dentaline, though perhaps not invariably so. Where present in association with $N$. pauperata, as at San Pedro, it might be assigned to that species as a young form, but it is too large and is evidently an adult organism.

The specimen figured by Parker and Jones ${ }^{1}$ under the name Dentalina consobrina belongs to Nodosaria calomorpha and is, in fact, typical for this species.

Distribution.-Oligocene (Septaria clays of Germany), Pliocene, and Recent. Found in Norwegian waters at depths of 260 to 350 meters. Not common in the Pliocene sands at San Pedro, only a few specimens having been found there. 


\section{Nodosaria communis (D'Orbigny).}

Plate XVI, figures 5, 8, 9.

Dentalina communis D'Orbigny, 1826, Annales des sci. nat., vol. 7, p. 254, No. 35; 1840, Mém. Soc. géol. France, vol. 4, p. 13, Pl. I, fig. 4.

Dentalina communis Jones, Parker, and Brady (1865), 1866, Foram. Crag, pt. 1: Paleont. Soc., vol. 19, pp. 58-63, Pl. I, figs. 13-18, 20; Pl. IV, fig. 10. (All have straight septa and belong to other species. The true D. communis is Jones's "Var. B," which has oblique septa and of which he gives no illustration.)

Nodosaria communis Bagg, 1905, Bull. U. S. Geol. Survey No. 268, p. 29, Pl. V, fig. 2.

Description.-Nodosaria communis is invariably characterized by obliquely set septa, and the sutures are depressed, not flush as in Nodosaria roemeri (Neugeboren), which this species closely resembles. All the figures given in the Crag monograph under this species belong to other types. The form is highly variable in number of segments, in amount of elongation proportional to these segments, and in relative stoutness of the shell. The surface is smooth and the distal extremity rounded. The writer believes that in some forms there is a. slight tendency to basal striation, but it never becomes pronounced and the forms are never trúly apiculate. Two specimens from the Pliocene of San Pedro seem to belong to this class. One measures 2 millimeters in length, the other 2.8 millimeters. The larger form is shown in the illustration (Pl. XVI, fig. 8).

Distribution.-Permian to Recent. A very common fossil in deposits later than Lower Cretaceous. Found to-day at all depths, and in all latitudes.

\section{Nodosaria consobrina (D'Orbigny).}

Plate XV', figures 5, a-d.

Dentalina consobrina D'Orbigny, 1846, Foram. foss. Vienne, p. 46, Pl. II, figs. 1-3.

Nodosaria consobrina Bagg, 1905, Bull. U. S. Geol. Survey No. 268, p. 29, Pl. V, fig. 3.

Description.-Test similar to Nodosaria consobrina var. emaciata, but often with a terminal spine. The chambers are fewer in number - and less regular. Many specimens are of large size, but most specimens are much broken, owing to the length and fragile character of the test.

Distribution.-Cretaceous to Recent. Less abundant than the varietal form in the Pliocene sands of San Pedro, and exhibits greater variations. The species is present, but not common, in the California Miocene. 
Nodosaria consobrina (D'Orbigny) var. emaciata Reuss.

Plates XV, figures 6, a, b; XVI, figure 6 .

Dentalina emaciata Reuss, 1851, Zeitschr. Deutsch. geol. Gesell., vol. 3, p. 63, Pl. III, fig. 9.

Dentalina consobrina var. emaciata Reuss, 1865, Denkschr. Akad. Wiss. Wien, vol. 25, p. 132, Pl. II, figs. 12, 13.

Nodosaria consobrina var. emaciata Brady, 1884, Challenger Rept., vol. 9, p. 502, Pl. LXII, figs. 25, 26.

Nodosaria consobrina var. emaciata Bagg, 1898, Bull. U. S. Geol. Survey No. 88, p. 38.

Nodosaria consobrina var. emaciata Bagg, 1898, Bull. Am. Paleontology, vol. 2, No. 10, p. 319.

Description.-Test very attenuate, smooth, and tapering gracefully; numerous closely set chambers expanding only slightly; only the later segments strongly constricted by deeply depressed suture lines. Septal lines straight, distinct, but less so at the posterior end. Primordial segment rounded, in some specimen larger than the succeeding chamber. Aperture radiate, situated nearer the inner margin of the ultimate segment. Test in many specimens arcuate, but may be nearly straight. This shell can be distinguished from its congener Nodosaria consobrina (D'Orbigny) only by its larger number of segments and greater length. Both forms show considerable variation in minor details. Some specimens are of great length, one broken specimen from the Pliocene of San Pedro measuring nearly 8 millimeters.

Distribution.-Cretaceous chalk beds of England, Upper Cretaceous of New Jersey, more common in Tertiary deposits, and found in both the north and south Atlantic at the present day. Not very common in the Pliocene of San Pedro.

\section{Nodosaria DeCEPTa n. $\mathrm{sp}$.}

Plate XVI, figure 1.

Description.-Test elongate, dentaline, and composed of eight or nine chambers, which, in the anterior portion of the shell, resemble those of Nodosaria pauperata (D'Orbigny), though the ultimate segment seems to have an oblique septa as in Dentalina communis D'Orbigny. Lower half of the shell costate, the number of costre being interrupted over some segments and continuous over others. It resembles Nodosaria vertebralis (Batsch) in the costæ and chamber arrangement of the posterior portion of the shell.

The form has about 12 striations, which become stronger below and fade out toward the anterior part of the shell. The ultimate segment is bulbous, is larger than that succeeding it, and is furnished with a spine. The ultimate chamber is prolonged anteriorly, and a circular aperture with radiate border lies upon the inner arcuate side. The 
septa are strongly depressed and with the exception of the ultimate chamber are transverse. The form closely resembles Nodosaria communis (D'Orbigny) in its surface ornamentation, but has fewer striæ, and the septa are not obliquely set except at the ultimate end. The form also resembles Nodosaria pauperata, but the latter has no surface costæ.

The septal lines are wide, as in Nodosaria vertebralis, but the form is dentaline. This form may be either an aberrant type or a variety of some one of the very numerous recorded forms of Nodosaria which show surface ornamentation, but it does not seem to coincide with any of the figured species of Tertiary or Recent Foraminifera, and the writer has thought it best to consider it a new species.

Only a few specimens appear in the Pliocene sands of San Pedro, and these are slightly worn. The two specimens illustrated herewith measure 4.5 millimeters in length.

\section{Nodosaria farcimen (Soldani).}

1

Plate XVII, figure 3.

Orthoceras farcimen Soldani, 1791, Testaceographia, vol. 1, pt. 2, p. 98, Pl. CV, fig. 0 . Nodosaria farcimen Bagg, 1905, Bull. U. S. Geol. Survey No. 268, p. 30, Pl. V, fig. 5.

Description.-The following description is quoted from the writer's report on the Monterey shale:

The test of Nodosaria farcimen consists of a small number of smooth segments (generally less than ten) separated by straight instead of oblique septa, as in Nodosaria communis (D'Orbigny), which the species resembles. The chambers are longer than in Nodosaria soluta Reuss, and in the typical forms constricted rather deeply, each succeeding chamber enlarging rapidly. The shell is curved and the nipple-shaped aperture is located on the inner margin of the curve in a prolongation of the ultimate segment. The length is extremely variable, being 2.82 millimeters in the Cretaceous specimens and only 1.10 millimeters in the Maryland Eocene. The California forms are smaller yet, and are so fragile that entire specimens are extremely difficult to obtain. The best form in the present collection has eight segments.

In the Pliocene of San Pedro, all the specimens are broken, and the type is not well represented, though the specimens are very large, unlike those of the California Miocene mentioned above.

Distribution.-Permian to Recent. Known at almost all depths and in all oceans. Only a few fragmentary forms were obtained from the Pliocene of San Pedro. 


\section{Nodosaria OBLIQUA (Linnæus).}

Plates XV, figures 1, a-d; XVII, figures 1, a-d.

Nautilus obliquus Linnæus, 1767, Syst. Nat., 12th ed., p. 1163, No. 281; 1788, 13th ed. (Gmelin's), p. 3372, No. 14.

Nodosaria obliqua Flint, 1899, Recent Foram.: Rept. U. S. Nat. Mus. for 1897, p. 311, pl. 57, fig. 4.

Nodosaria obliqua Goes, 1894, Kongl. Svenska Vetenskaps-Akad. Handl., Bd. 25, No. 9, p. 70, Pl. XII, figs. 691-696; not Pl. XIII, figs. 697-699.

Nodosaria obliqua Bagg, 1905, Bull. U. S. Geol. Survey No. 268, p. 31, Pl. V, fig. 7.

Description.-This species varies greatly in size, length, and arcuate character, and in the number of its striations, which are oblique and unite irregularly along their vertical extension. The segments are typically ventricose with depressed septa, but these are less differentiated toward the initial segment, which is often acuminate, though it may be bulbous and have the primordial chamber larger than the next succeeding one.

If all forms with very numerous oblique strix and the dentaline and nodosarian types are included, the synonymy is very extensive.

Distribution.-Permian to Recent. Present in the New Jersey Cretaceous (Bagg), where the forms are very much larger and better developed than in the California Miocene, where the species is rare and the specimens minute. This form was not recognized in the Pliocene of San Pedro, though many forms of Nodosaria of large size are present, but the writer has recorded the occurrence of a fragment of the form from the Pleistocene of Santa Barbara. ${ }^{1}$ Though $N$. obliqua is widely distributed over existing oceans and occurs at all depths, it is best known as a Tertiary fossil.

\section{Nodosaria PaUperata (D'Orbigny).}

Plate XVI, figures 2, a-f.

Dentalina pauperata D'Orbigny, 1846, Foram. foss. Vienne, p. 46, Pl. I, figs. 57, 58. Nodosaria pauperata Brady, 1884, Challenger Rept., vol. 9, p. 500, woodcuts, fig. 14. Dentalina pauperata Jones, 1896, Foram. Crag, pt. 3: Paleont. Soc., vol. 50, p. 224, Pl. I, figs. 13-18, 20.

Nodosaria pauperata Goes, 1894, Kongl. Svenska Vetenskaps-Akad. Handl., Bd. 25, No. 9 , p. $68, \mathrm{Pl}$. XII, figs. $672-688$ (figs. 674,675 , and 686 probably $N$. consobrina var. emaciata Reuss).

Description.-Test smooth, straight, or somewhat arcuate, tapering slightly; typically enlarged at aboral end. Primordial segment in some specimens apiculate; ultimate chamber prolonged, larger than preceding, and provided with a constricted tubelike neck at the anterior end. Aperture round, radiate, and usually unsymmetrical in arcuate forms. The test is commonly of great size, specimens from 
the Pliocene of San Pedro measuring more than 7 millimeters in length. Many of the specimens with few chambers are perfectly straight, but when the number of segments is 8 or more the forms are dentaline. The specimen resembling Bigenerina figured on Plate $\mathrm{XV}$ (fig. 4) probably belongs here. It is an aberrant dimorphous form, not well placed under any species.'

Distribution.-Lower Jurassic to Recent. Rather common in the Tertiary. The writer found this species in the Upper Cretaceous of New Jersey and in the California Miocene. The species is fairly abundant, perhaps the most common Nodosaria, in the Pliocene sands of San Pedro.

\section{Nodosaria sagrinensis n. sp.}

Plate XVI, figure 4.

Description.-Test straight; composed of seven, possibly eight, globose segments, sharply expanding, and with nodes becoming longer toward the ultimate chamber. Septal region broad in later segments, and narrows with suggestions of faint striæ toward the distal extremity. The chambers tend to become angular at their margins, and have the lower margin shorter, so as to give the shell an inset effect, even though the segments are apart. The aperture is like that of the typical Sagrina and the flaring phialine lip is pronounced. There are no biserial segments in the initial portion, however, as in typical Sagrina forms; the shell is nodosarian throughout. The figure published in the Challenger report ${ }^{1}$ under the term Sagrina virgula Brady is of all published forms known to the writer the most like this species. The shell shows a slight roughness, almost hispid, as in Nodosaria hispida, but the striæ suggestions seem to lie on the nodes, 'not on the surface of segments. The writer has only one perfect specimen from the Pliocene at San Pedro, but it seems to be a new form. Its striking resemblance to Sagrina has suggested the name given it.

The two genera Sagrina and Nodosaria are very different morphologically, for although many species of Sagrina become nodosarian in their late segmentation they still show the dimorphous character which is so important in their generic development. Moreover, the flaring phialine aperture is very rare in Nodosaria. The length of the specimen obtained by the writer is 0.64 millimeter. 


\section{Nodosaria SEMINUdA Reuss.}

Plate XVI, figures 3, a-c.

Dentalina seminuda Reuss, 1850, Denkschr. Akad. Wiss. Wien, vol. 1, p. 367, Pl. XLVI, fig. 9.

Nodosaria seminuda Reuss, 1870, Sitzungsber. Akad. Wiss. Wien, vol. 62, pt. 1, p. 476; fig. in Von Schlicht, Foram. Septar. Pietzpuhl, 1870, Pl. VIII, fig. 20.

Nodosaria seminuda Goes, 1894, Kongl. Svenska Vetenskaps-Akad. Handl., Bd. 25, No. 9, 71, Pl. XIII, fig. 700.

Description.-The test of Nodosaria seminuda is large, those obtained by Goes from depths of 530 meters in the Caribbean Sea measuring 18 to 22 millimeters in length. The lower portion of the test carries a few surface striæ, but the upper portion is smooth and shining. The chambers are rather closely set and the form stout. The septa are not strongly depressed, nor are the segments constricted, though they tend to become so toward the ultimate chambers. The Pliocene sands of San Pedro contain a comparatively large number of this species. Many are perfect, and the longer forms are 6 millimeters in length. They are not as straight as the type illustrated by Goes. The primordial chamber is less bulbous than the type, but it carries the spinous prolongation characteristic of the species.

Distribution.-This form is common in the Pliocene sands of San Pedro and in the Caribbean Sea.

\section{Nodosaria soluta (Reuiss).}

Plates XV, figures 2, a, b; XVI, figure 7 .

Dentalina soluta Reuss, 1850, Haidinger's Naturw. Abhandl., vol. 4, p. 25, Pl. II, fig. 10.

Nodosaria soluta Goes, 1894, Kongl. Svenska Vetenskaps-Akad. Handl., Bd. 25, No. 9, p. 70, Pl. XII, fig. 690 .

Nodosaria soluta Bagg, 1905, Bull. U. S. Geol. Survey No. 268, p. 34, PI. V, fig. 2.

Description.-Shell smooth, straight, or arcuate; segments inflated; septa depressed and transverse; some specimens mucronate; few chambers. The deep constrictions between the chambers make these shells fragile, and they are seldom preserved entire.

Distribution.-Cretaceous to Recent. Inhabits the North Atlantic to-day at depths ranging from 360 to 1,360 fathoms (Brady). The species is very abundant in the California Miocene but rare in the Pliocene sands of San Pedro. 


\section{Nodosaria VERTEBRaLIS (Batsch).}

Plate XVII, figure 2.

Nautilus (Orthoceras) vertebralis Batsch, 1791, Conchyl. des Seesandes, p. 3, No. 6, Pl. II, fig. 6.

Nodosaria vertebralis Brady, 1884, Challenger Rept., vol. 9, p. 514, Pl. LXIII, fig. 35; Pl. LXIV, figs. 11-14.

Nodosaria vertebralis Flịnt, 1899, Recent Foram.: Rept. U. S. Nat. Mus. for 1897, p. 312 , pl. 57 , fig. 5 .

Description.-The test of Nodosaria vertebralis is long and tapering, with numerous segments, closely set and not separated by constricted septa. The septa are fairly wide and appear as dark bands, transverse but not oblique as in Nodosaria communis D'Orbigny. The lack of constriction and the smaller number of raised striæ separate this form from Nodosaria obliqua. There is a slight tendency for these ribs to become twisted, but beyond the first few segments they run parallel to the length of the shell. The primordial chamber is enlarged, and is provided with a spine.

Distribution.-Cretaceous to Recent. This species is present in the New Jersey Cretaceous, but is better known in late Tertiary deposits. The few fragmentary specimens from the Pliocene of San Pedro are not very typical and appear rather waterworn. It is found in shoal waters of the north and south Atlantic. The writer obtained it in dredgings at depths of about 100 fathoms off the Hawaiian Islands, in the Pliocene of San Pedro, and in the Pleistocene of Santa Barbara near the hill crest.

Genus FRONDICULARIA.

\section{Frondicularia Inatudalis Costa.}

Plate XVIII, figures 1, a-e, 2, a-e.

Frondicularia inæqualis Costa, 1855, Mem. Acad. sci. Napoli, vol. 2, p. 372, Pl. III, fig. 3.

Frondicularia inæqualis Brady, 1884, Challenger Rept., vol. 9, p. 521, Pl. LXVI, figs. 8-12.

Flabellina inæqualis Brady, 1879, Quart. Jour. Micr. Sci., vol. 19, new ser., p. 57, Pl. VIII, figs. 8-10.

Description.-Test lanceolate and complanate, consisting of a large number of biserial segments which are unequally arranged, not symmetrical as in Frondicularia alata D'Orbigny. These segments increase notably in size toward the anterior end. The initial chamber is minute, slightly bulbous, and unsymmetrically placed. The margin is entire and rounded and tapers gradually from the median portion to the oral extremity.

The San Pedro specimens show a peculiar furrow along the central axis, due to a swelling of the segments toward their periphery. The 
surface is smooth, and the shell substance glistening and nearly iransparent. The length of the larger specimens from San Pedro is 2.5 millimeters. Recent specimens are fragile, and according to Brady seldom found entire. The Pliocene forms from San Pedro are comparatively well preserved, and many show the delicate spine on the initial chamber. They are strongly built and are apparently of greater size than the figured types of the species.

Distribution.-Miocene to Recent. Abundant in the Pliocene at San Pedro. Frondicularia is rare in existing oceans, and this species is recorded by the Challenger expedition at only six stations, most of those in shallow waters. The genus seems to be most characteristic of the earlier Tertiary and Cretaceous formations, and the surface ornamentation is more pronounced in these older types than in existing species of Frondicularia.

\section{Frondicularia latevigata Karrer.}

Plate XVIII, figure 3.

Frondicularia lævigata Karrer, 1868, Sitzungsber. Akad. Wiss. Wien, p. 167, Pl. IV, fig. 3.

Description.-Test very minute, strongly compressed, winglike but narrow, lanceolate, with ultimate chamber tapering to radiate aperture placed centrally in final segment. Initial chamber slightly enlarged; lower portion of shell ornamented with a few (4 to 6) longitudinal striations, upper portion smooth and glistening. According to Karrer, in some specimens the entire shell is without surface costæ, but in the forms collected by the writer the margins are angular and the striæ are pronounced. None of the specimens are perfect, however, and there is some doubt whether the form should be placed under this species or under Frondicularia mucronata, found in the Miocene of Austria, a form which has the angularity of the margin, is extremely narrow, and has only two to four costæ. The writer's fragments of this minute species seem to belong to $F$. lævigata, and if so they represent the lower portion of the test.

The fragments obtained from the Pliocene of San Pedro measure 0.5 to 0.8 millimeter in length.

Distribution.-This species is found only in Miocene and Pliocene deposits. Two specimens were obtained from San Pedro. 
Genus MARGINULINA.

\section{Marginulina costata (Batsch).}

Plate XVIII, figure 4.

Nautilus (Orthoceras) costatus Batsch, 1791, Conchyl. der Seesandes, p. 2, Pl. I, fig. 1.

Marginulina costata Jones, Parker, and Brady, 1866, Foram. Crag, pt. 1: Paleont. Soc., vol. 19, Pl. I, fig. 21 (also describęd by Jones in Paleont. Soc., vol. 50, 1896, pp. 235-238.)

Description.-The following description is that given by Jones:

This nodosarine is essentially a Nodosaria having an eccentric growth, which gives either an oblique or partially spiral style of growth to the early chambers, and a marginal aperture (with or without a short neck) to the older and the last segments. It varies in cross section from subcylindrical to oval and compressed. The chambers are moderately compact, more or less septate, and therefore varying in relative fullness; and are marked with longitudinal riblets, as in Nodosaria raphanus, of which, indeed, this is essentially only a marginuline modification.

The complete synonymy of this species is very extensive and would include many descriptions of Marginulina raphanus Linnæus.

The shell is composed of relatively few segments, which are short and closely set. The surface ornamentation of these toward the initial end consists of relatively few, rather strong, slightly curved costæ, which are in some specimens interrupted, and which in almost none invest the ultimate chamber. The initial segment is in many specimens apiculate. The length of the San Pedro specimens is 1.5 millimeters.

The position of the eccentric aperture and the compressed chamber distinguish this form from Nodosaria obliqua, and the compressed marginuline character distinguishes it from Nodosaria raphanus.

Distribution.-Lower Jurassic to Recent. Known in north and south Atlantic and elsewhere, but apparently absent from the Pacific except near New Zealand. A few specimens were obtained from the Pliocene at San Pedro.

\section{Marginulina glabra D'Orbigny.}

Plate XXI, figures 17, a, b.

Marginulina glabra D’Orbigny, 1826, Annales des sci. nat., vol. 7, p. 259, No. 6, modèle 55 .

Marginulina inæqualis Reuss, 1860, Sitzungsber. Akad. Wiss. Wien, vol. 40, p. 207, Pl. VII, fig. 3.

Marginulina inæqualis Reuss, 1862, Sitzungsber. Akad. Wiss. Wien, vol. 46, p. 59, Pl. V, fig. 13; Pl. VI, fig. 8.

Marginulina glabra Brady, 1884, Challenger Rept., vol. 9, p. 527, Pl. LXV, figs. 5, 6.

Description.-Test short, stout, slightly curved, and partly spiral; chambers smooth, rapidly enlarging, separated by depressed septa; anterior bulbous, carrying radiate aperture on inner margin. 
Distribution.-Lower Jurassic (Lias) to Recent. Recorded by many investigators as a Cretaceous type. Rare in the Pliocene of San Pedro, and both rare and small in the English Crag. The species has a wide geographic distribution to-day, but is apparently not found in the far North. Its bathymetric range is from a few fathoms tố nearly 3,000 fathoms.

\section{Genus VAGINULINA.}

\section{VAGINULINA BADENENSIS D'Orbigny.}

Plate XVIII, figures $5, \mathrm{a}, \mathrm{b}$.

Vaginulina bädenensis D'Orbigny, 1846, Foram. foss. Vienne, p. 65, Pl. III, figs. 6-8. Vaginulina badenensis Goes, 1894, Kongl. Svenska Vetenskaps-Akad. Handl., Bd. 25, No. 9, p. 66, Pl. XII, figs. 662, 663.

Description.-Test very elongate, strongly compressed; consists of 10 to 18 segments in D'Orbigny's specimens from the Miocene of the Vienna Basin and of 10 to 17 in the San Pedro specimens. Ultimate chamber prolonged and furnished with radiate aperture upon the inner arcuate margin. Primordial chamber furnished with a long, sharp spine, probably two or three times the length of the initial segment in perfect specimens.

The septa are similar to those of Vaginulina legumen, which the form very closely resembles, but they are more oblique and show a sharp tendency to arch at an angle near the side curving inward. This feature is indicated in many published figures of Vaginulina legumen, but the angulation is not so pronounced. The -septa are distinct but not so strongly depressed, and the specimens taper gradually from the ultimate to the aboral end. The spinous character, the greater arching of the septa, and the dentaline character of the shell readily distinguish this species from $V$. legumen (Linnæus). The San Pedro specimens are very large, one measuring nearly 8 millimeters in length. Goes states that the specimens dredged at a depth of 1,740 meters in the north Atlantic are 4 to 7 millimeters in length, but shore forms from the Norwegian seas measured only 2 or 3 millimeters.

Distribution.-Miocene to Recent. Not uncommon in the Pliocene of San Pedro.

\section{VAGINULINA LEgUMEN (Linnæus). .}

Plate XVIII, figures 6,7 .

Nautilus legumen Linnæus, 1758, Syst. Nat., 10th ed., p. 711; 1767, idem, 12th ed., No. 248 , p. 1164, No. 288.

Vaginulina legumen Bagg, 1898, Bull. U. S. Geol. Survey No. 88, p. 53, Pl. IV, fig. 4.

Description.-Test strongly compressed and podlike, but straight on the margin which carries the aperture. The septa are oblique and somewhat depressed; the surface is smooth. The ultimate $45625^{\circ}-$ Bull. $513-12-5$ 
chamber is prolonged on the inner margin into a nipple-shaped fissured aperture; the initial segment may be with or without spine. The specimens from San Pedro are generally provided with a short spine and are large, many of them measuring 5 millimeters in length.

This is one of the oldest forms of the genus Vaginulina. The Mesozoic species of Vaginulina are commonly ornamented upon the surface with costæ, but Tertiary and Recent specimens are generally smooth.

Distribution.-Triassic to Recent. The species is very abundant in the Pliocene of San Pedro. It is commonly found in shallow waters, but has been obtained in soundings of more than 2,000 fathoms.

\section{Vaginulina Legumen (Linnæus) var. arquata Brady。}

Plate XVIII, figures 8 , a-c.

Vaginulina legumen var. arquata Brady, 1884, Challenger 'Rept., vol. 9, p. 531., Pl. CXIV, fig. 13.

Description.-This large-shelled variety of Vaginulina legumen is considerably arcuate. Typical forms of $V$. legumen show the apertural margin perfectly vertical. This variety is strongly bent and tapers at the extremities, which may be somewhat apiculate at the distal end. Brady gave the name to a rather widespread type of large dimensions (one-half inch in length) which occurs in the north Atlantic. A number of specimens of Vaginulina from San Pedro, equally large, are of this variety.

Distribution.-Pliocene (San Pedro) and Recent.

\section{Vaginulina linearis (Montagu).}

Plate XVIII, figures $9, a, b$.

Nautilus linearis Montagu, 1808, Test. Brit., Suppl., p. 87, Pl. XXX, fig. 9.

Vaginulina linearis Goes, 1894, Kongl. Svenska Vetenskaps-Akad. Handl., Bd. 25, No. 9, p. 66, Pl. XII, fig. 664 .

Description.-The test of Vaginulina linearis resembles the dentaline variety of nodosarian types but is more compressed and usually more arcuate. The most important and characteristic feature of the test is its surface costæ, which are limited to about the lower half of the shell, the upper or oral end being smooth. The costæ vary considerably in number, though they are not so numerous as in Nodosaria obliqua (Linnæus) or Vaginulina obliquistriata Jones. The aperture is variable but usually eccentric. The initial chamber is apiculate. Some of the specimens obtained at San Pedro are 3.5 millimeters in length.

Distribution.-Eocene (London clay) to Recent. Rather common in shallow temperate and boreal waters of existing oceans. The species is not uncommon in the Pliocene of San Pedro. 


\section{VaginUlina obliquistriata Jones.}

Plate XVIII, figures 10, 11.

Vaginulina obliquistriata Jones, 1896, Foram. Crag, pt. 3: Paleont. Soc., vol. 50, p. 231, Pl. V, figs. 9-11.

Description.-Test short and stoutly built, consisting of a few chambers closely set and demarked by slightly oblique septa. Surface ornamented by a number of obliquely set pronounced striations, which extend nearly the whole length of the shell and which are somewhat more prominent toward the distal end. Shell either straight or slightly dentaline; aperture on inner side of curve, as in typical Vaginulina forms. Test is only slightly compressed, less so than Vaginulina striata D'Orbigny (Soldani), which, according to Jones, is the type of variety $\theta$ on page 66 of the monograph on the Foraminifera of the Crag, Part I. It is considered by Jones a distinct species.

A similar form, with interrupted costæ, is given by Reuss ${ }^{1}$ under the name Dentalina divergens. Vaginulina linearis is similar to this type, but its surface striæ extend only over the earlier portion of the shell, never to the ultimate segment.

Distribution.-Pliocene of England and of San Pedro, Cal. Rare at San Pedro.

\section{Genus CRISTELLARIA.}

Cristellaria crepidula (Fichtel and Moll).

Plate XIX, figure 3.

Nautilus crepidula Fichtel and Moll, 1803, Test. Micr., p. 107, Pl. XIX, figs. g-i.

Cristellaria cymboides D'Orbigny, 1846, Foram. foss. Vienne, p. 85, Pl. III, figs. 30, 31. Cristellaria crepidula Goes, 1894, Kongl. Svenska Vetenskaps-Akad. Handl., Bd. 25,

No. 9, p. 62, Pl. XI, figs. $596,613$.

Description.-The test of Cristellaria crepidula is strongly compressed, erect, and elongate. The chambers first form an involute spiral, but soon diverge with almost straight septal lines to the periphery, giving a triangular appearance to each segment. These septal lines are depressed and show as bright bands in pellucid types. The septal face is almost vertical and is narrow, carrying upon its inner surface the circular radiate aperture. The outer periphery is broadly curved but is noncarinate, even in very thin and delicate specimens, and the surface is perfectly smooth. In outline, the form is subject to considerable variation within certain limits, and the synonymy is long, owing to this variation.

Distribution.-Lower Jurassic (Lias) to Recent. Not common in the Cretaceous but better known in Tertiary 'and Recent deposits. 
Found in all seas and at all depths, but nowhere very abundant. A single specimen was obtained from the Pliocene at San Pedro, but several of Cristellaria reniformis D'Orbigny, which this form somewhat resembles.

\section{Cristellaria gibBa D'Orbigny.}

Plate XIX, figures 4, a-c.

Cristellaria gibba D'Orbigny, 1839, Foram. Cuba, p. 63, Pl. VII, figs. 20, 21.

Cristellaria pulchella Reuss, 1862, Sitzungsber. Akad. Wiss. Wien, vol. 46, p. 71, Pl. VIII, fig. 1.

Cristellaria gibba Goes, 1894, Kongl. Svenska Vetenskaps-Akad. Handl., Bd. 25, No. 9, p. 61, Pl. X, figs. 587-592.

Description.-Test occupies an intermediate position between the thin complanate Cristellaria crepidula and the lenticular C. rotulata (Lamarck). It is more elongate than the latter, and its, narrow septal face distinguishes it from Cristellaria acutauricularis (Fichtel and Moll), which it closely resembles.

Distribution.-Lower Cretaceous to Recent. Found living to-day in the north Atlantic and south Pacific at depths less than 500 fathoms. Rare in the Pliocene of San Pedro.

\section{Cristellaria josephina D'Orbigny.}

Plate XIX, figures $1, a, \dot{b}$.

Cristellaria josephina D'Orbigny, 1846, Foram. foss. Vienne, p. 88, Pl. III, figs. 37, 38.

Description.-This shell seems to be very rare. The name was used by D'Orbigny to include forms oval, strongly compressed, smooth, and shining, with 12 narrow chambers separated by depressed septa which extend almost straight to the periphery. The shell uncoils a little toward the distal end, so that the ultimate segments do not reach the umbilicus. One perfect specimen from the Pliocene of San Pedro has 10 segments in the final convolution and corresponds well with this species. It may possibly be regarded as a variety of Cristellaria crepidula (Fichtel and Moll), but in some features it is specifically distinct.

Distribution.-Apparently limited to the Miocene (Vienna Basin) and Pliocene (San Pedro). Very rare at San Pedro.

\section{Cristellaria Reniformis D'Orbigny.}

Plate XIX, figures 2, a, b.

Cristellaria reniformis D'Orbigny, 1846, Foram. foss. Vienne, p. 88, Pl. III, figs. 39, 40. Cristellaria reniformis Jones, 1895, Foram. Crag, pt. 2: Paleont. Soc., vol. 49, p. 248, Pl. VII, figs. $18 \mathrm{a}, \mathrm{b}$.

Description.-Test strongly compressed; with elongate triangular segments-9 to 12 in the San Pedro specimens. Septa distinct but not much depressed. Periphery keeled around entire outer margin 
except the septal face border on anterior edge. Shell rounded and involute below, extended above; chambers assume an acuminate terminus, which is a rather variable character. The species is closely related to Cristellaria compressa, but the latter is more arcuate, somewhat narrower, and perhaps thicker in the umbilical region.

Distribution.-Eocene (London clay), Miocene (Vienna Basin), Pliocene (English Crag), and Recent. Found in the north Atlantic at depths of 300 to 1,000 fathoms, the south Atlantic at 1,900 fathoms, the north Pacific at 2,050 fathoms, and the south Pacific at 150 to 1,100 fathoms. Cristellaria is not at all common in the Pacific coast Tertiary and later deposits. None were discovered by the writer in the Pleistocene of Santa Barbara, and only a few specimens in the Pliocene of San Pedro.

\section{Cristellaria rotulata (Lamarck).}

Plate XIX, figures 5, a, b.

Lenticulites rotulata Lamarck, 1804, $\Lambda$ nnales du Muséum, vol. 5, No. 3, p. 188; Tab. encycl. et méthod., Pl. CCCCLXVI, fig. 5.

Cristellaria roiulata Parker and Jones, 1865, Philos. Trans., vol. 155, p. 345, P1. XIJI, fig. 19 (Arctic).

Description.-Test involute, biconvex, smooth; peripheral margin sharp but noncarinate; chambers numerous, usually about 8 in final convolution, but the San Pedro Pliocene forms show 12 septa moderately curved and visible externally as fine lines (in some specimens, particulariy from the north Atlantic, the septa appear slightly raised); aperture elliptical; radiate shell of variable size.

The forms of Cristellaria that occur in the Pliocene sands of San Pedro show a tendency to become carinate. They are large (1.5 millimeters in diameter), and have a thick shell substance.

The forms of Cristellaria rotulata which occur to-day in the north Atlantic and Arctic oceans are equal in size to those of the Cretaceous chalk and marl beds and the New Jersey greensands. According to Parker and Jones, the largest. specimens of thic species come from the sub-Apennine Tertiary deposits, the Vienna Basin, and the Tertiary beds of Jamaica and Santo Domingo.

Distribution.-Triassic to Recent. Smaller in size but more numerous in the earlier deposits than in the Tertiary. Abundant in existing oceans, and occurs at all depths, from a few fathoms to 2,000 or more. The species is rare in the California Miocene, ${ }^{1}$ and only a few specimens were noted in the Pliocene sands of San Pedro.

1 Bagg, TR. M., jr., Mioceno Foraminifera from California: Bull. U. S. Geol. Survey No. 268, 1:05, p. 37, Pl. V, fig. 7. 


\section{Subfamily POLYMORPHININ $A$.}

\section{Genus DIMORPHINA.}

\section{Dimorphina tuberosa D'Orbigny.}

Plate XIX, figures 6, 7 .

Dimorphina tuberosa D’Orbigny, 1826, Annales des sci. nat., vol. 7, p. 264, No. 1, modèle 60 .

Dimorphina tuberosa Jones, Parker, and Brady, 1866, Foram. Crag, pt. 1: Paleont. Soc., vol. 19 (1865), No. 57 (part), Pl. I, fig. 61 (not fig. 66).

Dimorphina tuberosa Jones, 1896, Foram. Crag, pt. 3: Paleont. Soc., vol. 50, pp. 274, 275, Pl. VII, fig. 21.

Description.-Jones describes this form as follows:

Shell elongate, subcylindrical,-straight or nearly so. Anterior portion acuminate; posterior obtuse and rounded. Early (alternating) chambers varying greatly in their proportion to the whole shell. Later (uniserial) chambers two to six in number, more or less inflated.

Distribution.-Tertiary to Recent. This form is considered a very rare fossil. Like Polymorphina nodosaria Reuss, its near relative, it is present at San Pedro, but only four or five specimens were found. It occurs in the English Crag in the St. Erth Pliocene, and is reported as living in the Mediterranean.

\section{Genus POLTMORPHINA.}

\section{Polymorphina communis D'Orbigny.}

\section{Plate XXI, figures 7, a, b, 13-15.}

Polymorphina communis D'Orbigny, 1826, Annales des sci. nat., vol. 7, p. 266, No. 15, Pl. XII, figs. 1-4; modèle 62 .

Polymorphina communis Brady, 1884, Challenger Rept., vol. 9, pp. 568, 569, Pl. LXXII, fig. 19 (typical).

Polymorphina communis Brady, Parker, and Jones, 1870, Trans. Linn. Soc. London, vol. 27, p. 224, Pl. XXXIX, fig. 10. (Copied from D'Orbigny's original figure in Tableau méthodique.)

Description.-The test of Polymorphina communis is closely related in its segmentation to Polymorphina problema, but the former is acuminate at its oral extremity. It also has fewer chambers, and these are less depressed. Many figured specimens do not exhibit this feature, and the figures of Polymorphina communis given in the Crag monograph show just the reverse. Were it not that the two species have become firmly. established, one of the terms might be allowed to lapse, but D'Orbigny's original figures make it possible to keep the two species distinct. The synonymy of this species is very large and is fully stated in Part III of the monograph on the Crag. ${ }^{1}$

Distribution.-Lower Jurassic (Lias) to Recent; more common than its congener. Very rare in the Pliocene of San Pedro. Occurs also 
in the Pleistocene of Santa Barbara on the hill, but was not observed in the lower beds along the beach bluffs.

\section{Polymorphina complanata D'Orbigny.}

Plate XX, figures 13, 14.

Polymorphina complanata D'Orbigny, 1846, Foram. foss. Vienne, p. 234, Pl. XIII, figs. 25-30.

Polymorphina complanata Brady, Parker, and Jones (1869), 1870, Trans. Linn. Soc. London, pp. 230, 231, Pl. XL, figs. 14, a, b, and woodcuts, p. 230 (f, g, h, i, and j). Polymorphina complanata Jones, Parker, and Brady (1865), 1866, Foram. Crag, pt. 1: Paleont. Soc., vol. 19, p. 270; Paleont. Soc., vol. 50, 1896, Pl. I, figs. 52, 53, and 60 .

Description.-Polymorphina complanata, although extremely variable in its configuration, is nevertheless readily recognized. The test is much compressed, is more or less ovate, and has symmetrical chambering in biserial manner. The septa are not so much depressed as in Polymorphina compressa, and the margin is straight. 'This species seems to present greater variations in its outline, according to the horizon at which it appears, than any other foraminifer known. The Pliocene specimens, for example, are always narrow elongate, not widely flattened, like those in the Miocene. The woodcuts shown in the monograph on the genus Polymorphina ${ }^{1}$ are most typical for the shapes of this species at the several horizons at which it occurs fossil. In the Pliocene at Timms Point, San Pedro, the species is the most numerous Polymorphina and the specimens are large (3.5 millimeters in length) and well developed. None are of the broadly ovate Miocene type. They resemble rather those from the English Crag, where similar specimens occur at every horizon.

Distribution.-Cretaceous to Pleistocene. As a rule it is less common than its congener Polymorphina compressa, and it seems to be absent from existing oceans. Six specimens of this species were discovered by the writer in the Pleistocene at Santa Barbara, near the crest of the shore hills.

\section{Polymorphina compressa D'Orbigny.}

Plates XX, figures 7-9, 19-21; XXI, figures 9-11, b.

Polymorphina compressa D'Orbigny, 1846, Foram. foss. Vienne, p. 233, PI. XII, figs. 32-34.

Polymorphina compressa Brady, Parker, and Jones, 1870 (1869), Trans. Linn. Soc. London, vol. 27, p. 227, PI. XL, fig. $12 \mathrm{a}-\mathrm{f}$ (a, b, and c show the Crag types; the specimens from San Pedro resemble figure c).

Polymorphina compressa Jones, 1896, Foram. Crag, pt. 3: Palèont. Soc., vol. 50, pp. 259-261, Pl. I, figs. 54, 65, 77-80; (distorted) Pl. V, figs. 26, 28.

Description.-Jones gives the following description of this form:

Shell oblong, inequilateral, compressed, more or less fusiform. Chambers numerous, arranged in two unequal series, somewhat inflated. Septal lines depressed. Surface 
smooth. Aperture' variable, usually simple, circular, and coronate, sometimes labyrinthic or porous.

Polymorphina compressa and Polymorphina complanata are more closely related than most of the published figures would lead one to suspect. The latter has a larger number of more symmetrical segments, and the outline is more regular and less lobate. The amount of compression and the position and size of the chambers in Polymorphina compressa are variable. The species lacks the symmetrical chamber arrangement, the segments are more èlevated between the depressed septa, and segmentation is less marked than in typical forms of its allied species. Many of the San Pedro specimens, which are 1 to 3 millimeters in length, approach the narrow, thick forms of the English Crag Pliocene Polymorphina complanata type, but the lobate border, the asymmetrical chambering, and the depressed sutures characterize the more typical specimens.

Distribution.-Lower Jurassic (Lias) to Recent. Most abundant in the late Tertiary. Very abundant in the deposits at Timms Point, San Pedro, but less numerous than Polymorphina complanata. Rare in the Pleistocene at Santa Barbara, only one specimen being detected in the lower beds along the beach bluffs.

Though of wide geographic and bathymetric distribution in present oceans, the more typical specimens come from shoal waters in temperate zones. Small specimens are fairly common off the Norwegian Coast, according to Parker and Jones.

\section{Polymorphina cylindroides Roemer.}

Plate XXI, figures $6, a, b$ :

Polymorphina cylindroides Roemer, 1838, Neues Jahrb., 1838, p. 385, Pl. III, fig. 26. Polymorphina compressa (in part) Parker and Jones, 1865 (1864), Philos. Trans., vol. 155, p. 361, Pl. XIII, figs. 48, a, b (not 47-51, as stated in text).

Pólymorphina cylindroides Jones, 1896, Foram. Crag, pt. 3: Paleont. Soc., vol. 50, pp. 263, 264, Pl. VI, figs. 15, a, b.

Polymorphina cylindroides Brady, Parker, and Jones, 1869, Trans. Linn. Soc. London, p. 221, Pl. XXXIX, fig. 6.

Description.-Brady, Parker, and Jones describe this form as follows:

Shell elongate, fusiform, more or less compressed. Anterior extremity acuminate, posterior acuminate or slightly rounded. Chambers elongate, arranged in two parallel series. Margins entire, scarcely depressed at the sutures. Aperture large, radiate. Surface smooth. Length $\frac{1}{30}$ to $\frac{1}{15}$ inch.

Probably the most typical figure of this species of Polymorphina is given in the monograph on. the Crag. Foraminifera. The specimen figured by Reuss ${ }^{1}$ under the same name lacks the biserial segmentation which should be present in this type. The subcylindrical, 
greatly elongate chambers and the almost entire margin are characteristic features of this species. One of the San Pedro specimens measures 3.5 millimeters, a size very large for the species.

Distribution.-Tertiary and Recent. Not common in existing oceans. It has been recorded from the Oligocene of Pietzpuhl, and typical specimens were found by Von Munster in the younger Tertiary deposits of North Germany. Only a few specimens of this form are present in the Pliocene sands of San Pedro.

\section{Polymorphina lactea (Walker and Jacob).}

Plate XXI, figures $12,16, \mathrm{a}, \mathrm{b}$.

Serpula lactea Walker and Jacob (fide Kanmacher), 1798, Adam's Essays, 2d ed., p. 634, Pl. XIV, fig. 4.

Polymorphina lactea Williamson, 1858, Recent Foram. Great Britain, p. 70, Pl. VI, figs. 145-152 (elongate variety), 149, 149 a.

Polymorphina lactea Brady, 1884, Challenger Rept., vol. 9, p. 559, Pl. LXXI, figs. $11,14$.

Polymorphina lactea and var. elongata Burrows, Sherborn, and Bailey, 1.890, Jour. Roy. Micr. Soc., p. 561, Pl. XI, figs. 9, 10.

Description.-Test typically ovate, smooth, bulbous, and slightly unsymmetrical. Anterior end acuminate, posterior rather obtuse and rounded. Chambers, few-usually only three to five visible externally-oblong, oblique, and very slightly inflated. The septal depressions are faïnt, not as deep as in Polymorphina communis D'Orbigny, and in transverse section the form is nearly circular.

Distribution.-Cretaceous to Recent. One variety, of elongate type, was obtained by the writer near the hill crest at Santa Barbara, in the Pleistocene. The species was not recognized in the Pliocene beds at San Pedro.

\section{Polymorphina nodosaria Reuss.}

Plate XXI, figures 1-3.

Polymorphina nodosaria Reuss, 1863 (1.864), Sitzungsber. Akad. Wiss. Wien, vol. 48, pt. 1, p. 58, Pl. VII, fig. 85.

Dimorphina nodosaria Jones, Parker, and Brady, 1.866, Foram. Crag, part 1: Paleont. Soc., vol. 19, pp. 262, 263, Pl. I, figs. 55-58 (not 61, which is Dimorphina tuberosa). Polymorphina nodosaria Brady, Parker, and Jones, 1870, Trans. Linn. Soc. London, vol. 27, p. 233, Pl. XI, fig. 18, a, b.

Description.-Brady, Parker, and Jones give the following description:

Shell elongate, cylindrical, somewhat tapering, irregular, composed of from four to eight chambers. Chambers oblique, inflated, alternating. Sutures constricted. Orifice central, radiate. Surface smooth. Length $\frac{1}{30}$ to $\frac{1}{15}$ inch. It may be questioned whether the uniserial Polymorphinæ typified by $P$. nodosaria belong more properly to the principal division of the group or to the subgenus Dimorphina. 
On the whole it seems most convenient to confine the term Dimorphina to those varioties which begin growth on a biserial or triserial plan and, after a certain number of segments have been formed, lapse into a single rank. * * * In the present species the mode of growth is uniserial from the commencement, or very nearly so, and its chief departure from the characters of the simpler type it otherwise resembles is in the alternating obliquity of the septal lines. * * * Thus while the genus Nodosaria has horizontal sutures connecting the chambers, and Dentalina has oblique septa, all slanting in one direction, Polymorphina nodosaria has oblique septa the direction of which is reversed with each succeeding segment. *** The general outline of the shell is somewhat irregular, from the convexity of its segments, but its central axis is straight.

The above description and discussion of this interesting and very rare type of Polymorphina is quoted at length because some confusion has long existed with regard to the use of the term Dimorphina, especially as forms described under the names Dimorphina nodosaria and Dimorphina tuberosa are separated with more or less difficulty. If the species figured under the name Dimorphina nodosaria in 1846 by D'Orbigny $^{1}$ is to be regarded as synonymous with Dimorphina tuberosa D'Orbigny, ${ }^{2}$ then Dimorphina nodosaria must be allowed to lapse. These two species are regarded as equivalent by Parker, Brady, and Jones in their monograph on the genus Polymorphina, ${ }^{3}$ in which they place Dimorphina nodosaria D'Orbigny under Dimorphina tuberosa D'Orbigny as a synonym; yet they treat as a separate species Polymorphina nodosaria Reuss, ${ }^{4}$ which differs only slightly from the original type figured as Dimorphina nodosaria by D'Orbigny. ${ }^{1}$ In D'Orbigny's figure, however, the segments in the anterior portion of the test are set in nodosarian manner with straight septa, not obliquely as in D. tuberosa. ${ }^{5}$

Polymorphina soldanii D'Orbigny is rather closely related to the above-mentioned species, but approaches Dvigerina in its segmentation. In view of the connection of these various forms with one another and with the three genera Polymorphina, Nodosaria, and Uvigerina, it seems to be most advantageous to limit Polymorphina soldanii D'Orbigny to short, many-chambered, subcylindrical tests, with smooth surface and extended margins, and with septa deeply inset and resembling those of Uvigerina. Such types go back to the chalk of Mecklenburg and also occur in the Miocene of the Vienna Basin. The species is present to-day in the shore sands of the Adriatic. The distinction between Polymorphina nodosaria and Dimorphina tuberosa will have to rest upon the arrangement of the anterior chambers. If these are alternating and very obliquely set, and if the shell is comparatively stoutly built with two methods of shell

1 D'Orbigny, A. D., Foraminifères fossiles du bassin tertiaire de Vienne, 1846, p. 221, Pl. XII, figs. 21-22.

2 Annales des sci. nat., vol. 7, 1826, p. 264, No. 1, modèle 60 .

3 Trans. Linnæan Soc. London, vol. 27, 1869, p. 249, Pl. XLII, figs. 39, a, b.

4 Idem, Pl. XL, figs. 18, a, b.

5 Jones, T. R., Parker, W. K., and Brady, H. B., Foraminifera of the Crag, pt. 1: Paleont. Soc., vol. 19, 1866, Pl. I, figs. 61 and perhaps $66(=D$. compacta). 
growth, the species must be called Dimorphina tuberosa. If, however, the later chambers become elongate and are set in a manner approaching that of Nodosaria, the species should be regarded as Polymorphina nodosaria. Some distinction can be made between the earlier and later segments of the two related forms, but in the writer's opinion this can not be safely used as a means of distinguishing the two species. Two specimens obtained from the Pliocene at Timms Point, San Pedro, differ from Dimorphina tuberosa chiefly in their greater elongation and in the more nodosarian character of their anterior portions.

Distribution.-Miocene and Pliocene only. Very rare in all late Tertiary deposits.

\section{Polymorphina oblonga D'Orbigny.}

Plate XX, figures 10-12.

Polymorphina oblonga D'Orbigny, 1846, Foram. foss. Vienne, p. 232, Pl. XII, figs. 29-31.

Polymorphina oblonga Brady, 1884, Challenger Rept., vol. 9, p. 569, Pl. LXXIII, figs. 2-4.

Description.-Test elongate, slightly compressed, about eight visible segments, smooth, more or less inflated, with strongly depressed septa. 'The species is entirely different from Polymorphina oblonga Williamsun, which is a compressed variety of Polymorphina lactea.

Distribution.-Tertiary to Recent. The writer found this species in dredgings off the Hawaiian Islands at a depth of 865 fathoms, but it is regarded by Brady as a shallow-water form and is rare below 500 fathoms. As a fossil it is not common. Brady, Parker, and Jones do not mention its occurrence in the Crag Pliocene. D'Orbigny's specimens came from the Miocene of the Vienna Basin.

\section{Polymorphina problema D'Orbigny.}

Plates XX, figures 1-6; XXI, figures $8, a, b$.

Polymorphina problema D’Orbigny, 1826, Annales des sci. nat., vol. 7, p. 266, No. 14 , modèle 61.

Guttulina problema D'Orbigny, 1846, Foram. foss. Vienne, p. 224, PI. XII, figs. 26-28.

Guttulina austriaca D'Orbigny, 1846, Foram. foss. Vienne, p. 223, P1. XII, figs. 23-25.

Polymorphina problema Brady, 1884, Challenger Rept., vol. 9, p. 568, Pl. LXXII, fig. 20 ; Pl. LXXIII, fig. 1.

Polymorphina problema Jones, 1896, Foram. Crag, pt. 3: Paleont. Soc., vol. 50, pp. 267-268; Pl. I, fig. 64; Pl. V, fig. 23; Pl. VI, fig. 12.

Description.-Test less elongate than Polymorphina oblonga D'Orbigny but with globose segments stoutly built and with numerous inflated segments that are irregularly crowded together. The species 
is closely related to Polymorphina communis, but that form has fewer chambers and less depressed septa, and its anterior end is more acuminate. The test of $P$. problema is extremely variable in its segmentation.

Distribution.-Lower Jurassic (Lias) to Recent. A shallow-water species of world-wide distribution, but not as a rule very abundant, perhaps less so than its congener Polymorphina communis, from which it can be distinguished only with difficulty. It is rather rare in the Pliocene at San Pedro, and only one specimen was discovered by the writer in the Pleistocene at Santa Barbara, in the higher hill series.

\section{Polymorphina soldanit D'Orbigny.}

Plate XIX, figure 8.

Polymorphina soldanii D’Orbigny, 1826, Annales des sci. nat., vol. 7, p. 265, No. 12. Polymorphina soldanii Brady, Parker, and Jones, 1869 (1870), Trans. Linn. Soc. London, p. 235, Pl. XI., fig. 20.

Description.-The test of Polymorphina soldanii D'Orbigny resembles Polymorphina oblonga and Polymorphina uvæformis Reuss, but, as Brady, Parker, and Jones point out, both of these have a central erect radiate aperture, whereas that of Polymorphina soldanii is originally drawn obliquely. This difference is in itself hardly sufficient to serve as a means of distinction between this form and allied species, but Polymorphina soldanii is also shorter and less fusiform than either of the other species. The San Pedro specimens approach Polymorphina nodosaria and Dimorphina tuberosa in their general contour but are shorter and more inflated in their chambering and have greater spiral development.

Distribution.- The Miocene chalk of Mecklenburg, the Miocene of the Vienna Basin, and the recent shore sands of the Adriatic appear to be the only recorded horizons. A few forms that appear to belong to this species were found in the Pliocene of San Pedro.

\section{Polymorphina sororia (Reuss).}

Plate XXI, figures $4, a-e, 5, a, b$.

'Polymorphina (Guttulina) sororia Reuss, 1863, Bull. Acad. roy. Belgique, 2d ser., vol. 15, p. 151, Pl. II, figs. 25-29.

Polymorphina sororia Jones, 1896, Foram. Crag, pt. 3: Paleont. Soc., vol. 50, p. 257, Pl. VI, fig. 13.

Description.-Test broad in middle and rounded below, with segments only slightly compressed; suture lines not deeply set as in Polymorphina communis D'Orbigny. There are but few chambers, obliquely set, appearing faintly in reflected light. The ultimate end is obtuse, and the whole form appears egg-shaped. 
Distribution.-This is a typical Tertiary species, but it has been recorded as occurring in the chalk of Taplow, in the Pliocene of England, and in the Oligocene. One unusually large specimen from the Pliocene of San Pedro measures more than 1 millimeter in diameter.

According to Brady the Challenger dredged this species from two stations west of Ireland in the north Atlantic, at 808 and 1,443 fathoms, and near the Cape of Good Hope at 1,375 fathoms. It has also been found in dredgings off Sierra Leone at 367 fathoms. The species is rather rare, both recent and in fossil condition. Its nearest relative is Polymorphina communis D'Orbigny.

Polymorphina trilocularis n. $\mathrm{sp}$.

Plate XX, figures $15-18$.

Description.-Test very minute and smooth, consisting of three elongated oval segments, two of which are equilateral and symmetrical; the central chamber extends halfway below the base of the two side chambers.

The form resembles Polymorphina compress $a$ in its young stages but lacks the compression of its segments, and the two lateral chambers are equal and placed symmetrically enwrapping the primordial segment. Aperture radiate, subcentral. Its greatest length is 0.75 millimeter, and its breadth, 0.28 millimeter. The form is rare in the Pliocene at Timms Point, San Pedro.

\section{Genus UVIGERINA.}

\section{Uvigerina ANGULOSA Williamson.}

Plate XXII, figures 2. a-f.

TVigerina angulosa Williamson, 1858, Recent Foram. Great Britain, p. 67, PI. V, fig. 140.

Uvigerina angulosa Brady, 1884, Challenger Rept., vol. 9, p. 576, PI. LXXIV, figs. $15-18$.

Uvigerina angulosa Goes, 1894, Kongl. Svenska Vetenskaps-Akad. Handl., Bd. 25, No. 9, p. 51, Pl. IX, figs. 502-509.

Uvigerina angulosa Jones, 1896, Foram. Crag, pt. 3: Paleont. Soc., vol. 50, p. 277, Pl. VII, fig. 26.

Description.-Test subovate, with pointed extremities. Cross section triangular; margins approaching carinate condition; surface smooth, slightly striate (?) in some specimens; aperture circular at end of prolongation of ultimate segment. Segments numerous, separated by depressed straight irregular septal lines.

Distribution.-Miocene to Recent. Found to-day in all seas and at all depths. Not common in the Pliocene of San Pedro. 


\section{Uvigerina asperula Czjzek.}

Plate XXIII, figures 11-13.

Uvigerina asperula Czjzek, 1847, Haidinger's Naturw. Abhandl., vol. 2, p. 146, Pl. XIII, figs. 14, 15.

Uvigerina asperula Rrady, 1884, Challenger Rept., vol. 9, p. 578, P1. LXXV, figs. 6-8.

Description.-Test moderately elongate or ovate; individuals vary in length, breadth, and general outline; surface beset with minute spines, which are in a few specimens arranged in parallel lines; distal end in some specimens apiculate; anterior extremity provided with long tubular neck. Some specimens have the final segment nearly smooth.

Distribution.-Miocene to Recent. Rare in the Pliocene at San . Pedro. A rather common species to-day, its bathymetric range in the Atlantic being from 435 to 1,675 fathoms.

\section{Uvigerina CaNariensis D'Orbigny.}

Plate XXII, figures 1, a-c.

Uvigerina canariensis D'Orbigny, 1839, Foram. Canaries, p. 138, Pl. I, figs. 25-27.

Uvigerina urnula D'Orbigny, 1846, Foram. foss. Vienne, p. 189, PI. XI, figs. 21-22.

Uvigerina canariensis Brady, 1884, Challenger Rept., vol. 9, p. 573, Pl. LXXIV, figs. 1-3.

Uvigerina canariensis Goes, 1894, Kongl. Svenska Vetenskaps-Akad. Handl., Bd. 25, No. 9, p. 52, Pl. IX, figs. 489-493.

Uvigerina canariensis Bagg, 1905, Bull. U. S. Geol. Survey No. 268, p. 38, Pl. VI, fig. 1.

Description.-Test irregularly triserial and elongate, built of projecting globose segments, which are separated by. well-defined septal depressions. The surface of the shell is perfectly smooth, and is typical of uvigerinine forms without ornament.

Distribution.-Miocene to Recent. Widely distributed at all depths in existing oceans. Goes's specimens came from the Azores, where it is abundant at a depth of 530 meters. This species is common in the California Miocene and not at all uncommon in the Pliocene of San Pedro.

\section{UVigerina PYgmaA D'Orbigny.}

Plates XXII, figures $3, a, b$.

Uvigerina pygmxa D’Orbigny, 1826, Annales des sci. nat., vol. 7, p. 269, P1. XII, figs. 8,9 ; modèle 67 .

Uvigerinx pygmæa D'Orbigny, 1846, Foram. foss. Vienne, p. 190, Pl. XI, figs. 25, 26.

Uvigerina pygmæa Brady, 1884, Challenger Rept., vol. 9, p. 575, Pl. LXXIV, typical figs. 11, 12; elongate forms, figs. 13, 14.

Uvigerina pygmæa Goes, 1894, Kongl. Svenska Vetenskaps-Akad. Handl., Bd. 25, No. 9, p. 51, Pl. IX, figs. 496-501.

Uvigerina pygmæa Bagg, 1905, Bull. U. S. Geol. Survey No. 268, p. 38, Pl. VII, fig. 2. Uvigerina pygmæa Bagg, 1898, Bull. Am. Paleontology, vol. 2, No. 10, p. 326, Pl. XXII (2), fig. 3.

Description.-The test of Uvigerina pygmæa is large and stoutly built, consisting of numerous segments separated by irregular oblique 
septa which are depressed. The surface is covered by pronounced vertical riblets, some of which are interrupted, but others extend the entire length of the shell. The aperture is phialine in the raised end of the tubular neck. The distal end is nonacuminate, and the general outline shows considerable variation in different specimens.

Distribution.-Miocene to Recent. Cosmopolitan; bathymetric range unrestricted. Not common in the Pliocene of San Pedro.

\title{
Uvigerina tenuistriata Reuss.
}

\author{
Plate XXIII, figures 9, 10, a, b.
}

Uvigcrina tenuistriata Reuss, 1870, Sitzungsber. Akad. Wiss. Wien, vol. 62, p. 485. Uvigerina tenuistriata Schlicht, 1870, Foram. Pietzpuhl, Pl. XXII, figs. 34-36.

Uvigerina tenuistriata Bagg, 1905, Bull. U. S. Geol. Survey No. 268, p. 39, Pl. VII, fig. 3.

Description.-Test similar to Uvigerina pygmæa D'Orbigny, but the surface is covered by fine strix and the form is more slender, tapering to near primordial segment. The septa are less depressed than in its congener, and the ultimate segment terminates in a rather extended tubulate neck.

Distribution.-Miocene to Recent. Abundant in shallow waters to-day. Rather common in the Miocene of California but rare in the Pliocene at San Pedro.

\section{Family GLOBIGERINID $A$.}

\section{Genus GLOBIGERINA.}

\section{Globigerina BUlloides D'Orbigny.}

Plate XXIII, figures 2-8.

Globigerina bulloides D'Orbigny, 1826, Annales des sci. nat., vol. 7, p. 277, No. 1, modèles 17 and 76.

Globigerina bulloides Jones, 1895, Foram. Crag, pt. 2: Paleont. Soc., vol. 49, pp. 280285, Pl. II, figs. 1, 2.

Globigerina bulloides Goes, 1894, Kongl. Svenska Vetenskaps-Akad. Handl., Bd. 25, No. 9, p. 83, Pl. XIV, figs. 754-762.

Globigerina bulloides Flint, 1899, Recent Foram.: Rept. U. S. Nat. Mus. for 1897, p. 321 , pl. 69 , fig. 2 .

Globigerina bulloides Bagg, 1905, Bull. U. S. Geol. Survey No. 268, p. 41, Pl. VII, fig. 7.

- Description.-Test composed of nearly globular segments built on a trochoid spiral type. The ultimate volution usually shows upon the inferior surface four segments which open into a common aperture in the depressed umbilicus. The superior surface shows all the volutions, usually three, and these rapidly enlarge. The surface is punctate and often roughened; the shell substance is white or gray. The specimens obtained at San Pedro are large, many of them measuring 0.56 millimeter in diameter. 
A complete list of references for this species would be very extensive. Probably one of the best is the synonymy given in the monograph on the Foraminifera of the Crag. ${ }^{1}$ The illustrations used by Goes in his excellent monograph of Arctic and Scandinavian Foraminifera cited above are reproduced in the accompanying plates.

Distribution.-According to Terquem, ${ }^{2}$ the earliest appearance of Globigerina bulloides is in Devonian rocks. The same author states that it is also present in the European Jurassic. It is abundant in the Chalk and is present in all succeeding formations. Globigerina cretacea largely supplants this species in the Cretaceous, especially in the chalk beds. It is abundant in the Pliocene of San Pedro and the Miocene of California and was also obtained from the bluffs of Pleistocene strata at Santa Barbara. This species is the most abundant type in all Globigerina ooze, though in some localities it is not typically developed. It is the most important pelagic foraminifer in existing oceans and occurs at all depths and in all oceans.

Globigerina ooze.-Probably the first specimens of Globigerina ooze were those obtained by Lieut. Berryman, United States Navy, from the north Atlantic, and described by Ehrenberg as early as 1853. Globigerina ooze is so abundant in the oceans of to-day that if all deposits containing from 10 to 15 per cent of the ooze were included it would be the most extensive marine deposit on the globe. It covers about $49,520,000$ square miles, and reaches its maximum development in the Atlantic Ocean, though it also covers more than $14,000,000$ square miles of the Pacific. It was abundant in all the dredgings made by the U.S. S. Albatross off the Hawaiian Islands, so far as they were examined by the writer.

In the reports of the Challenger expedition the term "Globigerina ooze" was applied only to those deposits which contained 30 per cent of Globigerina.

A complete list of the forms dredged by the Challenger follows:

Globigerina æquilateralis Brady. bulloides D'Orbigny. conglobata Brady. cretacea? D'Orbigny. digitata Brady.

$$
\begin{array}{|l}
\text { Globigerina dubia Egger. } \\
\text { dutertrei Brady. } \\
\text { inflata Brady. } \\
\text { rubra D'Orbigny. } \\
\text { sacculifera Brady. }
\end{array}
$$

This list might also include Orbulina universa D'Orbigny, which belongs to the same generic group. Most of these species are now limited to warm tropical waters, but some are found in cold waters. The deposits therefore vary with latitude, or, more exactly, depend on the polar or tropical origin of oceanic currents.

The color of this ooze is white, gray, or brown, depending largely on the nature of the sediment found with the snow-white Globigerina. 
The tropical forms are large, many being visible to the naked eye, and they range in depth from 400 to 2,925 fathoms, but the Globigerina ooze is most abundant at about 2,000 fathoms. The amount of carbonate of lime in the shells is inversely proportional to the depth, being 30.15 per cent at 2,575 fathoms and 96.80 per cent at 425 fathoms, according to the Challenger investigations.

The total average composition of 118 oozes, as determined by the Challenger expedition, is as follows:

Average composition of Globigerina oozes.

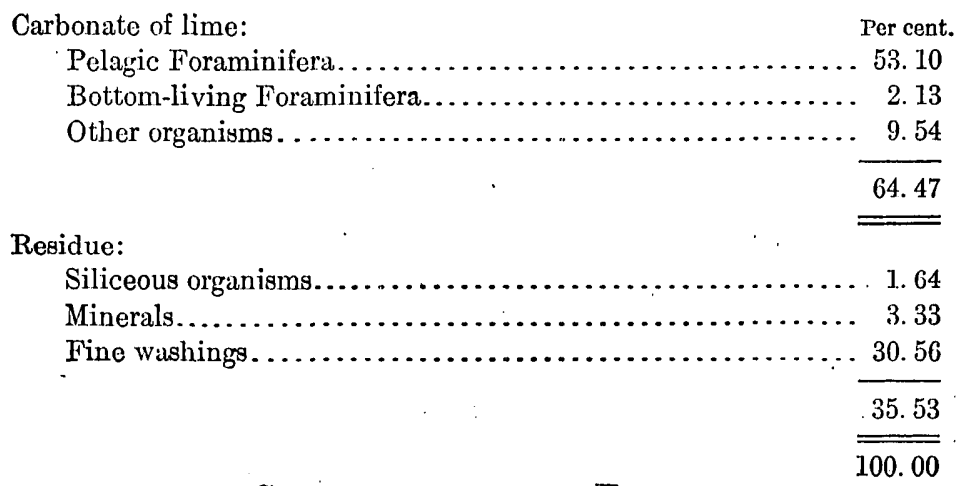

Globigerina DUbia Egger.

Plate XXII, figures 4, a-d.

Globigerina dubia Egger, 1857, Neues Jahrb.; p. 281, P1. IX, figs. 7-9.

Description.-Globigerina dubia has a stoutly. built test' of large dimensions and is really a varietal modification of Globigerina bulloides D'Orbigny. Many specimens have 14 or 15 segments, which are distinctly rotaline in development and which have a deeply sunken umbilicus upon the inferior surface. Development of five to six segments upon the inferior surface and greater inflation of the segments than in similar forms perhaps afford the best means of recognizing this species.

Distribution.-Miocene to Recent. Not very common in the Pliocene at San Pedro.

\section{Genus ORBUIINA.}

\section{Orbulina universa D'Orbigny.}

Plate XXIII, figure 1.

Orbulina universa D'Orbigny, 1839, Foram. Cuba, p. 3, Pl. I, fig. 1.

Orbulina universa Williamson, 1858, Recent Foram. Great Britain, p. 2, Pl. 1, fig. 4. Orbulina universa Bagg, 1905, Bull. U. S. Geol. Survey No. 268, p. 43, Pl. VIII, fig. 3.

Description.-Test globular, unicellular, in most specimens but rarely bilobate, with one segment incasing a Globigerina shell. In $45625^{\circ}-$ Bull. 513-12-6 
many living specimens the outer chamber is rough and even hispid, but in fossil types this feature is usually lost. The shell is perforato and of variable size.

Distribution.-Lower Jurassic (Lias) to Recent; possibly much earlier than the Jurassic. It is not rare in the Pliocene of San Pedro, but owing to its minute size and spherical shape it is easily floated off from washings and lost. It is exceedingly abundant in existing oceans at all depths. As a pelagic type it exceeds in abundance even Globigerina bulloides D'Orbigny.

Family ROTALIID屟.

\section{Subfamily ROTALIIN $A$.}

Genus DISCORBINA.

\section{Discorbina BERTheloti (D'Orbigny).}

Plate XX́XIII, figures 10, 11, a, b.

Rosalina bertheloti D'Or'igny, 1839, Foram. Canaries, p. 135, Pl. I, figs. 28-30.

Discorbina bertheloti Brady, 1884, Challenger Rept., vol. 9, p. 650, Pl. LXXXIX, figs. 10-12.

Discorbina bertheloti Brady, Parker, and Jones, 1888, Trans. Zool. Soc. London, vol. 12 , No. 7, p. 227, Pl. XLVI, figs. 7, 8.

Discorbina berthelotiana Goes, 1894, Kongl. Svenska Vetenskaps-Akad. Handl., Bd. 25, No. 9, p. 93, Pl. XV, fig. 790.

Description.-Test very strongly compressed and thin, with the spiral surface almost flat and the inferior more vaulted and limbate. Both surfaces show complete convolutions, but they are more distinct on the superior surface. The final segment is very large, and the species is provided with a thin, finely perforate shell, two features which distinguish it from Truncatulina lobatula, which otherwise it very much resembles. A variety of the type provided with carinate periphery is known as $D$. bertheloti var. bajonica Hantken. Goes describes this species but gives the specific term as berthelotiana. This is evidently the same form as that given by D'Orbigny and also described by Parker and Jones as Discorbina turbo var. parisiensis var. berthelotiana, both terms being misspellings for bertheloti.

Distribution.-Pliocene of San Pedro (rare) and Recent. Widely distributed in existing oceans but nowhere abundant. Typical of shoal water of north boreal provinces and most common at depths of less than 500 fathoms. 


\section{Discorbina gLOBUlaris (D'Orbigny).}

Plate XXIV, figure 15.

Rosalina globularis D'Orbigny, 1826, Annales des sci. nat., vol. 7, p. 271, P1. XIII, figs. 1-4, modèle 69 .

Discorbina turbo var. globularis Carpenter, Parker, and Jones, 1862, Introduction Foram., pp. 204, 311, Pl. III, fig. 1 (shows pseudopodia).

Discorbina globularis Brady, 1884, Challenger Rept., vol. 9, pp. 627, 643, Pl. LXXXVI, figs. 8, 13.

Discorbina globularis Jones, 1895, Foram. Crag, pt. 2: Paleont. Soc., vol. 49, p. 292, Pl. VII, figs. 28 a-c.

Discorbina globularis Flint, 1899, Recent Foram.: Rept: U. S. Nat. Mus. for 1897, p. 327 , pl. 72 , fig. 2 .

Description.-Flint gives the following description of this form:

Discoidal, thick, the superior face quite convex, the inferior only slightly so; segments somewhat inflated, finely perforated, hyaline, all visible superiorly, only the last convolution inferiorly; sutures a little depresised; apertuire large and irregular at the umbilical margin of the last segment.

Distribution.-Eocene to Recent. This species has a wide range in present oceans but is most common in temperate and cold waters. It is a shallow-water type, the Challenger expedition obtaining no specimens at depths greater than 450 fathoms. It is common in the Pleistocene of Santa Barbara.

\section{Discorbina 'TURBo (D'Orbigny).}

Rotalia (Trochulina) turbo D’Orbigny, 1826, Annales des sci. nat., vol. 7, p. 274, No. 39 , modèle 73.

Discorbina turbo Jones, 1895, Foram. Crag, pt. 2: Paleont. Soc., vol. 49, p. 291, Pl. VII, fig. 29.

Description.-Test trochoid, superior surface conical, inferior face almost complanate; segments very numerous, visible on spiral side, but only 5 to 10 show on the inferior surface. The septal lines are wide and strongly curved on the conical side but narrow and depressed on the reverse surface. The periphery is sharp, and the aspect of the shell, as seen from the side, triangular.

Distribution.-Cretaceous (Maestricht chalk) to Recent. This species, although it is the type for the genus Discorbina, is rare in present oceans. - It was obtained at only one station (223 fathoms, off Mauritius) by the Gazelle, and at only four places in very shallow water by the Challenger expedition. It is common in the lower strata of the Pleistocene at Santa Barbara, along the beach. 


\title{
Discorbina vilardeboana (D'Orbigny).
}

\author{
Plate XXVIII, figures 9 , a-c.
}

Rosalina vilardeboana D’Orbigny, 1839, Foram. Amérique mérid., p. 44, Pl. VI, figs. 13-15.

Discorbina vilardeboana Brady, 1884, Challenger Rept., vol. 9, p. 645, P1. LXXXVI, figs. 9, 12; Pl. LXXXVIII, fig. 2.

Discorbina vilardeboana Goes, 1894, Kongl. Svenska Vetenskaps-Akad. Handl., Bd. 25, No. 9, p. 95, P1. XVI, fig. 796.

Description.-This species resembles both Discorbina araucana (D'Orbigny) and Discorbina rosacea (D'Orbigny). It can not be easily distinguished from either, but the test is minute, the perforations small, and the peripheral margin not acute. Fewer chambers in the ultimate convolution show on the inferior surface than in the other forms. These chambers are lobate, and are separated by almost straight depressed septa. The later segments are of much larger size. Under the tumid border of the large final chamber and extending toward the umbilicus is the elongate aperture slit.

Distribution.-A few specimens of this form were found in the beach bluffs at Santa Barbara, in the Pleistocene. As a living form it is commonly present with Discorbina araucana (D'Orbigny).

\section{Genus TRUNCATUIINA.}

\section{Truncatulina lobatula (Walker and Jacob).}

Plate XXIV, figures 9-1.4.

Nautilus lobatulus Walker and Jacob, 1798, Adam's Essays, Kanmacher's ed., p. 642, Pl. XIV, fig. 36 .

Truncatulina lobatula D'Orbigny, 1846, Foram. foss. Vienne, p. 168, Pl. IX, figs. 18-23.

Truncatulina boueana D'Orbigny, 1846, Foram. foss. Vienne, p. 169, Pl. IX, figs. 24-26.

Truncatulina lobatula Williamson, 1858, Recent Foram. Great Britain, p. 59, Pl. V, figs. 121-1.23.

Truncatulina lobatula Jones, 1897, Foram. Crag, pt. 4: Paleont. Soc., vol. 51, pp. 304308, Pl. II, figs. 4-10 (1866); Pl. IV, fig. 19.

Truncatulina lobatula Bagg, 1905, U. S. Geol. Survey No. 268, p. 46, Pl. IX, fig. 1.

Description.-Test plano-convex, moderately vaulted on inferior surface, which shows only the segments of final convolution, and planate upon the superior.surface, which shows all the convolutions (about three). The segments as viewed from inferior surface are lobate with depressed septa, straight or but slightly curved. The upper face shows strongly arching septa, in some specimens with subcarinate periphery. The aperture is an arched slit at or near the margin of the ultimate segment, but extending back from the periphery toward the umbilicus. The species is the most important of the genus Truncatulina and holds the same place in this group that 
Globigerina bulloides holds among its congeners. When adherent, as it is not uncommonly, it may have a subarenaceous structure and be dark in color. It has, especially in the young forms, a semihyaline texture, which gradually changes to an opaque white, with large perforations scattered over the entire surface.

Distribution.-Carboniferous to Recent. The Miocene of California contains a great many Truncatulina lobatula, and there the shells are coarsely porous. In the Pliocene of San Pedro the forms are numerous but not more abundant than Truncatulina variabilis, which is unusually plentiful. The species is common in the upper Pleistocene strata at Santa Barbara.

It occurs abundantly in the English Crag, being present in every zone. Although common in Cretaceous strata, it is more abundant in Tertiai'y and Recent material.

\section{Truncatulina ReFulgens (Montfort).}

Cibicides refulgens Montfort, 1.808, Conchyl. syst., vol. 1, p. 1.22, $31^{\mathrm{e}}$ genre.

Truncatulina refulgens Brady, 1884, Challenger Rept., vol. 9, p. 659, Pl. XCII, figs. 7-9.

Truncatulina refulgens Sherborn and Chapman, 1886, Jour. Roy. Micr. Soc., 2d ser., vol. 6 , p. 756, Pl. XVI, figs. 13 , a-c.

Truncatulina reful!ens Goes, 1894, Kongl. Svenska Vetenskaps- $\Lambda$ kad. Handl., Bd. 25, No. 9, p: 89, Pl. XV, figs. 775, 776.

Truncatulina refulgens Jones, 1896, Foram. Crag, pt. 3: Paleont. Soc., vol. 50, p. 302, Pl. V, fige. 31a, 31.b.

Description.-The following description is quoted from Jones:

Shell free or parasitic, regular; conical or plano-convex. Oral surface conical or dome-shaped, aboral surface flat or slightly concave; chambers long, arcuate, somewhat inflated. Foramina inconspicuous.

Distribution.-Eocene to Recent. Living forms confined to tempcrate zones and found usually at small depths, though occurring down to 2,400 fathoms. It is rare in the Pliocene at San Pedro.

\section{Trtjncatulina ungeriana (D'Orbigny).}

Plate XXV, figures 1-3.

Rotalina ungeriana D'Orbigny, 1846, Foram. foss. Vienne, p. 157, Pl. VIII, figs. 16-18. Iruncatulina ungeriana Brady, 1884, Challenger Rept., vol. 9, p. 664, P1. XCIV. figs. $9, \mathrm{a}-\mathrm{c}$.

Truncatulina ungeriana Bagg, 1898, Bull. U. S. Geol. Survey No. 88, p. 66.

Description.-Test large, rotaliform, circular, coarsely porous; both sides moderately convex, unequal; depressed slightly on the inferior side at the umbilicus: consisting of three convulutions. The last volution usually has about 10 limbate segments, but may have 12 . The septa are arched and are visible externally. The aperture is a median semilunar slit. In D'Orbigny's original figure the species is 
shown to be moderately sharp at the periphery. The vaulting is unequal on the two sides and the septa are more arcuate on the lower surface. The umbilicus is better exposed on the superior surface.

One perfect specimen from San Pedro shows eight segments in the final convolution. The shell walls are very coarsely porous.

Distribution.-Cretaceous to Recent. Very rare in Pliocene of San Pedro. The species is rather common in the New Jersey Cretaceous, the Cretaceous of England, and the Eocene of London, and is present at all succeeding horizons. It is fairly common in the north Atlantic, but less abundant in the south Atlantic. It has wide bathymetric and geographic range.

\title{
Truncatulina variabilis D'Orbigny.
}

\author{
Plates XXIV, figures 1-4; XXV, figures $4,5$.
}

Truncatulina variabilis D'Orbigny, 1826, Annales des sci. nat., vol. 7, p. 279, No. 8 . Truncatulina variabilis Jones, 1896, Foram. Crag, pt. 3: Paleont. Soc., vol. 50, p. 309, Pl. VI, fig. 23.

Description.-This is only an irregular. type of Truncatula lobatula. The San Pedro specimens are much like the figure given in the Crag monograph. The species is relatively abundant and the specimens are of various sizes, but the shells all tend to. become elongate in a biserial manner and are without lateral processes.

Distribution.-Lower Cretaceous to Recent. Its present geographic and bathymetric range correspond with that of Truncatulina lobatula. It is common in the Pliocene at San Pedro and equally abundant in the Pleistocene at Santa Barbara, where it is most numerous in the upper beds.

\section{Truncatulina wuellerstorfi (Schwager).}

Plate XXV, figures 10, a-c, 11, a-c.

Anomalina wucllerstorfi Schwager, 1866, Novara-Exped., Geol., pt. 2, p. 258, P1. V.II, figs. 105-107.

Truncatulina wuellerstorfi Brady, 1884, Challenger Rept., vol. 9, p. 662, Pl. XCIII, figs. $8,9$.

Planorbulina wuellerstorfi Goes, 1894, Kongl. Svenska Vetenskaps-Akad. Handl., Bd. 25, No. 9, p. 89, Pl. XV, fig. 777.

Description.-Test plano-convex or nearly so; superior face somewhat convex, inferior nearly flat, margin acute. Segments strongly curved, narrow, often crescent-like. The form is thin and outspread, and according to Brady occupies an intermediate position between Anomalina ariminensis (D'Orbigny) and the thicker Truncatulina lobatula (Walker and Jacob).

Distribution.-The species is common to-day in deep-sea oozes. A modification of the type appears in the New Jersey Cretaceous, and the species is also known in the Miocene of California and the Pliocene 
of Kar Nikobar (Schwager). It is very rare in the Pleistocene of Santa Barbara.

\section{Genus ANOMAIINA.}

Anomalina ammonoides (Reuss).

Plate XXVI, figures 7-10, b.

Rosalina ammonoides Reuss, 1845, Verstein. böhm. Kreid., pt. 1, p. 36, P1. XIII, fig. 66; Pl. VIII, fig. 53.

Anomalina ammonoides Bagg, 1905, Bull. U. S. Geol. Survey No. 268, p. 47, PI. IX, fig. 4.

Description.-Test nautiloid, coarsely porous, small, compressed; lateral surfaces nearly equally convex; depressed at the umbilici. The peripheral margin is round. The aperture is a nearly median arched slit on the inner surface of the ultimate segment. The diameter is from 0.5 to 0.8 millimeter. There are more chambers in the final convolution than in Anomalina grosserugosa (Gumbel) (9 in the specimens from San Pedro).

Distribution.-Anomalina ammonoides is found in the Upper Cretaceous of New Jersey, in the Gault of England (Chapman), and in beds of every succeeding epoch. The species is present, though rare, in dredgings from the vicinity of the Hawaiian Islands (Bagg). The Challenger dredged this species at only one station in the north Atlantic, at 435 fathoms (Brady). It seems to be much more common in the southern oceans, where it occurs at depths as great as 1,350 fathoms. It is very rare at Timms Point, San Pedro.

Anomalina grosserugosa (Gumbel).

Plate XXVI, figures $1-6$.

Truncatulina grosserugosa Gumbel, 1868, Abhandl. Math.-phys. Cl. K. bayer. Akad. Wiss., vol. 10, p. 660, Pl. II, fig. 104, a, b.

Description.-Test less nautiloid than Anomalina ammonoides and with fewer chambers in each volution. Shell coarsely porous, with pores larger and more numerous on the inferior surface; both sides convex; umbilici distinct; peripheral margin round; chambers large, inflated; septa nearly straight; uperture nearly median. 'The San Pedro specimens show about seven chambers in the final volution, all of which are visible from the inferior aspect. All the volutions are visible from the superior surface.

Distribution.-Lower Cretaceous to Recent. Occurs in the north Atlantic at depths ranging from 450 to 1,000 fathoms, and also in the south Atlantic and the north and south Pacific. The species seems to be more common in the Tertiary than its congener Anomalina ammonoides. Anomalina badenensis D'Orbigny, from the Tertiary of the Vienna Basin, is probably a variety of this species. ${ }^{1}$ It is rare in the Pliocene sands of Timms Point, San Pedro.

1D'Orbigny, A. D., Foraminifères fossiles du bassin tertialre de Vlenne, 1846, p. 171, Pl. X, figs. 1-3. 


\section{Genus PULVINULINA.}

\section{Pulvinulina elegans (D'Orbigny).}

Plate XXVI, figures 11-15, c.

Rotalina (Turbinulina) elegans D'Orbigny, 1826, Annales des sci. nat., vol. 7, p. 276, No. 54.

Rotalina partschiana D'Orbigny, 1846, Foram. foss. Vienne, p. 153, P1. VII, figs. 28-30; Pl. VIII, figs. 1-3.

Pulvinulina elegans Jones, 1897, Foram. Crag, pt. 4: Paleont. Soc., vol. 51, p. 324, Pl. VII, fig. 32 .

Description:-Test biconvex but becoming trochoid from unsymmetrical chamber development, which results in all the convolutions being visible externally on the superior surface and makes only the final whorl discernible below. Periphery sharp, subcarinate; segments on upper surface numerous, separated by wide, strongly curving septal bands, depressed and obliquely set beneath. This species is a shallow-water type, but can hardly be distinguished from its counterpart, Pulvinulina partschiana (D'Orbigny), a deep-water type. It is also related to Pulvinulina karsteni (Reuss), a smaller, less symmetrical species.

Distribution.-Base of the Lower Jurassic (Lower Lias of Europe) to Recent. Of world-wide distribution and found at all depths, but especially developed in shoal waters. Goes records the species from the shores of Spitzbergen and Greenland. It is rare in the Pliocene of San Pedro.

\section{Pulvinulina punctulata' (D'Orbigny).}

Plate XXV, figures 6-9.

Rotalia punctulata D'Orbigny, 1826, Annales des sci. nat., vol. 7, p. 273, No. 25, modèle 12.

Pulvinulina punctulata Brady, 1884, Challenger Rept., vol. 9, p. 685, Pl. CIV, fig. 17. Pulvinulina punctulata Jones, 1897, Foram. Crag, pt. 4: Paleont. Soc., vol. 51, p. 319, Pl. II, figs. 22-24, in vol. 19.

Pulvinuliná punctulata Goes, 1894, Kongl. Svenska Vetenskaps-Akad. Handl., Bd. 25, No. 9, p. 96, Pl. XVI, figs. 797-800 (798 is typical).

Description.-This species is scarcely distinguishable from Put vinulina repanda (Fichtel and Moll), but its inferior surface is more or less punctate and roughened and the chambers, though inflated, are'separated by nonlimbate septa. The shells from the Crag and the Pliocene specimens from San Pedro are remarkable for their large size, the larger specimens being 1 to 2 millimeters in diameter.

Distribution.-Eocene to Recent, but most common in the Pliocene. Found in the glacial clays (post-Tertiary) of the Norwegian coast (Jones) and in the English Crag, and is not rare in the Pliocene at San Pedro. It appears to be less common and less widely dis- 
tributed than Pulvinulina repanda. The living forms inhabit depths ranging from a few fathoms to about 300 fathoms in the north Atlantic and occur also elsewhere.

\section{Pulvinulina Repanda (Fichtel and Moll).}

Plate XXIV, figures 5-8.

Nautilus repandus Fichtel and Moll, 1803; Test. micr., p. 35, Pl. III, figs. a-d.

Pulvinulina repanda Jones, 1897, Foram. Crag, pt. 4: Paleont. Soc., vol. 51, pp. 317-319, Pl. II, figs. 25-27. (In Paleont. Soc., vol. 19, 1866, it is described as Pulvinulina pulchella (D'Orbigny).)

Description.-Test discoidal but not circular in outline, for the ultimate segment is extended beyond the plane of the circular periphery. The final convolution is composed of six to eight chambers, which segments alone appear on the inferior surface. The superior surface is more vaulted, though not strongly so, and the entire chamber arrangement of each volution is visible. The segments are separated on the superior side by distinct and rather wide septal bands, but these are not elevated and apparently are not altogether due to shell thickening in depressed areas. The margin is limbate, and this character with its lack of punctate surface separates this common species from Pulvinulina punctulata. The peripheral margin is slightly lobulate, the ultimate chambers showing this feature most definitely. The umbilicus is strongly depressed upon the inferior surface.and the chambers are inflated between the depressed septa. These are straight or nearly straight from center to margin; on the superior surface they are gracefully and strongly curved backward. The shells may be very large and may show considerable variation in minor Pulvinulina characters. Large specimens are 1.5 millimeters in diameter. This species is figured by Williamson ${ }^{1}$ under the name Rotalina concamerata.

Distribution.-Cretaceous to Recent. Common down to 200 fathoms; rare at greater depths to 1,000 fathoms. Occurs in every zone of the English Crag wherever examined (Jones). 
Family NUMMULINID $Æ$.

\title{
Subfamily POLYSTOMELLIN $A$.
}

\section{Genus NONIONINA.}

\section{Nonionina DePressula (Walker and Jacob).}

\author{
Plates XXVI, figures 16, a-c; XXVIII, figures 7, 8.
}

Nautilus depressulus Walker and Jacob, 1798, Adam's Essays, Kanmacher's ed., p. 641, Pl. XIV, fig. 33.

Nonionina depressula Brady, 1884, Challenger Rept., vol. 9, p. 725, Pl. CIX, figs. 6, 7. Nonionina depressula Goes, 1894, Kongl. Svenska Vetenskaps-Akad. Handl., Bd. 25, No. 9 , p. 103 , Pl. XVII, figs. 825,826 .

Nonionina depressula Jones, 1897, Foram. Crag, pt. 4: Paleont. Soc., vol. 51, p. 347, Pl. II (1866), figs. 36, 37 (thick variety).

Description.-Test nautiloid or disk-shaped, with rounded margin, compressed but not umbilicate; chambers slightly limbate, separated by depressed, very slightly curved septa; septal face more or less rounded, showing aperture as narrow slit on inner margin; surface often granular, especially along septal planes. The configuration of this shell is almost identical with that of Polystomella striatopunctata (Fichtel and Moll), but the latter shows septal bridges which this form lacks.

Distribution.-Eocene to Recent. This species is found to-day in Arctic waters as far north as $82^{\circ} 33^{\prime}$, and it is very common off the British coasts. It is typically a shoal-water species, being found at depths of less than 50 fathoms. This form is interesting in that it is the only Nonionina which occurs in brackish waters and in estuaries. Nonionina depressula is rather common in the European Tertiary and appears in the Coralline Crag of England. It is rather rare in the Pliocene at Timms Point, San Pedro. Two specimens were obtained by the writer from the Pleistocene of Santa Barbara, in the lower strata along the beach.

\section{Nonionina scapiea (Fichtel and Moll).}

Plate XXVII, figures 1-3.

Nautilus scapha Fichtel and Moll, 1803, Test. micr., p. 105, Pl. XIX, figs. d-f.

Nonionina scapha Brady, 1884, Challenger Rept., vol. 9, p. 730, Pl. CIX, figs. 14, 15, and 16(?).

Nonionina scapha Jones, 1897, Foram. Crag, pt. 4: Paleont. Soc., vol. 51, pp. 339-343, Pl. II, figs. 44, 45 (var. N. labradorica), and woodcuts after Fichtel and Moll (figs. 27a, 27b).

Description.-The test of Nonionina scapha is oblong-ovate, and is strongly depressed at the umbilicus. The segments are numerous, arcuate, and more or less ventricose; they widen toward the periphery, which is rounded. The aperture is a crescentic slit on the inner 
margin of the ultimate segment. The septal face is large and ovate, and, in N. scapha var. Zabradorica, cordate.

Distribution.-This species is present in the Gretaceous of both England and the United States and is abundant in late Tertiary strata. It is common in the English Crag. and is present, though not common in the Pliocene of San Pedro. It is common in all the strata of Pleistocene age at Santa Barbara. The form is to-day widely diffused. The writer found it to be the most common Nonionina in the dredgings from the Hawaiian Islands region. It is most abun dant in shoal waters. The species is present in the cold waters of the far North, but specimens from such waters are thick and exhibit considerable variation from the more slender minute specimens of temperate zones.

\section{Nonionina stelligera D'Orbigny. .}

Plate XXVII, figures 7, 8 .

Nonionina stelligera D'Orbigny, 1839, Foram. Cånaries, p. 128; Pl. III, figs. 1, 2 ("stellifera" on plate).

Nonionina stelligera Brady, 1864, Trans. Linn. Soc. London, vol. 24, p. 471, Pl. XLVIII, fig. 19.

Polystomella crispa (Linnæus) var. (Nonionina) stelligera (D'Orbigny) Parker and Jones, 1865, Philos. Trans., vol. 155, p. 404, Pl. XIV, figs. 40, 41 (Arctic).

Nonionina stelligera Brady, 1884, Challenger Rept., vol. 9, p.. 728, Pl. CIX, figs. 3-5. Nonionina stelligera Goes, 1894, Kongl. Svenska Vetenskaps-Akad. Handl., Bd. 25, No. 9, p. 104, Pl. XVII, figs. 827, 828.

Description.-This is a small, compressed Nonionina resembling Nonionina asterizans (Fichtel and Moll), but it is more delicate than that species and its exogenous umbilical covering radiates from the umbilicus along the depressed sulci of the septa, whereas in $N$. asterizans the umbilicus is covered only over the central area, having a slight central zone uncovered. The aperture is a narrow slit upon the inner surface of the ultimate segment. The five to nine segments in the final convolution are lobate, and the periphery is round, in both of which features this form resembles Nonionina depressula (Walker and Jacob).

Distribution.-Eocene to Recent. This is preeminently a coldwater type, although D'Orbigny's original specimens were obtained from the Canaries in shore sands. It occurs in Arctic waters at very shallow depths to-day. It is abundant near the top of the hills in the Pleistocene at Santa Barbara, but rare along the beach bluffs below. 


\section{Nonionina umbilicatula (Montagu).}

Plate XXVII, figures 4-6.

Nautilus umbilicatula Montagu, 1803, Test. Brit., p. 191; Supplement, p. 78, Pl. XVIII, fig. 1.

Nonionina soldanii D'Orbigny, 1846, Foram. foss. Vienne, p. 109, Pl. V, figs. 15, 16. Nonionina umbilicatula Brady, 1884, Challenger Rept., vol. 9, p. 726, PI. CIX, figs.8, 9 . Nonionina umbilicatula Goes, 1894, Kongl. Svenska Vetenskaps-Akad. Handl., Bd. 25, No. 9, p. 103, Pl. XVII, figs. $823,824$.

Nonionina umbilicatula Jones, 1897, Foram. Crag, pt. 4: Paleont. Soc., vol. 51, pp. 345-347, Pl. V, fig. 32; woodcuts, p. 346, zoological type.

Description.-Test nautiloid, numerous segments, usually flush but with sunken umbilicus. The shell is small but stoutly built. It has more chambèrs and is more compressed laterally than Nonionina pompilioides.(Fichtel and Moll), and its umbilicus is more deeply sunken than that of Nonionina depressula (Walker and Jacob).

Distribution.-Eocene to Recent. Found in the Pleistocene at Santa Barbara: The type is essentially a deep-water form and is most common in warm waters. It is, however, abundant in the Norwegian seas at depths of 40 to 180 meters (Goes) and in the north Atlantic at depths of less than 450 fathoms. Parker and Jones ${ }^{1}$ state:

We have it in the mixed sands from the Norway coast (MacAndrew and Barrett). In the north Atlantic $N$. umbilicatula is common and of middle size on the marginal plateau off Ireland, at 78,90,223, and 415 fathoms; in the abyssal depths it is rare and small and at 1,776, rather common and middle sized at 1,950, rather common and small at 2,050 and 2,176 fathoms; and at 2,350 fathoms in the "boreal" part of the abyss it is rare and small; north of Newfoundland Bank, at 329 fathoms, and in Trinity Bay at 150 fathoms, it is very rare and small, cold water having as bad an influence on it as abyssal depth. This form, being flush-celled, is more thoroughly changed in character from the type than the feeble varieties found in shallow water, such as $P$. stelligera and $P$. depressula. In these the vesicularity of the chambers allows the formation of some rudiments of the retral processes, the overlying bridges, and the intervening fossettes, but in this deeper-sea variety the septal walls of the contiguous chambers become perfectly adapted, and their edges grow close together at the surface of the shell.

\section{Genus POLYSTOMELLA.}

Polystomelia cRIspa (Linnæus).

Plates XXVII, figures 13-20; XXVIII, figures 1-6.

Nautilus crispa Linnæus, 1758, Syst. Nat., 10th ed., p. 709, No. 235; 1.2th ed. (1767), p. 1162, No. 275; 13th (Gmelin's) ed., p. 3370, No. 3.

Polystomella crispa, D'Orbigny, 1846, Foram. foss. Vienne, pp. 125, 126, PI. VI, figs. 9-14.

Polystomella crispa Williamson, 1858, Recent Foram. Great Britain, pp. 40-42, Pl. III, figs. 78-80.

1 Foraminifera from the north Atlantic and Aretic occans: Pnllos. Trans., vol. 155, 1365, p. 405. 
Polystomella crispa Goes, 1894, Kongl. Svenska Vetenskaps-Akad. Handl., Bd. 25, No. 9, p. 102, Pl. XVII, figs. 820-821.

Polystomella crispa Jones, 1897, Foram. Crag, pt. 4: Paleont. Soc., vol. 51, pp. 353357, P1. II, figs. 40-43.

Description.--Test lenticular, involute, and nautiloid, showing only the final whorl in outer convolution, which is composed of numerous very narrow, strongly curved, and flexuose segments. Septal lines strong, raised slightly in border in front, with the central part and sometimes the posterior part depressed and even sculptured; segments marked by closely set septal bridges, which become more pronounced at their junction with preceding segments. These surface transverse crenulations make possible the immediate detection of Polystomella and separate the genus from Nonionina, which it resembles in its other structural features. The umbilicus is commonly granulose but not depressed, and this flush and roughened surface distinguishes the species from Polystomella macella (Fichtel and Moll), which is depressed at the umbilicus. The peripheral margin is sharp, and in some specimens carinate. Some varieties show tubercular or spinous processes projecting from the septal ridges. The apertures are multiple and are arranged in V-shaped series close to the surface of the antecedent convolution. The diameter of the test is very variable. Pliocene forms from San Pedro measure from 1 to 1.8 millimeters and show about 22 segments in the final convolution, but the number and size of the shells vary considerably.

Distribution.-Polystomella crispa is a very common Tertiary fossil. It appears to be first known in the Eocene of the Paris Basin and occurs at all succeeding horizons. It is abundant in the English Pliocene Crag and the Pliocene sands of San Pedro. The Pleistocene beach-bluff deposits of Santa Barbara contain a large number of Polystomella crispa, but the form is rather rare in the beds near the top of the hills above the beach. This species is to-day of worldwide distribution but is most frequently found in the comparatively shallow waters extending from the littoral zone down to 335 fathoms. It is characteristically a cold temperate and north Atlantic type, being replaced chiefly by Polystomella arctica Parker and Jones and P. striatopunctata (Fichtel and Moll) in Arctic waters and by Polystomella craticulata (Fichtel and Moll) in tropical waters. Just as these species of Polystomella characterize certain oceanic temperatures, so do the species of Nonionina which are so often found with that genus. Thus Nonionina scapha (Fichtel and Moll) and Nonionina umbilicatula (Montagu) are characteristic of warm tropical waters, Nonionina depressula (Walker and Jacob) is more common in temperate zones, and $N$. stelligera D'Orbigny inhabits Smith Sound, as far north as latitude $82^{\circ} 33^{\prime}$ and the waters along the shores of Spitzbergen. 


\section{Polystomella striatopunctata (Fichtel and Moll).}

Plate XXVII, figures 10-12.

Nautilus striatopunctatus Fichtel and Moll, 1798, Test. micr., p. 61, Pl. IX, figs. a-c. Polystomella striatopunctata Brady, Parker, and Jones, 1888, Trans. Zool. Soc. London, vol. 12 , pt. 7, p. 230, P1. XLIII, fig. xvii (17).

Polystomella striatopunctata Brady, 1884, Challenger Rept., vol. 9, p. 733, Pl. CIX, figs. 22, 23.

Polystomella striatopunctata Jones, 1897, Foram. Crag, pt. 4: Paleont. Soc., vol. 51, pp. 350-352, Pl. II (1866), figs. 38, 39.

Polystomella striatopunctata Goes, 1894, Kongl. Svenska Vetenskaps-Akad. Handl., Bd. 25, No. 9, p. 101, Pl. XVII, figs. 815(?), 816.

Description.-Test nautiloid, rather compressed, and showing only the final convolution symmetrically from both aspects. The periphery is neatly rounded and somewhat lobulated, and the umbilicus is depressed. The shell is comparable with Nonionina depressula, from which it can easily be distinguished by the retral processes, which are always well developed in Polystomella and which are absent in Nonionina. The shell is usually small, and the specimens collected by the writer are much smaller and more delicate than the common Polystomella crispa.

Distribution.-Eocene to Recent. This is one of the most abundant forms of Polystomella, both Recent and as a Tertiary fossil. The species exists at all depths and in all temperatures, being found in Arctic waters, in the Red Sea, and in the southern oceans. Its habitat is primarily shallow water, usually from shore line down to 100 fathoms. It is especially abundant in the upper English Crag and the Belgian Pliocene Crag and also as a Pleistocene fossil.

\section{Polystomella subnodosa (Von Munster).}

Plate XXVIII, figures $12, a, b$.

Robulina subnodosa Von Munster, 1838 (fide Romer), Neues Jahrb., p. 391, PI. III, fig. 61.

Polystomella subnodosa Brady, 1884, Challenger Rept., vol. 9, p. 734, P1. CX, fig. I. Polystomella subnodosa Goes, 1894, Kongl. Svenska Vetenskaps-Akad. Handl., Bd. 25, No. 9, p. 102, Pl. XVII, figs. 817-819.

Description.-Test biconvex, sharp; periphery subcarinate, umbilici turgid or slightly umbonate, septa somewhat depressed; septal bridges and fossettes similar to those of Polystomella striatopunctata (Fichtel and Moll). In the one small specimen from San Pedro the septal divisions are rather too pronounced and elevated for the type.

Distribution.-Oligocene to Recent. This is a rare living foraminifer and was dredged by the Challenger expedition at only two stations, at depths of a few fathoms in the south Pacific. It is also rare among the abundant Polystomella crispa forms at San Pedro and in the Pleistocene at Santa Barbara, where it occurs in the lower beach bluffs. 
PLATES. 



\section{PLATE I.}

$45625^{\circ}-$ Bull. 513-12-7 


\section{PLATE I.}

Figures 1-4. Biloculina bulloides D'Orbigny. (After Schlumberger.) 1, 2, 3, Lateral aspects; 4 , end view............................... 23

Figures 5-9. Aperture of Biloculinaringens (Lamarck). (After Schlumberger.)

All enlarged views to show detail................................

Figure 10. Biloculina bulloides D'Orbigny. (After Schlumberger.) Greatly

enlarged cross section to show structure.........................

Frgure 11. Biloculina ringens (Lamarck). (After Schlumberger.) Cross section, greatly enlarged.....................................

Figures 12-16. Five specimens of Biloculina ringens (Lamarck) from San

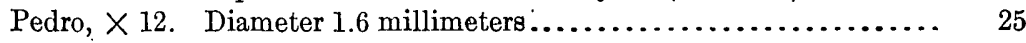

Figures 17, a-i. Group of Biloculina elongata D'Orbigny. (After Goes)....... 24

Figures 18-22. Biloculina lævis (Defránce). (After Goes)................ 25 


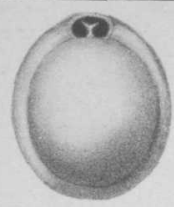

1

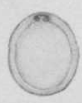

3
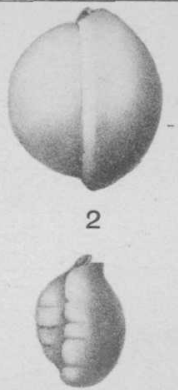

7

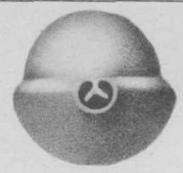

4

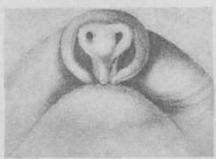

8

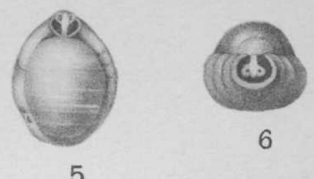

5

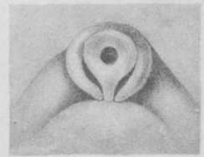

9

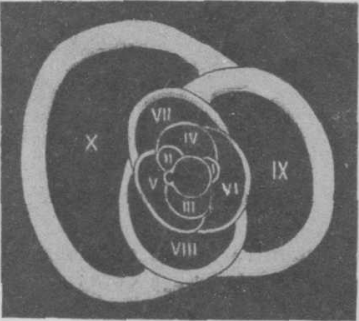

11

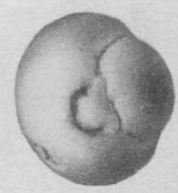

15

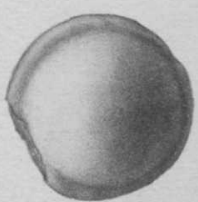

16

12

13

14

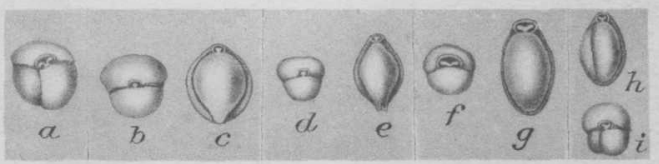

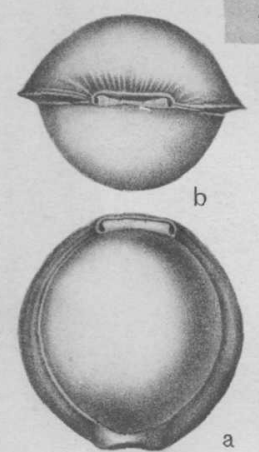

18

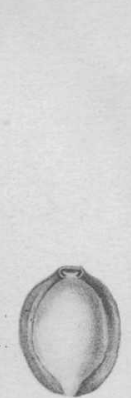

22
17

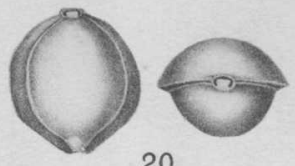

20
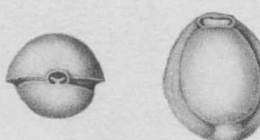

21
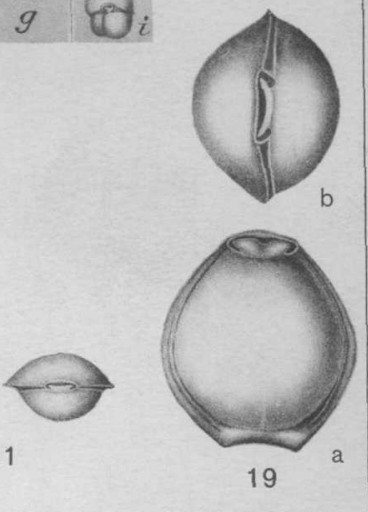

FORAMINIFERA 
PLATE II. 


\section{PLATE II.}

Figures 1, 2, 3. Biloculina depressa var. murrhina Schwager. San Pedro

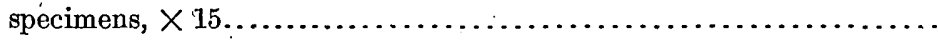

Figures 4, a-c. Biloculina depressa var. murrhina Schwager. (Brady, Challenger Rept., vol. 9, Pl. II, figs. 10, 11, a, b).....................

Frgures 5-10. Biloculina depressa D'Orbigny. (After Brady, idem, figs. $12, a, b ; 15, a, b ; 16, a, b ;$ and 17 cross section) $\ldots \ldots \ldots \ldots \ldots \ldots \ldots . . . . . . . .23$

Frgures 11, a, b. Biloculina elongata D'Orbigny. (Idem, figs. 9, a, b') ..... 24

Figures 12, 13. Biloculina bulloides D'Orbigny. (Idem, figs. 5, a, b, and 6).

These forms show pronounced prolongation of distal end............ . 23

Figure 14. Cross section of figure 13. (After Brady, idem, fig. 6) ......... 23

.98 


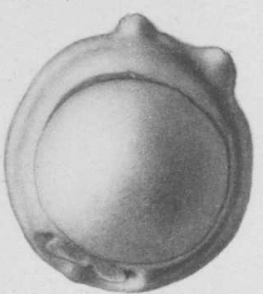

1
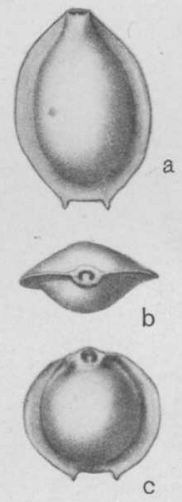

4
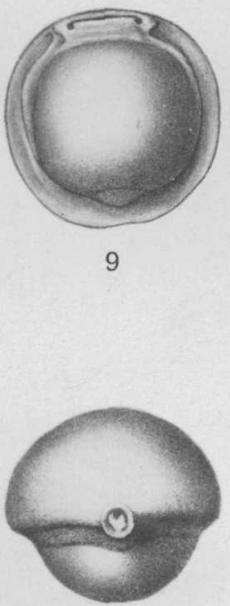

13
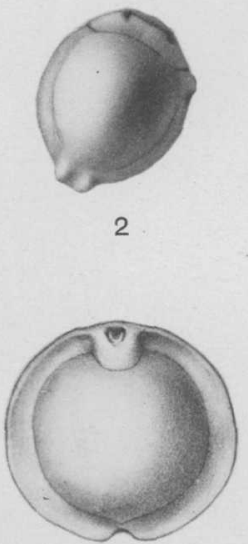

5

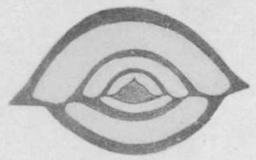

8

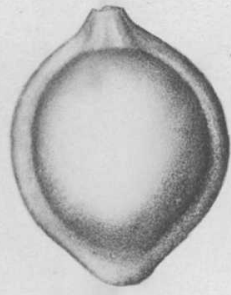

12

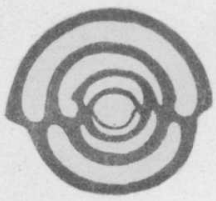

14
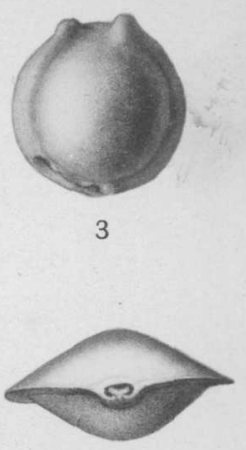

6
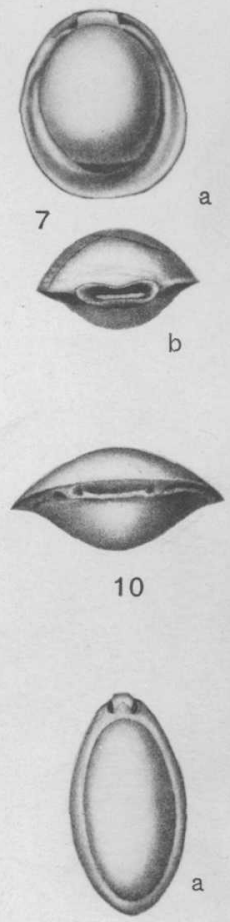

11

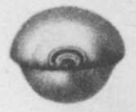

b

FORAMINIFERA 



\section{PLATE III.}

Figures 1-3. Biloculina ringens (Lamarck). (Challenger Rept., vol. 9, ' Pl.

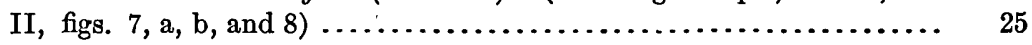

Figures 4, a, b; 5. Miliolina bicornis (Walker and Jacob). (Idem, Pl. VI,

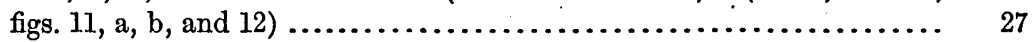

Figures 6, a, b; 7, a, b. Biloculina lævis (Defrance). (Idem, Pl. II, figs. 13,

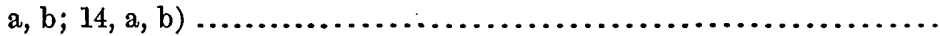

Figures 8, a, b, c. Miliolina linnæana (D'Orbigny). (Idem, Pl. VI, figs. 18,

19,20 .) End views showing apertural tooth and cross section.........

Figures 9, a, b, c. Miliolina linnæana (D'Orbigny). (Idem, P1. VI, figs.

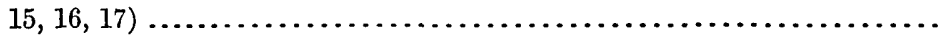

Pago. 

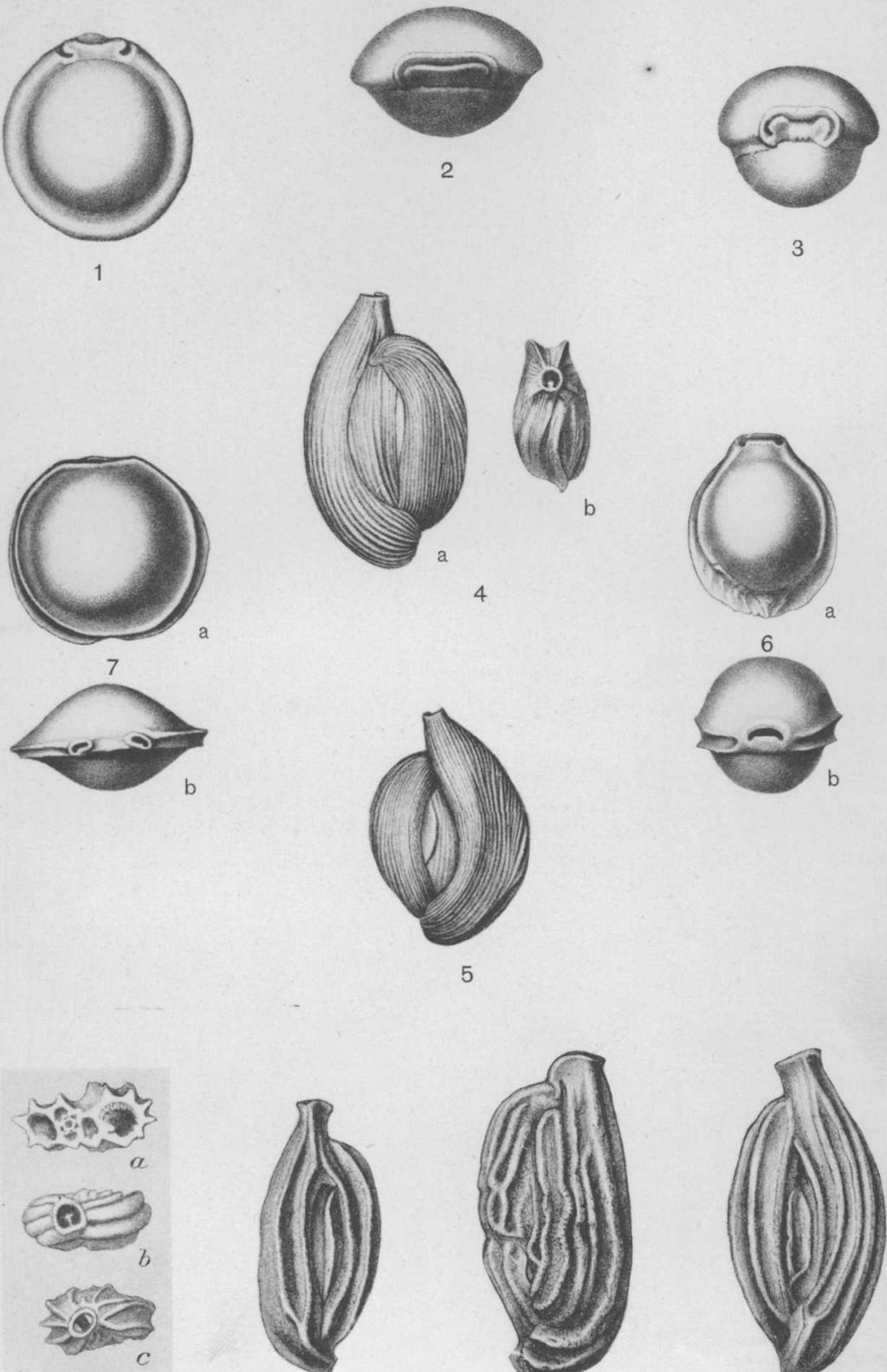

8

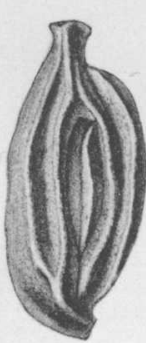

9a

5

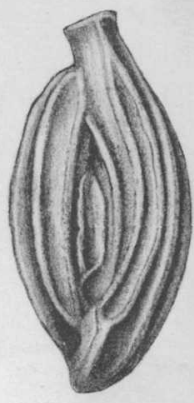

9c 


\section{PLA'TE IV.}




\section{PLATE IV.}

Figure 1. Biloculina bulloides D'Orbigny. San Pedro specimen, $\times 9 \ldots \ldots$.

Figures 2, a, b. Miliolina auberiana (D'Orbigny). From photographs of

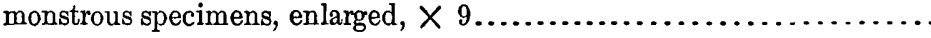

Figures 3, a-f. Group of Miliolina triangularis (D'Orbigny), variety of $M$. seminulum (Linnæus). From photographs of San Pedro forms, $\times 9 \ldots \ldots$

Figure 4. Miliolina bicornis (Walker and Jacob). (After Williamson)..........

Frgure 5. Miliolina oblonga (Montagu), typical. (After Williamson).........

Figures 6, a, b. Miliolina oblonga (Montagu). (After Brady)............. 29

Figures 7, a, b, c. Miliolina trigonula (Lamarck). (After Williamson)...... 32

Figure 8. Cross section of Miliolina auberiana (D'Orbigny). '(After Brady)... 26

Figures 9, a, b. Miliolina seminulum (Linnæus). (After Williamson)....... 30 

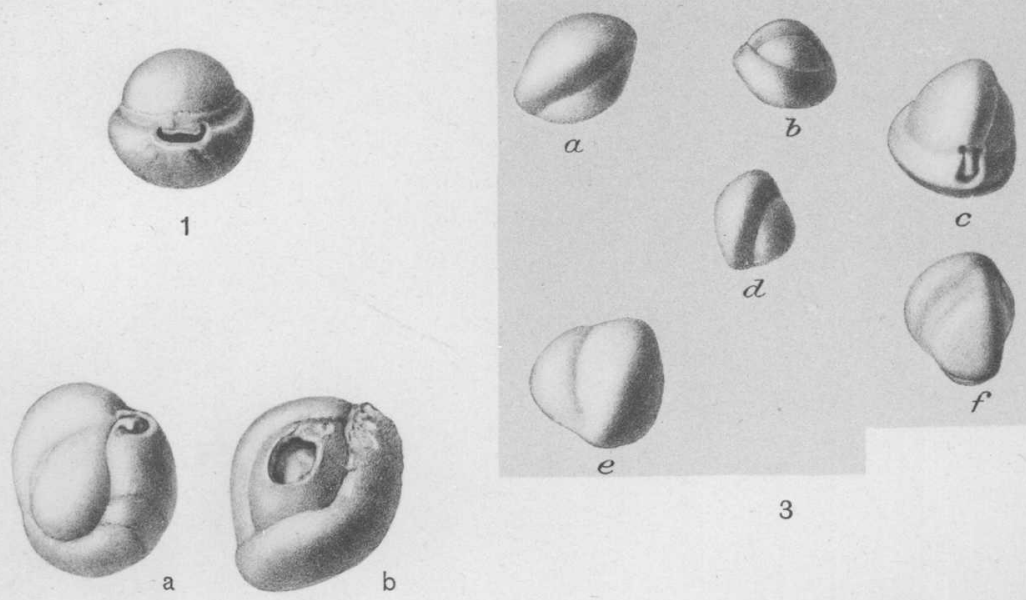

a
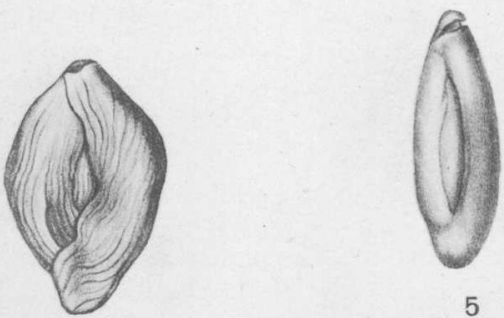

5

4
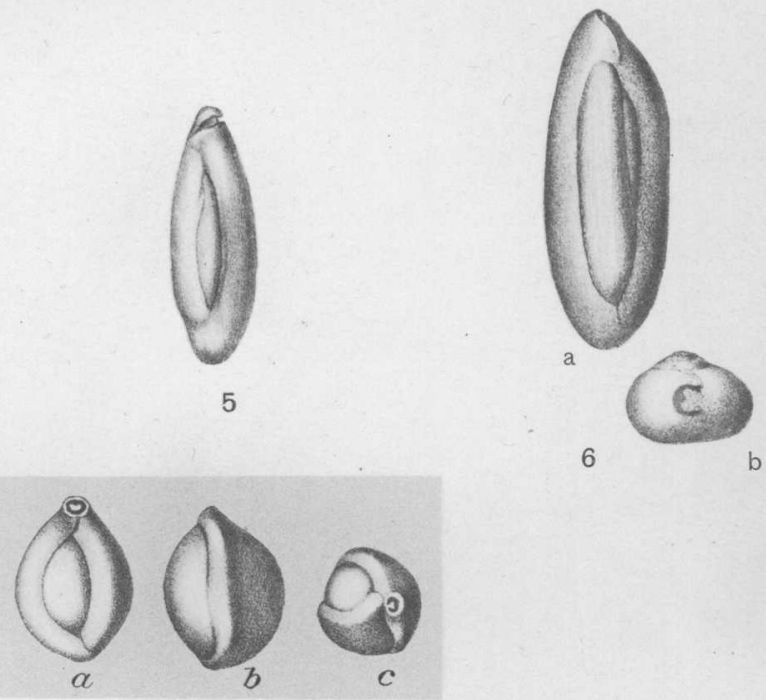

7

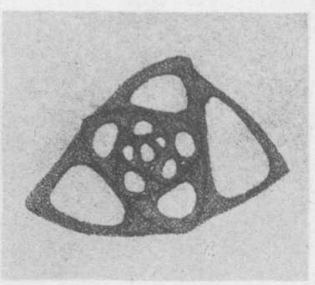

8

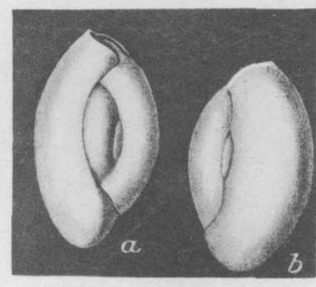

9

FORAMINIFERA 
PLATE V. 


\section{PLATE V.}

Figures 1, a-h. Miliolina bicornis (Walker and Jacob). (After Goes) Group

Page.

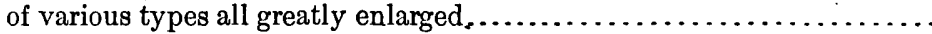

Figures 2, a, b. Miliolina pygmæa (Reuss). (After Brady).............. 30

Figures 3, a, b, c. Miliolina pulchella (D'Orbigny). (After Goes)........... 29

Figures 4, a, b. Miliolina pulchella (D'Orbigny). (After Goes)............ 29

Figures 5, a-f. Group of Miliolina tricarinata (D'Orbigny). (After Goes).... 31

104 

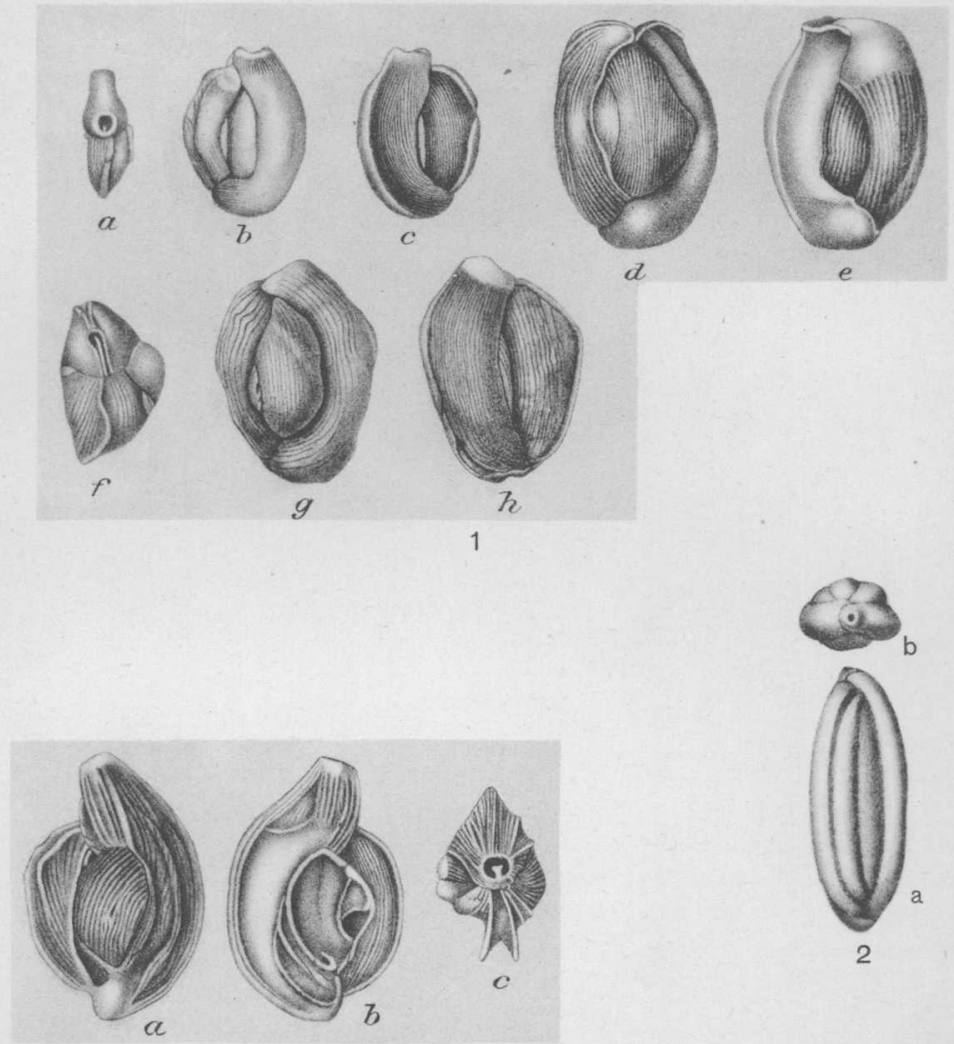

3
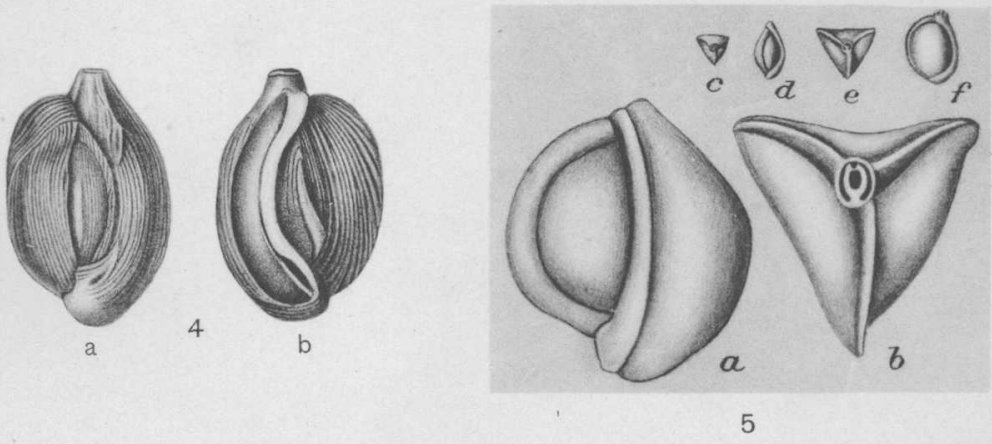

FORAMINIFERA 


\section{PLATE VI.}




\section{PLATE VI.}

Miliolina cuvieriana (D'Orbigny). (Aft

FIgURE 2. Group of Miliolina venusta (Karrer). (After Flint)................ 32

Figure 3. Group of Miliolina circularis (Bornemann). (After Flint)......... 27

FIgURE 4. Group of Miliolina trigonula (Lamarck). (After Flint)............ 32

Frgure 5. Group of Miliolina tricarinata (D'Orbigny). (After Flint).......... 31

Figures 6; a, b. Miliolina auberiana (D'Orbigny). (After Brady)............ 26

106 

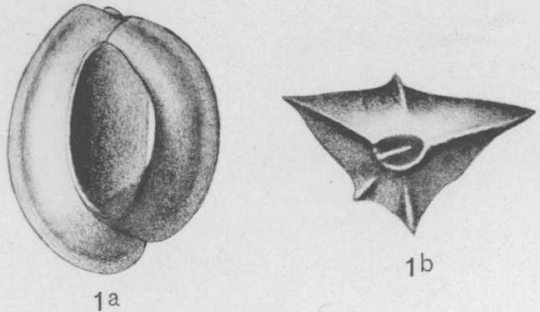

$1 b$

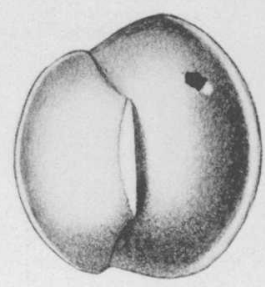

$1 c$

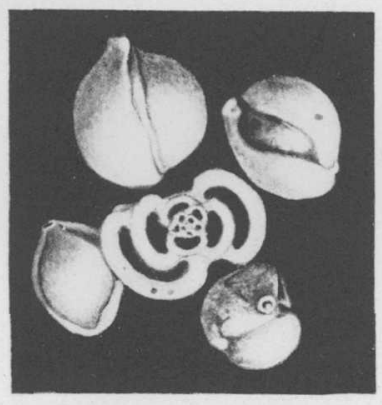

2

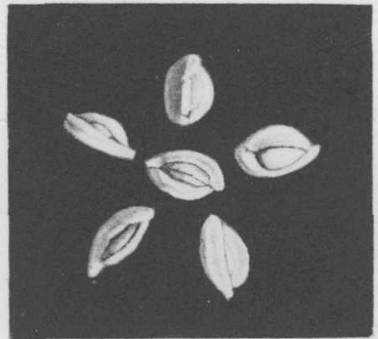

5

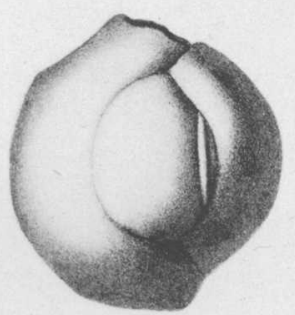

$6 a$

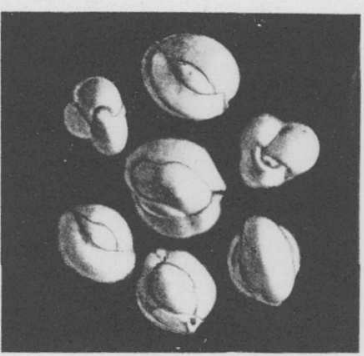

3

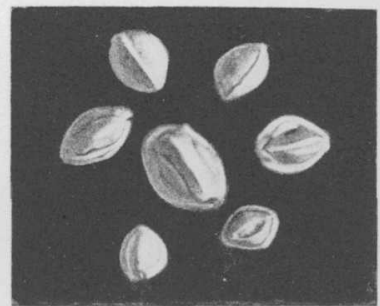

4

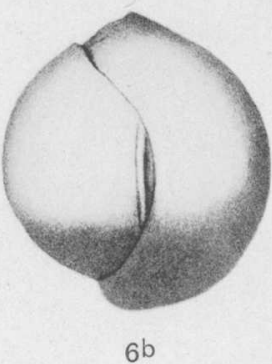

FORAMINIFERA 
PLATE VII. 


\section{PLATE VII.}

Figures 1, a-h. Group of Haplophragmium canariense (D'Orbigny). (Challen-

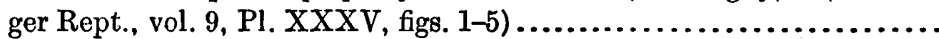

Figures 2, a, b. Trochammina trullissata Brady. (Challenger Rept., vol. 9,

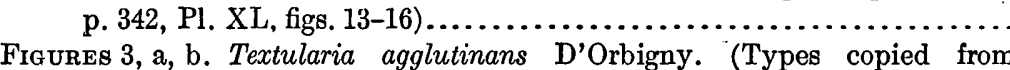

Page. Reuss, Sitzungsber. Akad. Wiss. Wien, vol. 69, 1869, Pl. I)

Figures 4, a, b. Gaudryina rugosa D'Orbigny. (Reuss, idem, vol. 18, 1855,

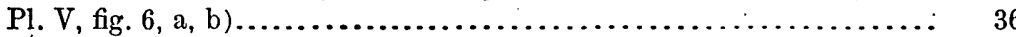

Figures 5, a, b, c. Textularia agglutinans D'Orbigny. (Goes, Kongl. Svenska

Vetenskaps-Akad. Handl., Bd. 25, No. 9, 1894. PI. VII, figs. 281-283)...

Figures 6, a, b, c; 7, a, b, c. Textularia abbreviata D'Orbigny. (Foram. foss.

Vienne, 1846, Pl. XV, figs. 7-12)............................ 

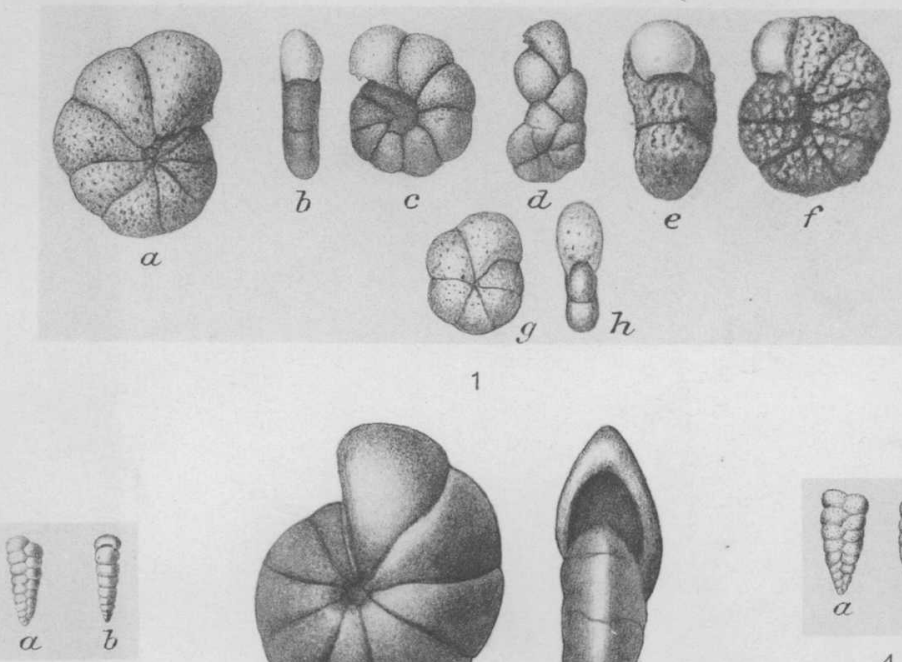

3

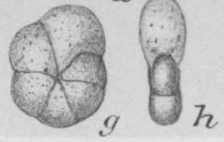

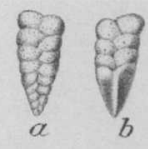

4

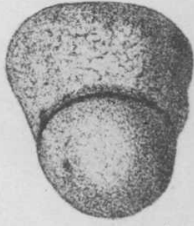

$5 c$

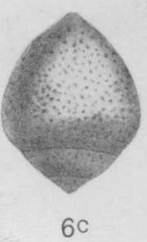

$6 b$

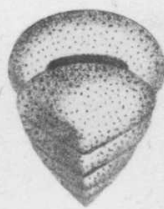

$7 b$
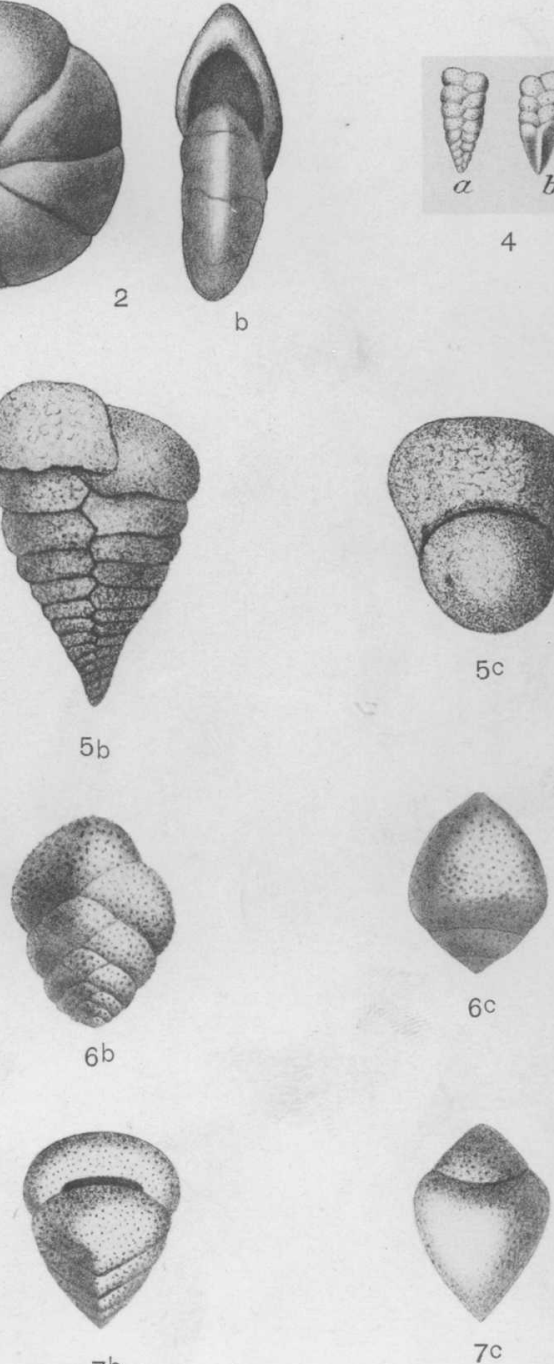

FORAMINIFERA 
PLATE VIII. 


\section{PLATE VIII.}

Frgures 1, 2, a, b, c. Textularia sagittuic Defrance. (Challenger Rept., vol.9, 1884, Pl. XIII, figs. 17, 18)................................

Page.

Figures 3-8. Gaudryina pupoides D'Orbigny. (Types copied from Goes, Kongl. Svenska Vetenskaps-Akad. Handl., Bd. 25, No. 9, Pl. VII, figs. 267, 268,

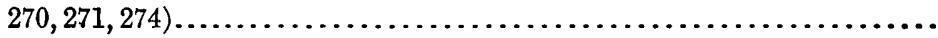
Figures 9, a-f. Sigmoilina tenuis (Czjzek). (After Brady).................

110 

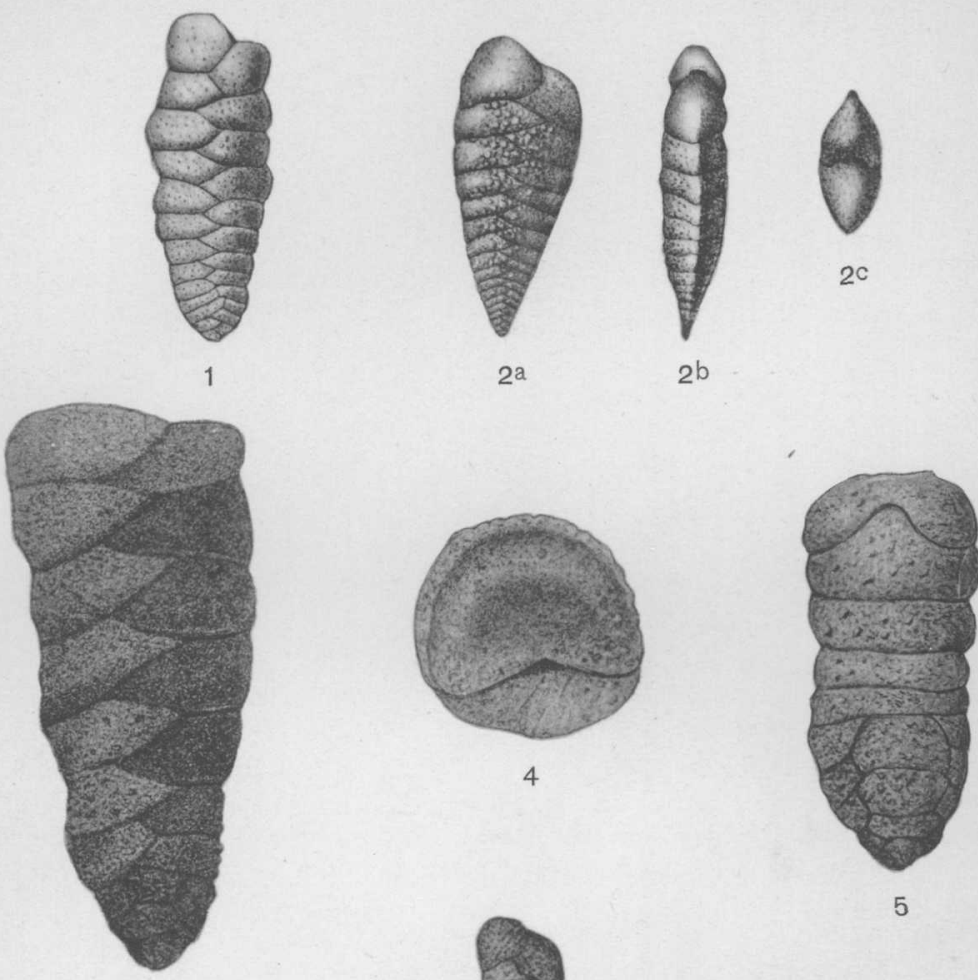

5

3
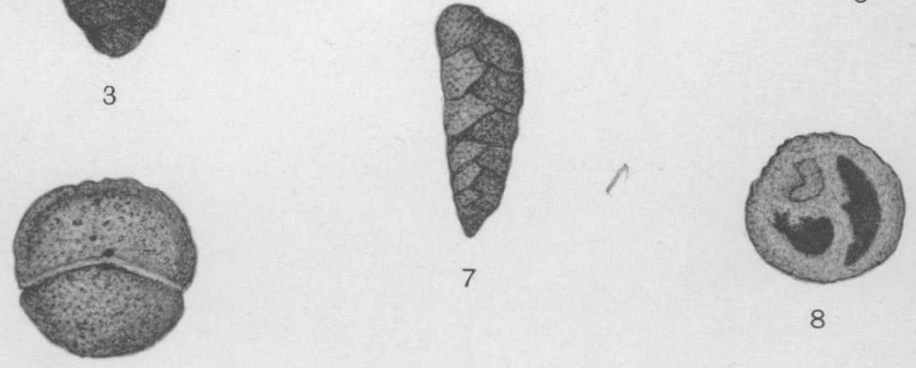

6
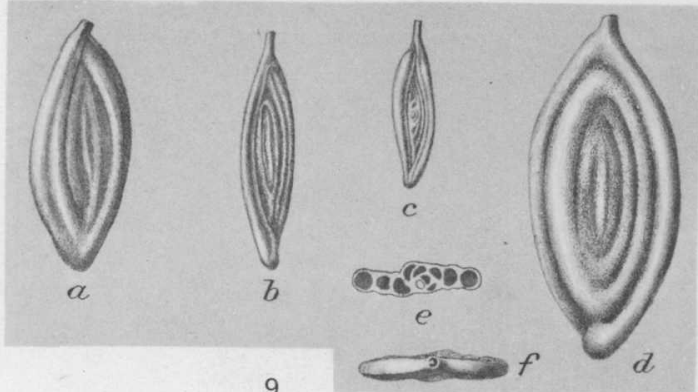

FORAMINIFERA 


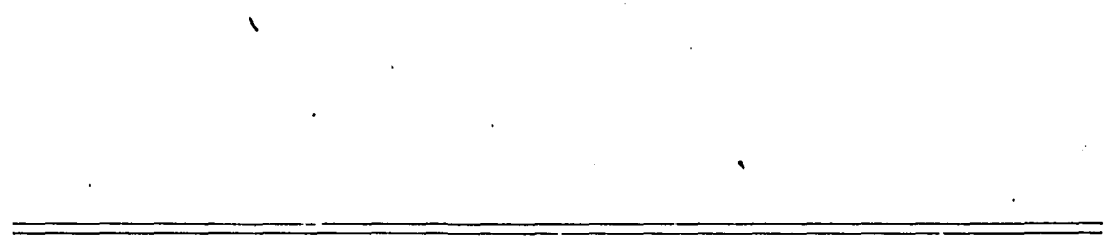

\section{PLATE IX.}




\section{PLATE IX.}

Figures 1, a-e. Bulimina pyrula D'Orbigny. (Group of typical forms, after Brady)

Page.

Figure 2. Bulimina contraria (Reuss). After a photograph of original San

Pedro specimen, $\times 15$. The diameter of our specimens varies from 0.27 to 0.3 millimeter.

Figures 3, a, b. Bulimina convoluta Williamson. (After Brady)............. 37

Figures 4, a, b. Bulimina pyrula D'Orbigny. (Copied from D'Orbigny's original figures, Foram. foss. Vienne, Pl. XI, figs. 9. 10)............ 39

Figures 5, a, b. Bulimina pupoides D'Orbigny=B. ovata D'Orbigny. (Copied from D'Orbigny's original types, Foram. foss. Vienne, Pl. XI, figs. 13, 14)..

6, a, b. Bulimina ovata D'Orbigny, typical form. (After Brady).... 38

Figures 7, a-d. Bulimina subteres Brady. (After Brady's type specimens)... 39

Figures 8, a-c. Bulimina elegantissima D'Orbigny. (After Brady).......... 38 

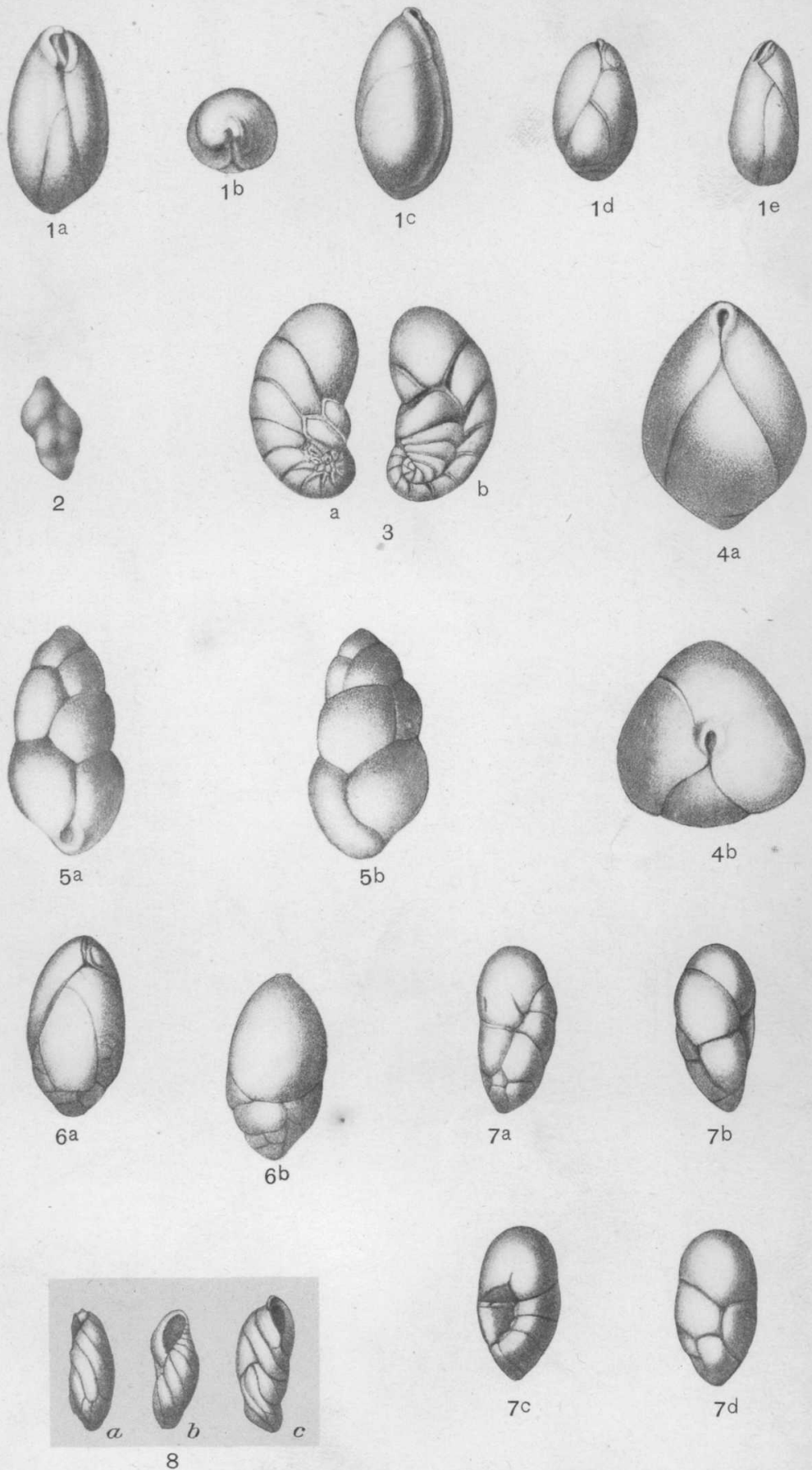


\section{PLATE X.}




\section{PLATE X.}

Figures 1, a; 2, 3, 4, 5. Bolivina punctata D'Orbigny. (Group of type forms copied from Goes, Kongl Svenska Vetenskaps-Akad. Handl., Bd. 25,

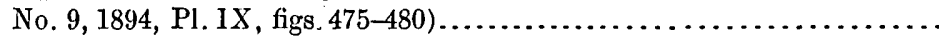

Fraures 6, a, b, c. Bolivina nobilis Hantken. (After Brady; Challenger Rept.). Figures 7, a, b; 8, 9. Bolivina beyrichi var. alata Seguenza. (After Brady)... Figure 10. Bolivina beyrichi Reuss. (After Brady, Challenger Rept.)........ Figures 11, a, b; 12, 13. Bolivina robusta Brady. (Types from Brady).......

Page. 1.14 

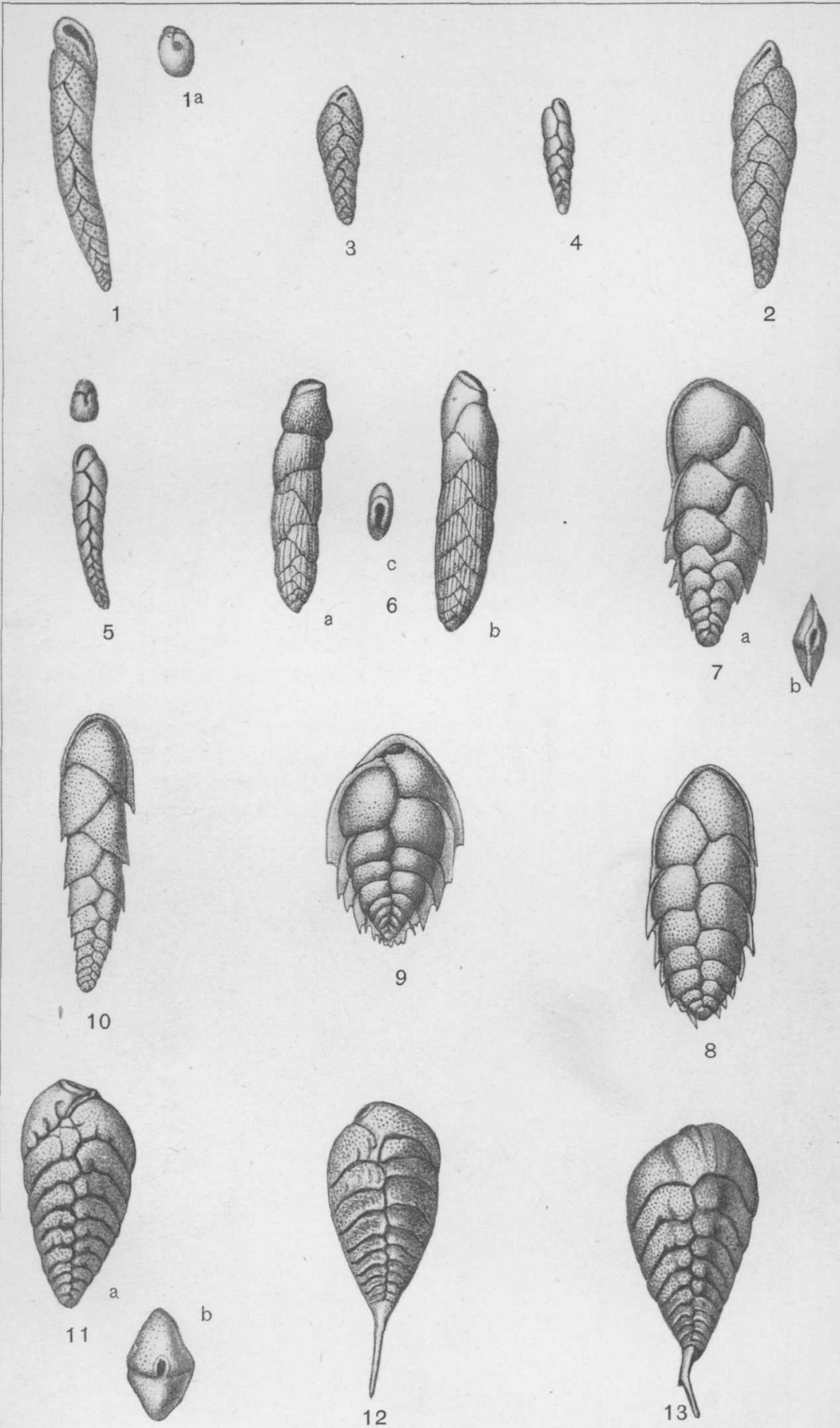

FORAMINIFERA 
PLATE XI. 


\section{PLATE XI.}

Figures 1-5. Bulimina subteres Brady. (Goes, Kongl. Svenska Vetenskaps-

Page.

Akad. Handl., Bd. 25, No. 9, 1894, Pl. IX, figs. 449-453)........... 39

Frgures 6, a, b. Bolivina textilarioides Reuss. (Copied from Reuss's type,

Sitzungsber. Akad. Wiss. Wien, vol. 46, 1862, Pl. X, figs. 1a, b)....... 42

Figures 7, a, b; 8, a, b; 9. Bolivina dilatata Reuss. (Goes, Kongl. Svenska Vetenskaps-Akad. Handl., Bd. 25, No. 9, 1894, Pl. IX, figs. 482-486)... 40

116 


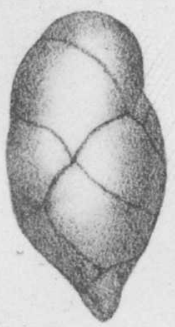

1

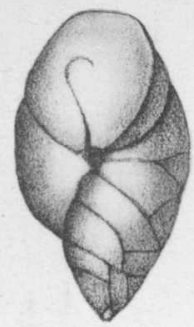

4

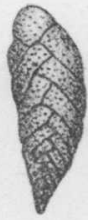

9

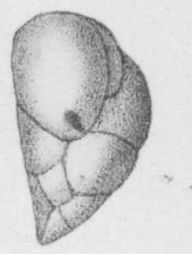

3
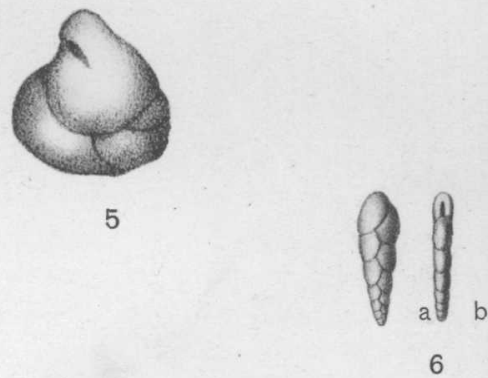

5

6
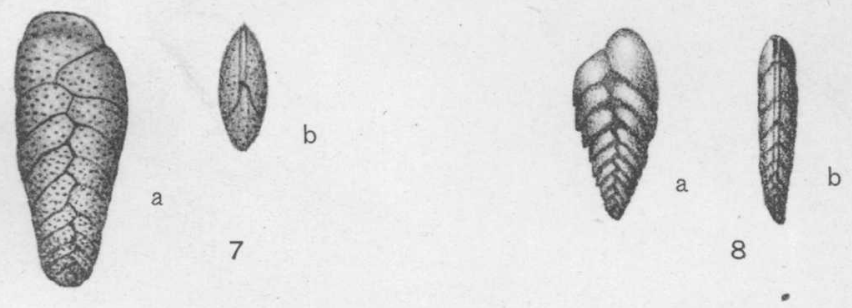


\section{PLATE XII.}




\section{PLATE XII.}

Page.

Figures 1, a-c. Cassidulina calabra (Seguenza). (After Brady)............ 42

Figures 2, a, b. Cassidulina subglobosa Brady. (Brady, Challenger Rept.).. 44

Figures 3, a, b. Cassidulina lævigata D'Orbigny. (Brady, Challenger Rept.).. 43

Figure 4. Group of San Pedro types of Cassidulina subglobosa Brady........ 44

Figures 5, a-c. Cassidulina lævigata D'Orbigny. (After Brady)............ 43

Figures 6 a-f. Group of types of Cassidulina crassa D'Orbigny. (Brady, Chal-

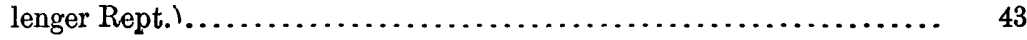

118 


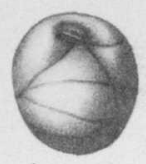

$1 \mathrm{a}$

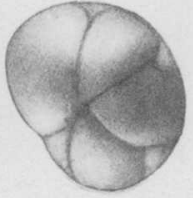

$2^{a}$

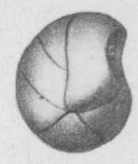

$1 \mathrm{~b}$

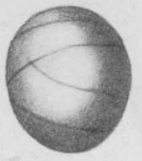

$1 \mathrm{c}$

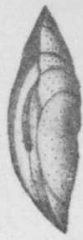

$3 b$

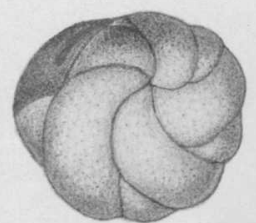

$3 a$

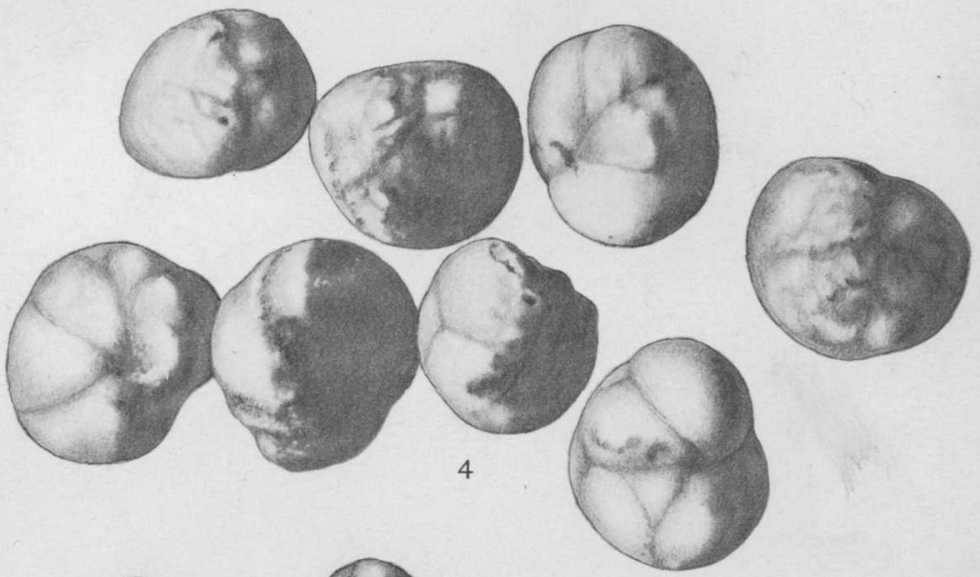

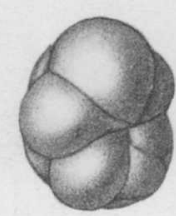

a

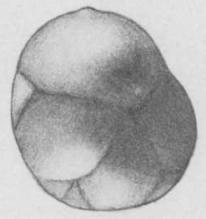

$2 b$
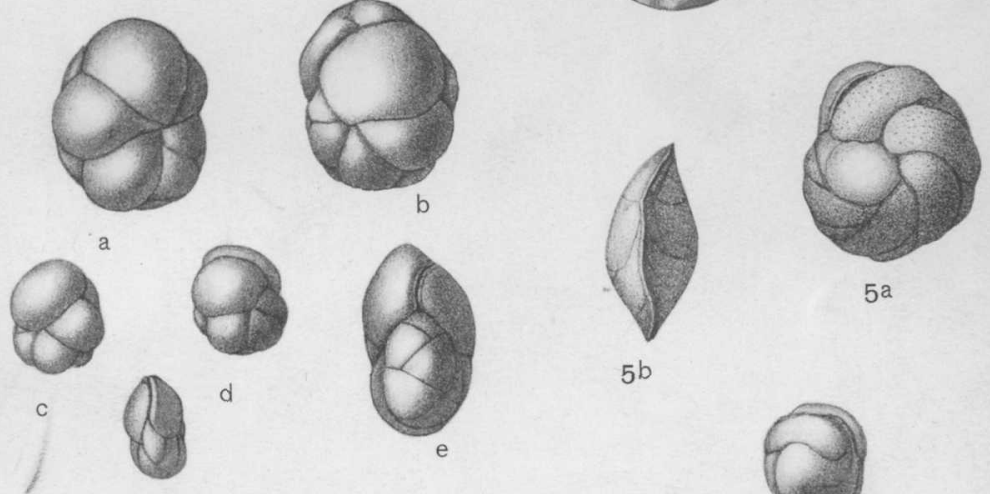

b
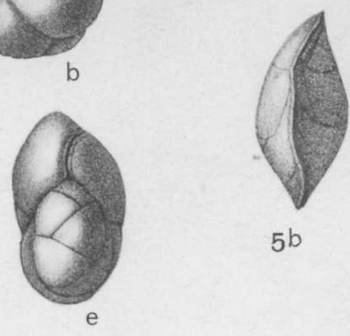

$5 b$

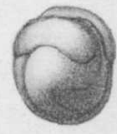

$5 c$

FORAMINIFERA 


\section{PLATE XIII.}




\section{PீLATE XIII.}

Figures 1, a, b. Lagena dentaliformis n. sp. Two specimens from San Pedro nearly complete, $\times 11_{\frac{1}{2}}$. Length about 2 millimeters.................

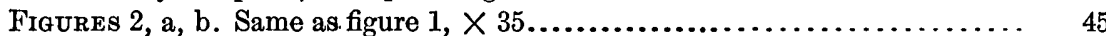

Figure 3. Lagena gracillima (Seguenza). From a photograph, $\times 16 \ldots \ldots . .47$

Figures 4, a, b. Lagena elongata (Ehrenberg). From photographs of San Pedro types, $X$ about 10 . The ends of both of our specimens are broken off.................................................... 46

Figures 5, a, b. Lagena lævis (Montagu). San Pedro types, $\times 15 \ldots . . . . . . .448$

Frgures 6, a-c; 7, a-c; 8, a-k. Lagena lavis (Montagu). San Pedro Pliocene specimens from original photographs..................... 48

Fraures 9, a, b, c. Lagena globosa (Montagu). (Reuss, Sitzungsber. Akad. Wiss. Wien, vol. 46, 1862, Pl. I, figs. 1-3) ................... 46

Figures 10, 11, a, b. Lagena lævis (Montagu). (Reuss, same plate as figure 9). 48

Frgure 12. Lagena sesquistriata $\mathrm{n}$. sp., $\times 36$. This specimen approaches Lagena acuticosta Reuss but has fewer costæ and more apiculate oral end. The specimen was photographed with the aperture tipping downward, which gives the specimen a somewhat shorter appearance than it actu-

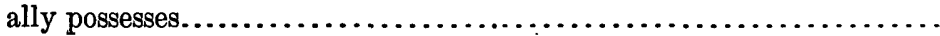

Frgure 13. Lagena sesquistriata n. sp., $\times 36$. This is a typical form and approaches Lagena gracilis, but it is broader at the base and has fewer costæ.

The length of both of our types of Lagena sesquistriata $n$. sp. is about 0.5 millimeter.

Figures 14, a, b. Smaller aspects of the same types as figures 12 and $13 . \ldots$. 

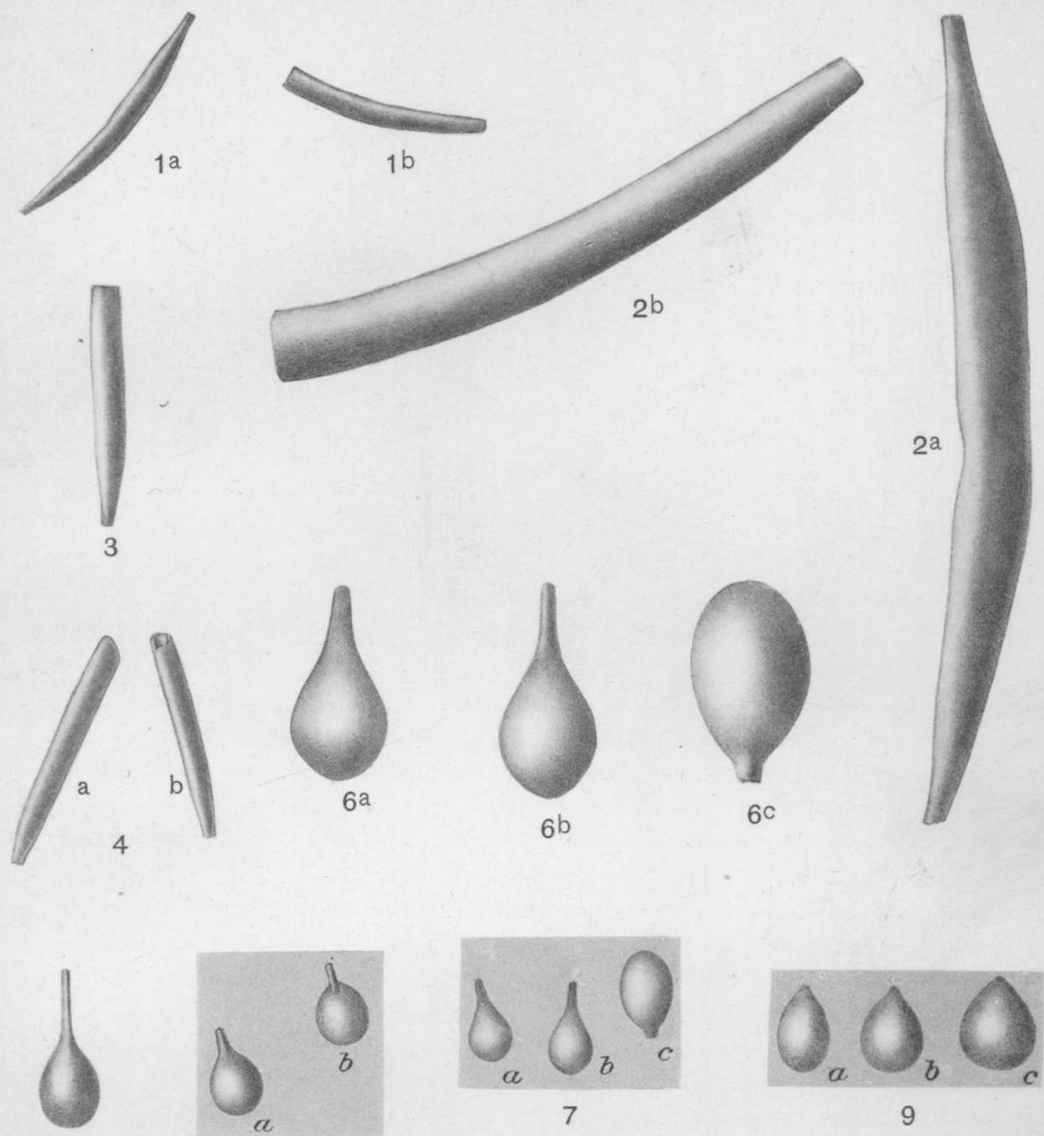

10
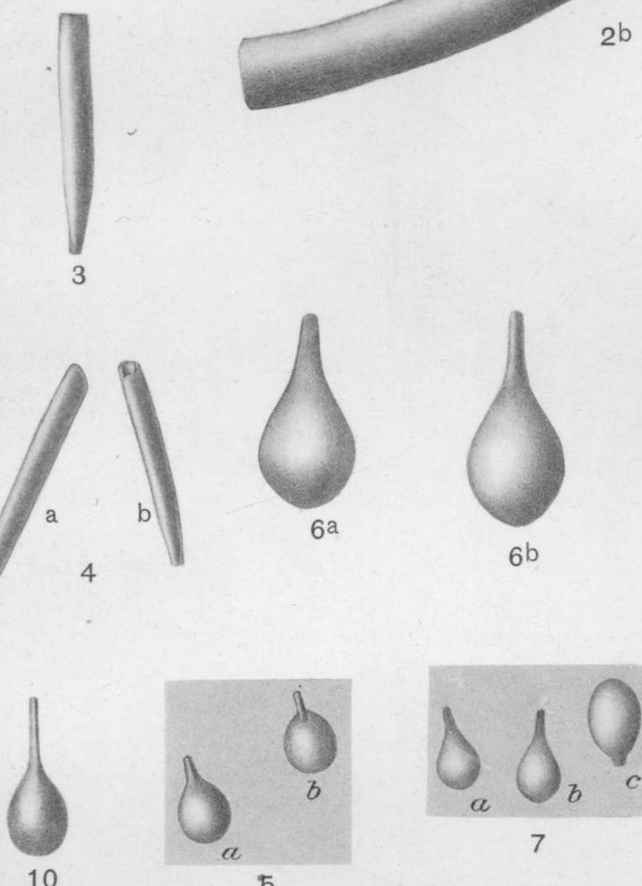

5
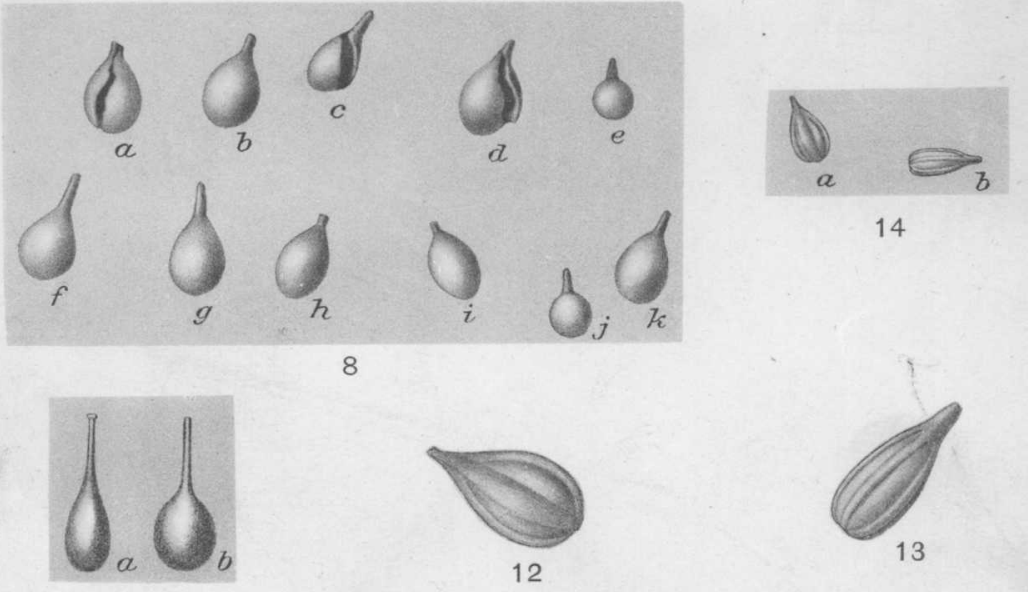

14

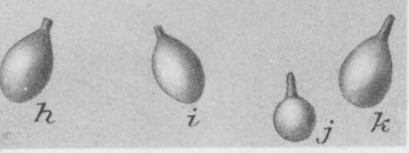

8
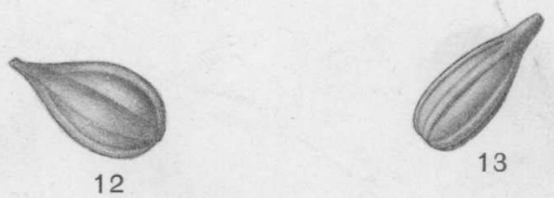
PLATE XIV. 


\section{PLATE XIV.}

Figures 1-4. Lagena semistriata Williamson. (After Reuss, Sitzungsber. .Akad. Wiss. Wien, vol. 46, 1862, Pl. II, figs. 2, 3)...............

Figure 5. Lagena semistriata Williamson. (After Williamson's original type, Recent Foram. Great Britain, 1858, PI. I, fig. 9)....................

Fraure 6. Lagena striata D'Orbigny. (After Williamson, same plate as figure 5)

Figure 7. Lagena gracilis Williamson. (After Reuss, Sitzungsber. Akad.

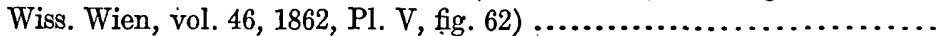

Frgures 8, a, b. Lagena gracilis Williamson. (After Williamson's original drawings, Recent Foram. Great Britain, 1858, Pl. I, figs. 12, 13)......

Frgures 9, a-c. Lagena sulcata (Walker and Jacob). (Jones, Paleont. Soc., 1866, Pl. I, figs. 40, 41, 43.) Three specimens....................

Figures 10, 11, 12, a, b. Lagena sulcata (Walker and Jacob). (Jones, idem.,

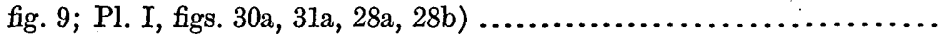

Figures 13, 14, 15. Lagena striatopunctata Parker and Jones. (Philos. Trans.,

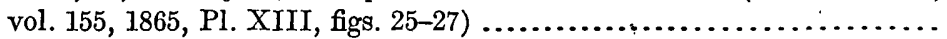

Figure 16. Lagena melo D'Orbigny. (After Jones, Paleont. Soc., 1866, Pl. I, fig. 35)

Figure 17. Lagena melo D'Orbigny. (After Parker and Jones, Philos. Trans., vol. 155,1865 , Pl. XIII, fig. 33$)$............................

Figures 18, a-c. Lagena marginata (Walker and Boys). (After Williamson, Recent Foram. Great Britain, 1858, Pl. I, figs. 19, 20, 21) ...........

Fraures 19, a, b. Lagena quadrata (Williamson). (Idem, figs. 27, 28) ........

Figure 20. Lagena quadrata (Williamson). (After Reuss, Sitzungsber. Akad.

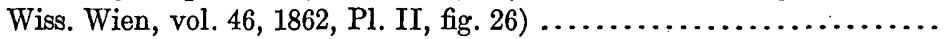

Figures 21, a, b. Lagena marginata (Walker and Boys). (After Reuss, idem,

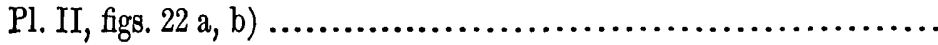

Figures 22, a, b. Lagena marginata (Walker and Boys). (Copied from Reuss, same plate as fig. 21 . Note that fig. 21 shows entosolenian tube) ......

Figures 23, 24. Lagena lævis (Montagu) = Lagena vulgaris Williamson. (After Williamson, Recent Foram. Great Britain, 1858, Pl. I, figs. 5, 5a) ......

Figures 25, 26. Lagena lagenoides (Williamson). (Idem, figs. 25, 26) ........

Figure 27. Lagena squamosa (Montagu), typical form. (After Williamson,

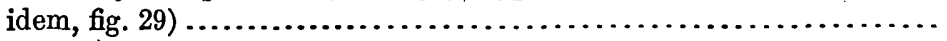

Fraure 28. Lagena acuticosta Reuss. (Sitzungsber. Akad. Wiss. Wien, vol.

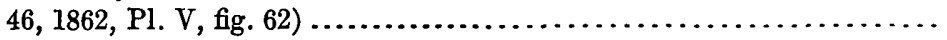

Page. 

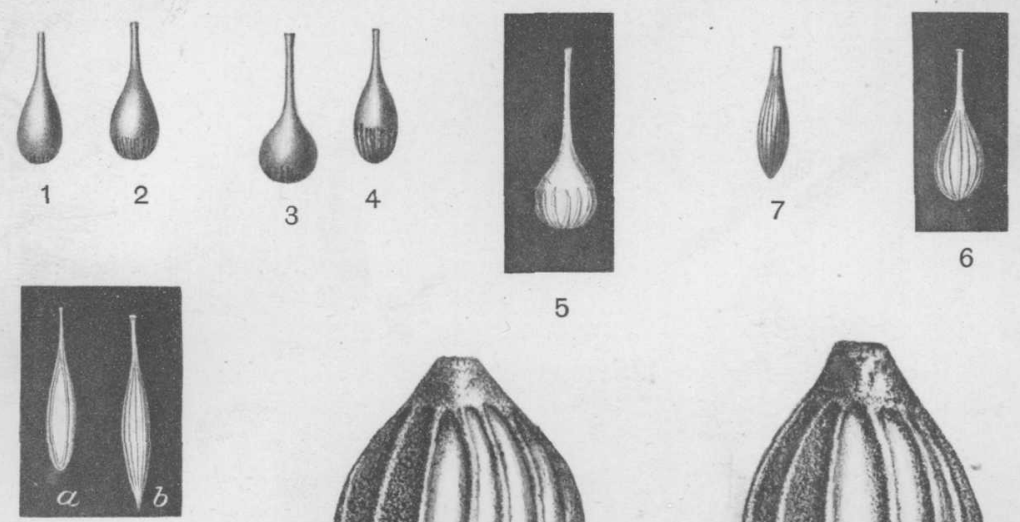

8

5
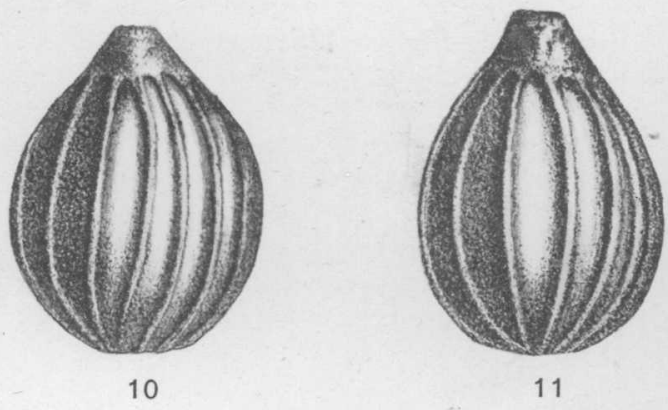

$\mathbf{O}_{a} \mathrm{O}_{b}$

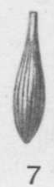

11

9
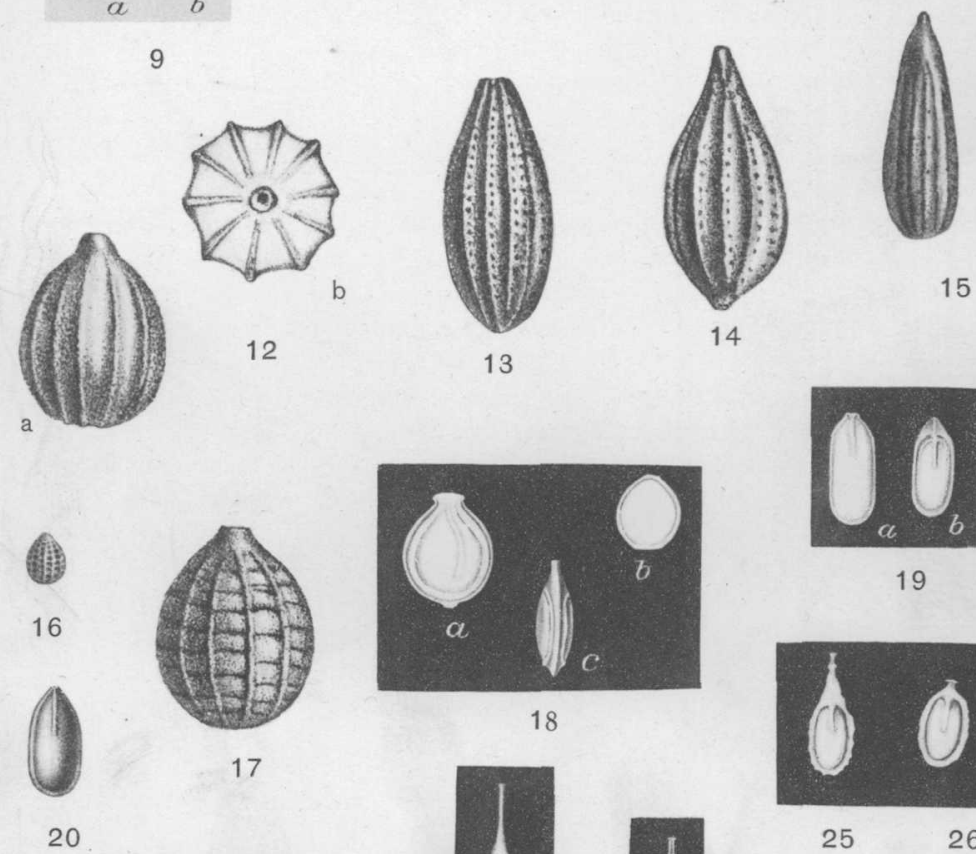

18
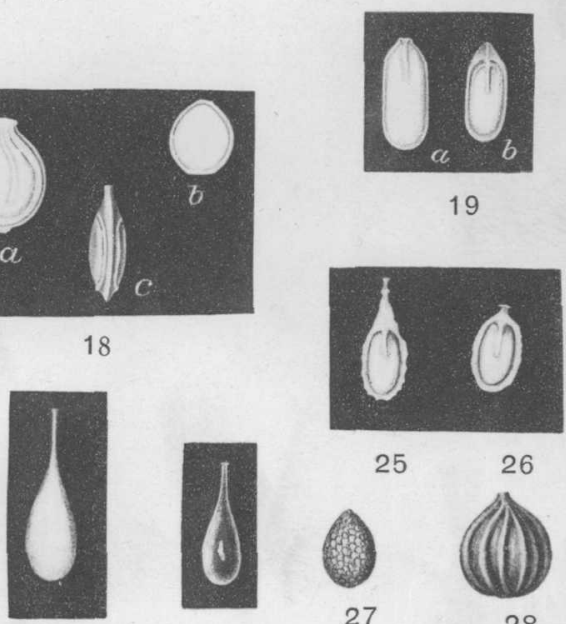

23

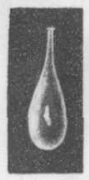

24

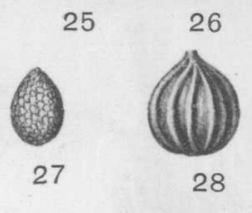

FORAMINIFERA 
PLATE XV. 


\section{PLATE XV.}

Figures 1, a-d. Nodosaria obliqua (Linnæus). (Goes, Kongl. Svenska Vetenskaps-Akad. Handl., Bd. 25, No. 9, 1894, Pl. XIII, figs. 691-692)....... 57

Figures 2, a, b. Nodosaria soluta (Reuss). (After Goes, idem, No. 1)........ 59

Figures 3, a, b. Nodosaria calomorpha Reuss. San Pedro types, $\times 15 \ldots \ldots . \quad 53$

Figure 4. Nodosaria sp. An aberrant San Pedro type approaching Bigenerina, with basal segment almost divided, $\times$ about 10. $\quad$ (See $N$. pauperata)... 58

Figures 5, a-d. Group of San Pedro broken and fragmentary forms of Nodosaria consobrina (D'Orbigny), a very common nodosarian, $\times 10 \ldots \ldots$.

Page. 7 

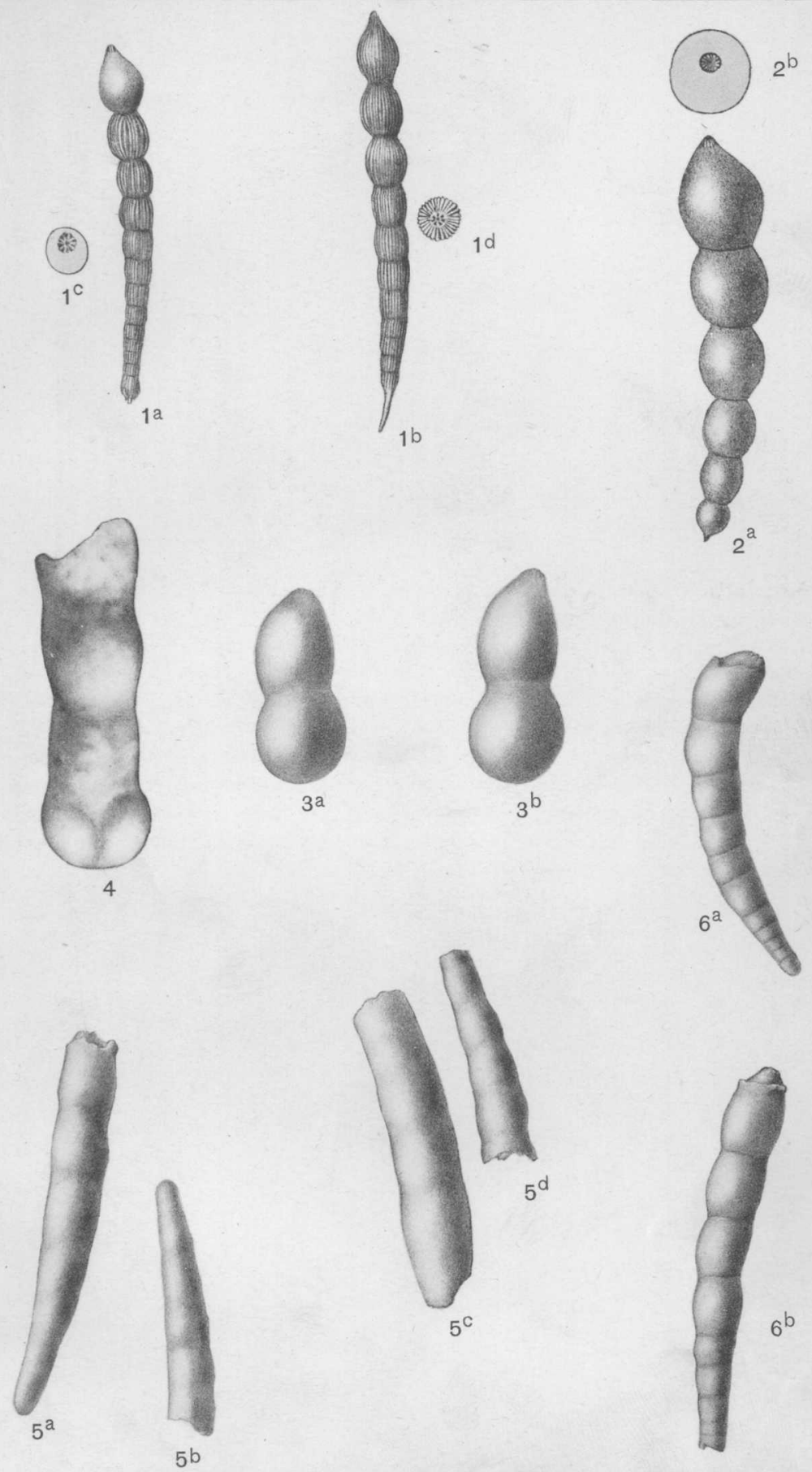

FORAMINIFERA 
$=$

PLATE XVI. 


\section{PLATE XVI.}

Figure 1. Nodosaria decepta n. sp. San Pedro form, $\times 10 \ldots \ldots \ldots \ldots \ldots \ldots . . .65$

Figures 2, a-f. Group of Nodosaria pauperata (D'Orbigny). From photographs of San Pedro specimens, $\times 7 \ldots \ldots \ldots \ldots \ldots \ldots \ldots \ldots \ldots \ldots \ldots . . \ldots 7$

Figures 3, a-c. Nodosaria seminuda Reuss. San Pedro forms, $\times 10 \ldots \ldots$

Frgure 4. Nodosaria sagrinensis n. sp. San Pedro specimen, $\times 60 \ldots \ldots \ldots . \quad 58$

Figure 5. Group of Nodosaria communis (D'Orbigny). (After Flint, Rept.

U. S. Nat. Mus. for 1897, p. 310, pl. 56, fig. 2) ............... 54

Figure 6. Group of Nodosaria consobriná var. emaciata Reuss. (After Flint).. 55

Figure 7. Group of Nodosaria soluta Reuss. (Flint, op. cit., Nos. 5, 6).... 59

Figure 8. Nodosaria communis (D'Orbigny). San Pedro specimen, $\times 8 \frac{1}{2} \ldots \quad 54$

Figure 9. Nodosaria communis (D'Orbigny). A smaller San Pedro type with fewer chambers, $\times 8 \frac{1}{2} \ldots \ldots \ldots \ldots \ldots \ldots \ldots \ldots \ldots \ldots \ldots \ldots \ldots \ldots \ldots \ldots$ 

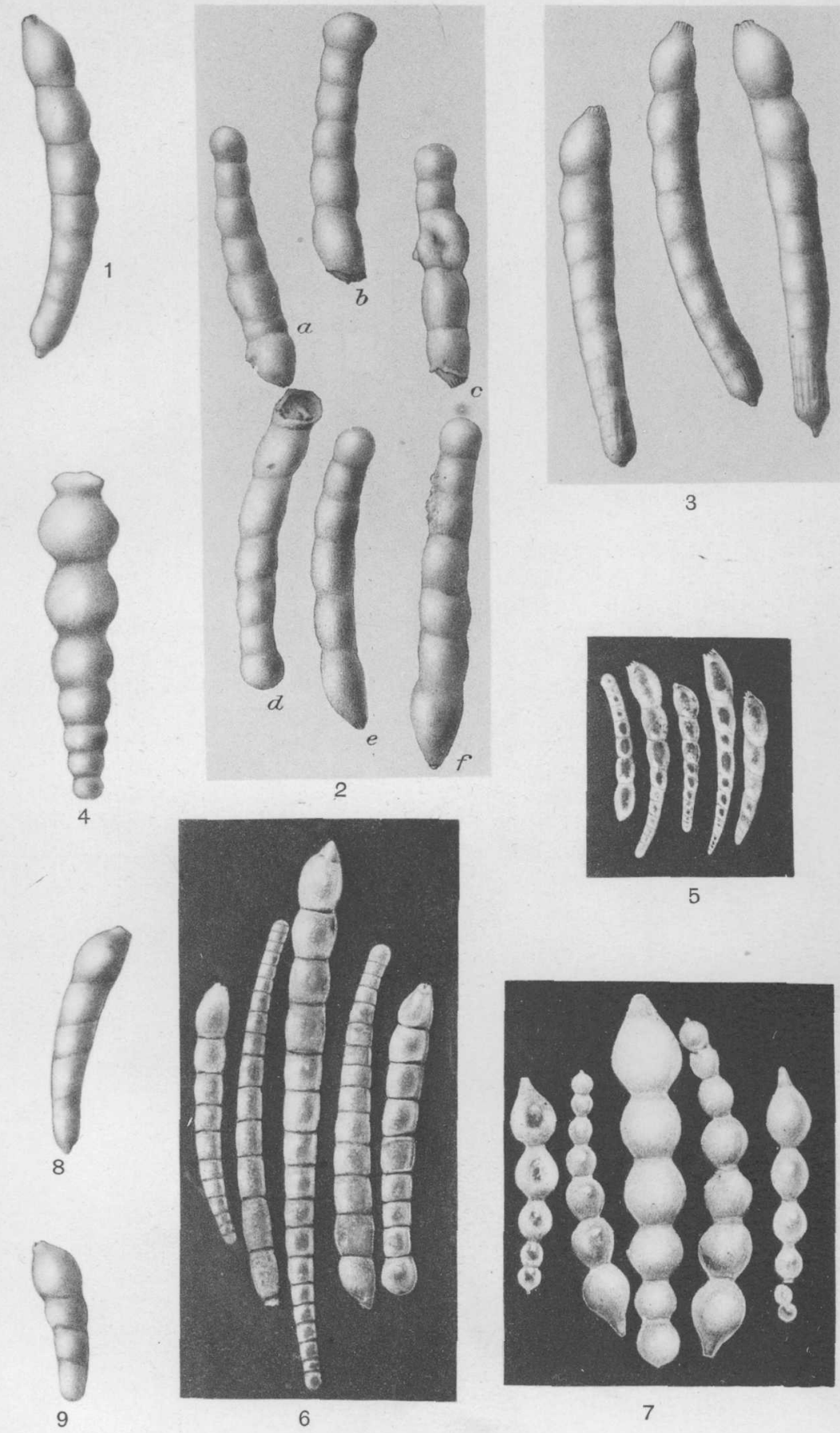

FORAMINIFERA 


\section{PLATE XVII.}




\section{PLATE XVII.}

Figures 1, a-d. Nodosaria obliqua (Linnæus). (Goes, Kongl. Svenska Vetenskaps-Akad. Handl., Bd. 25, No. 9, 1894, Pl. XII, figs. 693, 694,

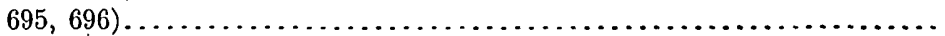

Figure 2. Group of Nodosaria vertebralis (Batsch). (After Flint, Recent Foram.: Rept. U. S. Nat. Mus. for 1897 (1899), pl. 57) ................... Figure 3. Group of Nodosaria farcimen (Soldani). (Flint, idem, No. 2, pl. 55,

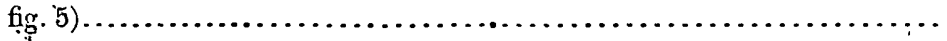




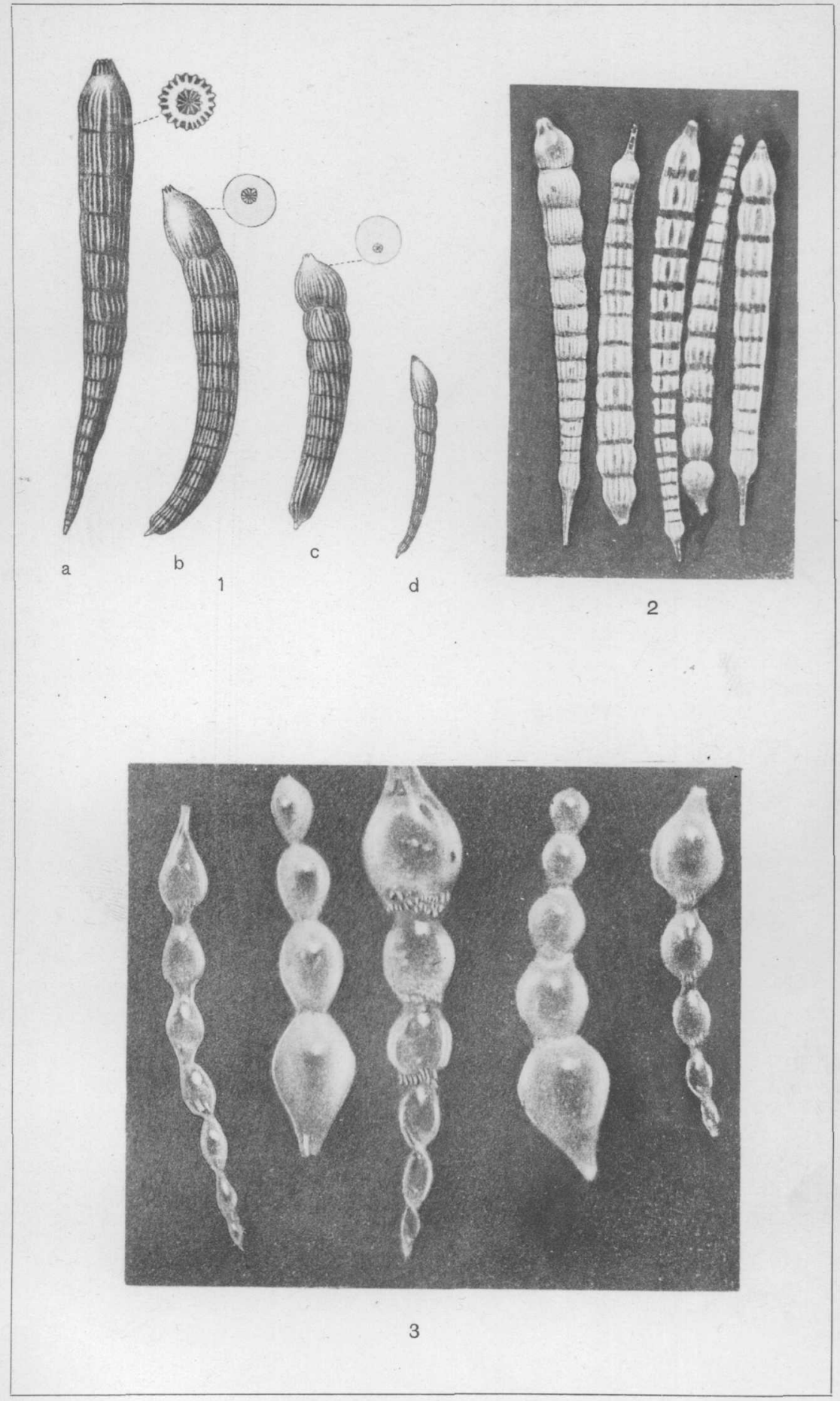

FORAMINIFERA 


\section{PLATE XVIII.}




\section{PLATE XVIII.}

Fradres 1, a-e. Group of Frondicularia inæqualis Costa from San Pedro, $\times 10$ Page.

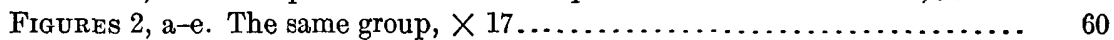

Figure 3. Frondicularia lavigata Karrer. (Type form published by Karrer, Sitzungsber. Akad. Wiss. Wien, vol. 58, 1868, Pl. IV, fig. 3) ........ 61

Frgure 4. Marginulina costata (Batsch). San Pedro form, $\times 15$. The specimen is complete and measures 1.5 millimeters in length.............

Figures 5, a, b. Vaginulina badenensis D'Orbigny. Two San Pedro forms

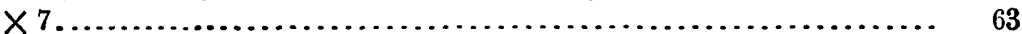

Fraures 6, 7. Vaginulina legumen (Linnæus). Two San Pedro types, $\times 10 \ldots \quad 63$

Figures 8, a-c. Vaginulina legumen var. arquata Brady. From a photograph

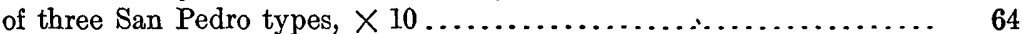

Figures 9, a, b. Vaginulina linearis (Montagu). San Pedro forms, $\times 10 \ldots .64$

Figure 10. Vaginulina obliquistriata Jones. San Pedro type, $\times 15 \ldots \ldots \ldots 66$

Figure 11. Vaginulina obliquistriata Jones. San Pedro fragment, $\times 15 \ldots \ldots 65$ 


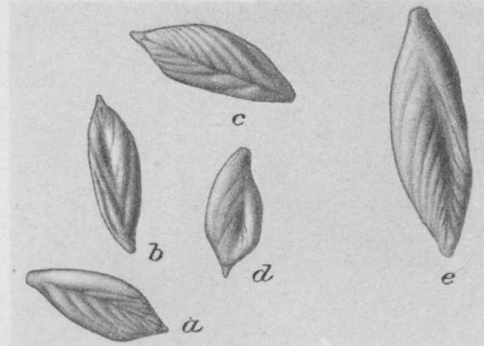

1
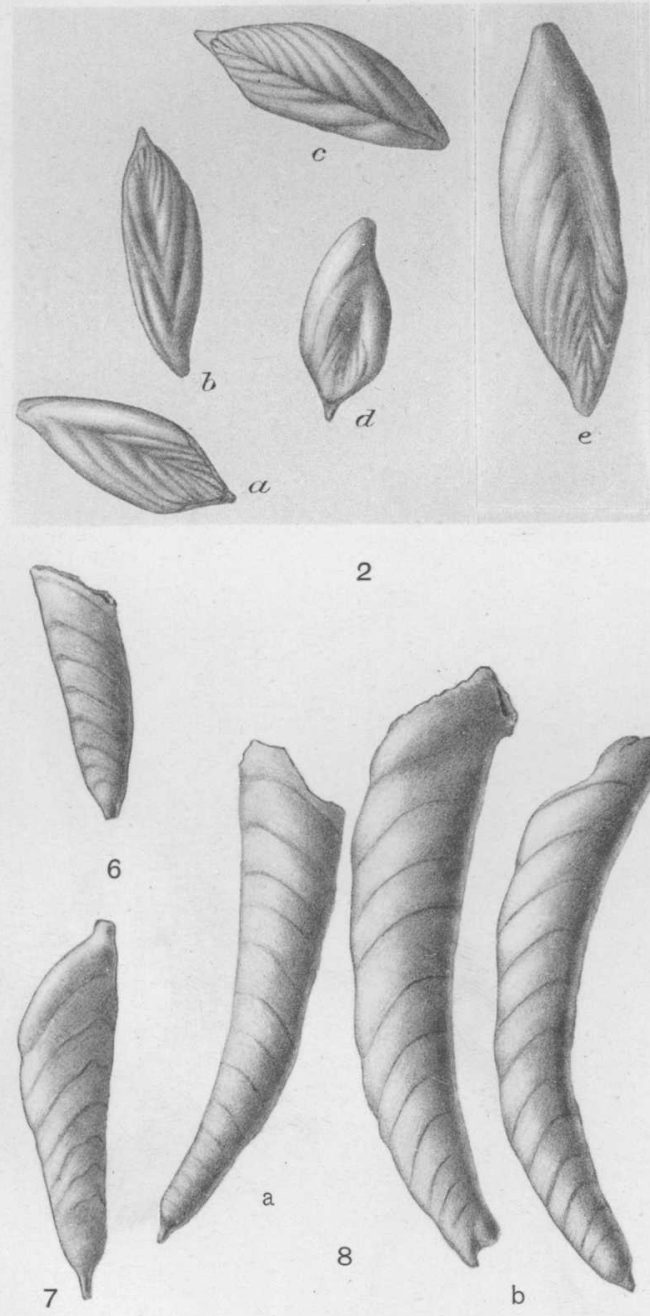

2

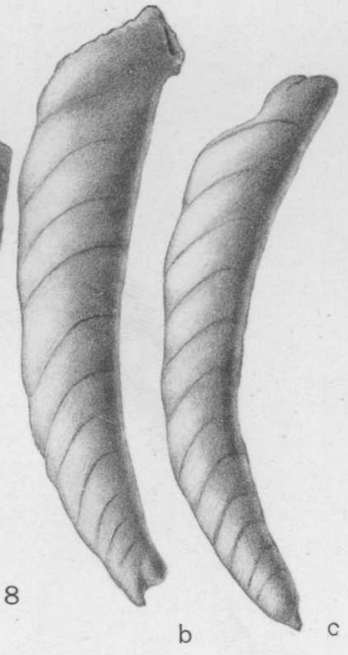

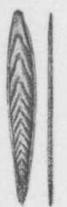

3
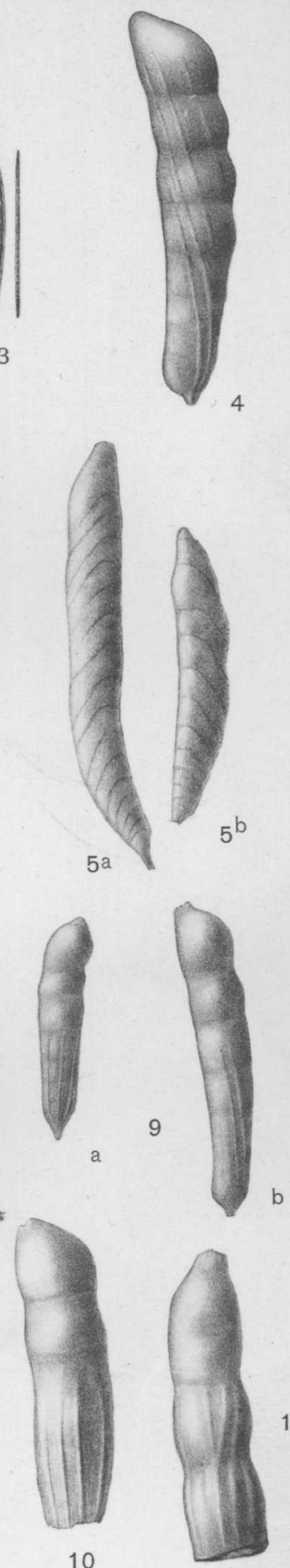

FORAMINIFERA 


\section{PLATE XIX.}




\section{PLATE XIX.}

Figures 1, a, b. Cristellaria josephina D'Orbigny. (After D'Orbigny's original drawing, Foram. foss. Vienne, 1846, Pl. III, figs. 37, 38) ........... 66

Figures 2, a, b. Two specimens of Cristellaria reniformis D'Orbigny. From

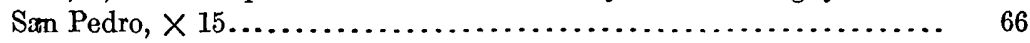

Figure 3. Cristellaria crepidula (Fichtel and Moll). San Pedro form, $\times 15 \ldots .65$

Figures 4, a-c. Cristellaria gibba D'Orbigny. (Challenger Rept., vol. 9, PI.

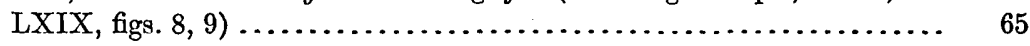

Figures 5, a, b. Cristellaria rotulata (Lamarck). (Idem, Pl. LXIX, fig. 13).. 67.

Figures 6, 7. Dimorphina tuberosa D'Orbigny. (Brady, Parker, and Jones, Trans. Linn. Soc. London, vol. 27, 1869, Pl. XLII.) Figure 6 is after D'Orbigny's original modele 60 . Figure 7 is a copy of a Crag Pliocene

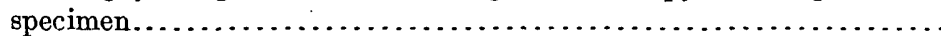

Figure 8. Polymorphina soldanii D'Orbigny. (Brady, Parker, and Jones, idem, Pl. XL, fig. 20)................................... 


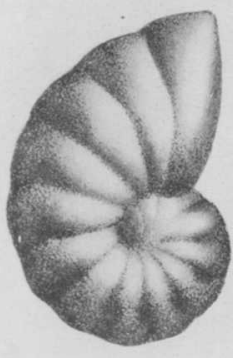

12

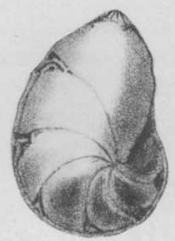

$4 a$

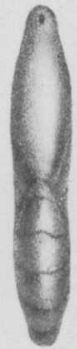

$1 \mathrm{~b}$
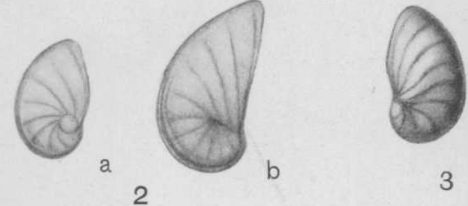

3

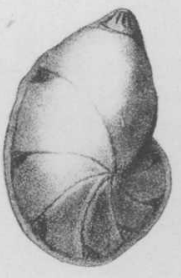

$4 c$

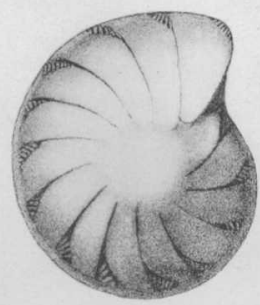

$5 a$
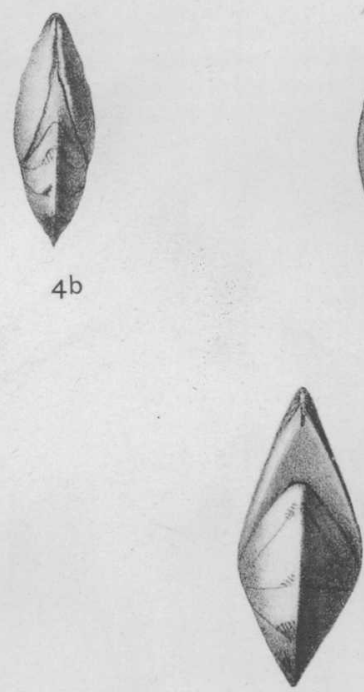

$5 b$

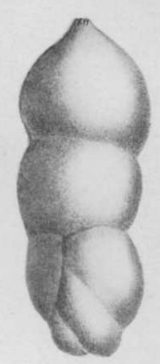

6
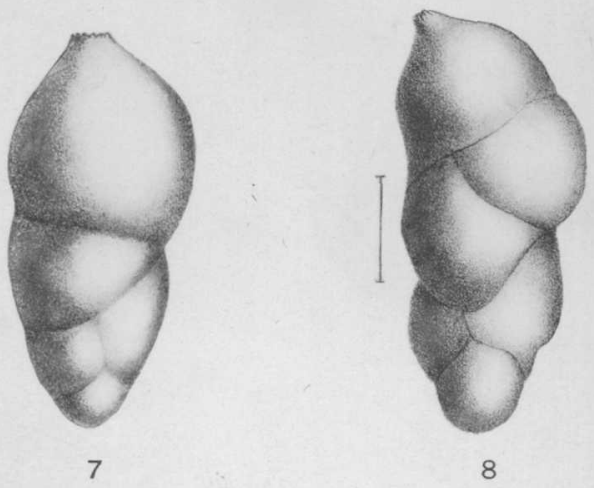
PLATE XX. 


\section{PLATE XX.}

Figures 1-3. Polymorphina problema D'Orbigny (=Guttulina austriaca D'Orbigny). (Foram. foss. Vienne, 1846, Pl. XII, figs. 23-25) .......... 73

Figures 4-6. Polymorphina problema D'Orbigny. (Idem, figs. 26-28) ....... 73

Frgures 7-9. Polymorphina compressa D'Orbigny. (Idem, figs. 32-34) ...... 69

Figures 10-12. Polymorphina oblonga D'Orbigny. (Idem, figs. 29-31) ...... 73

Figures 13, 14. Poiymorphina complanata D'Orbigny. San Pedro types, $\times 6 \ldots \quad 69$

Figures 15-18. Polymorphina trilocularis n. sp. San Pedro types, $\times 14,18$,

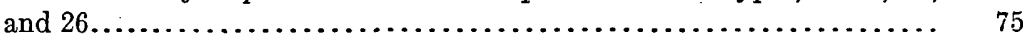

Figures 19-21. Polymorphina compressa D'Orbigny. San Pedrotypes, X 10.. 69 


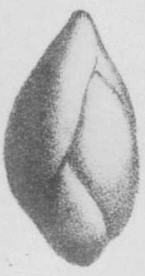

1

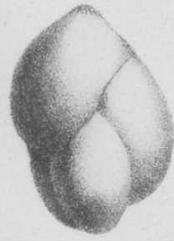

5

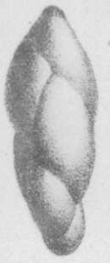

10

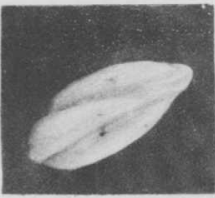

15

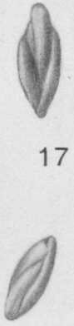

18
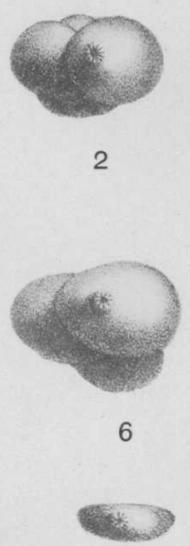

9

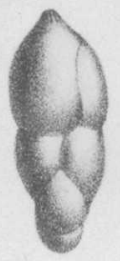

11

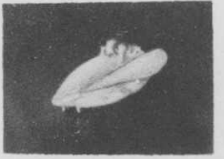

16

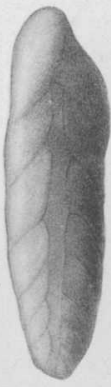

13
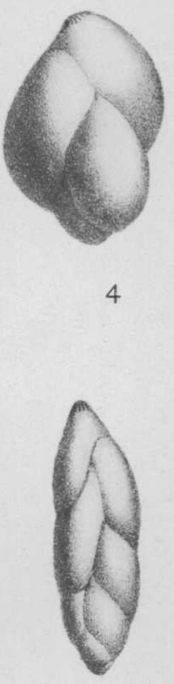

8

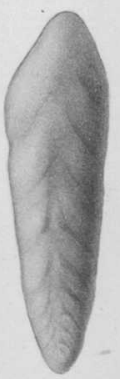

14

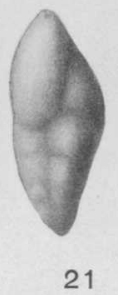

FORAM IN IFERA 
PLATE XXI. 


\section{PLATE XXI.}

Figure 1. Polymorphina nodosaria Reuss, typical form. (Sitzungsber. Akad. Wiss. Wien, vol. 48, 1863, Pl. VII, fig. 85)................... 71

Figures 2,3. Polymorphina nodosaria Reuss. Two San Pedro specimens, $\times 15 . \quad 71$

Figures 4, a-e. Polymorphina sororia Reuss. (Sitzungsber. Akad. Wiss. Wien,

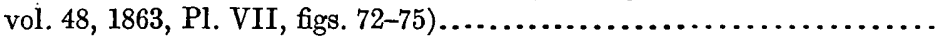

Figures 5, a, b. Polymorphina sororia Reuss. (After Jones, Foram. Crag, pt. 2: Paleont. Soc., vol. 49, 1895, Pl. VI, figs. 13, a, b) ...............

Figures 6, a, b. Polymorphina cylindroides Roemer. (After Jones, idem, figs.

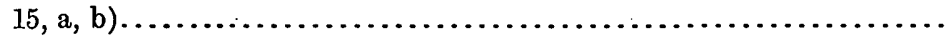

Figures 7, a, b. Polymorphina communis D'Orbigny. (After Jones, idem,

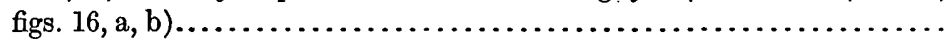

Figures 8, a, b. Polymorphina problema D'Orbigny. (After Jones, idem, figs.

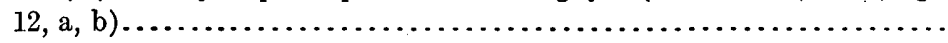

Figures 9, 10, 11, a, b. Polymorphina compressa D'Orbigny. (After Brady, Parker, and Jones, Trans. Linn. Soc. London, vol. 27, 1869, Pl. XL, figs. a-f. a (=fig. 9), a Recent specimen; b (=fig. 10), a Crag form; c (=fig. 11), a Miocene type.) This type variation in successive formations is one of the most striking examples of foraminiferal development and if one of these types is at all abundant it furnishes strong evidence, as to the identity of its horizon, for each appears to be practically fixed

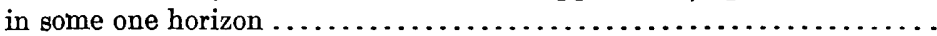

Figure 12. Polymorphina lactea (Walker and Jacob). (After Williamson, Recent Foram. Great Britain, 1858, Pl. VI, fig. 147)................

Figures 13-15. Polymorphina communis D'Orbigny. (After Williamson,

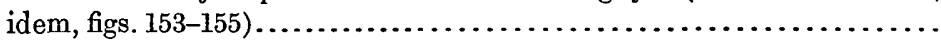

Figures 16, a, b. Polymorphina lactea (Walker and Jacob) var. elonga Williamson. (After Williamson, idem, figs. 149, 149a)...................

Figures 17, a, b. Marginulina glabra D'Orbigny. (After Brady, Challenger Rept., vol. 9, Pl. LXV, fgs. 5, 6b)......................... 

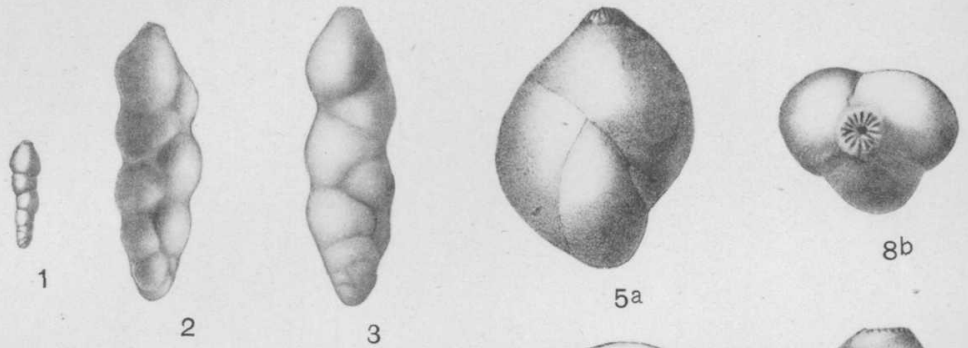

0000
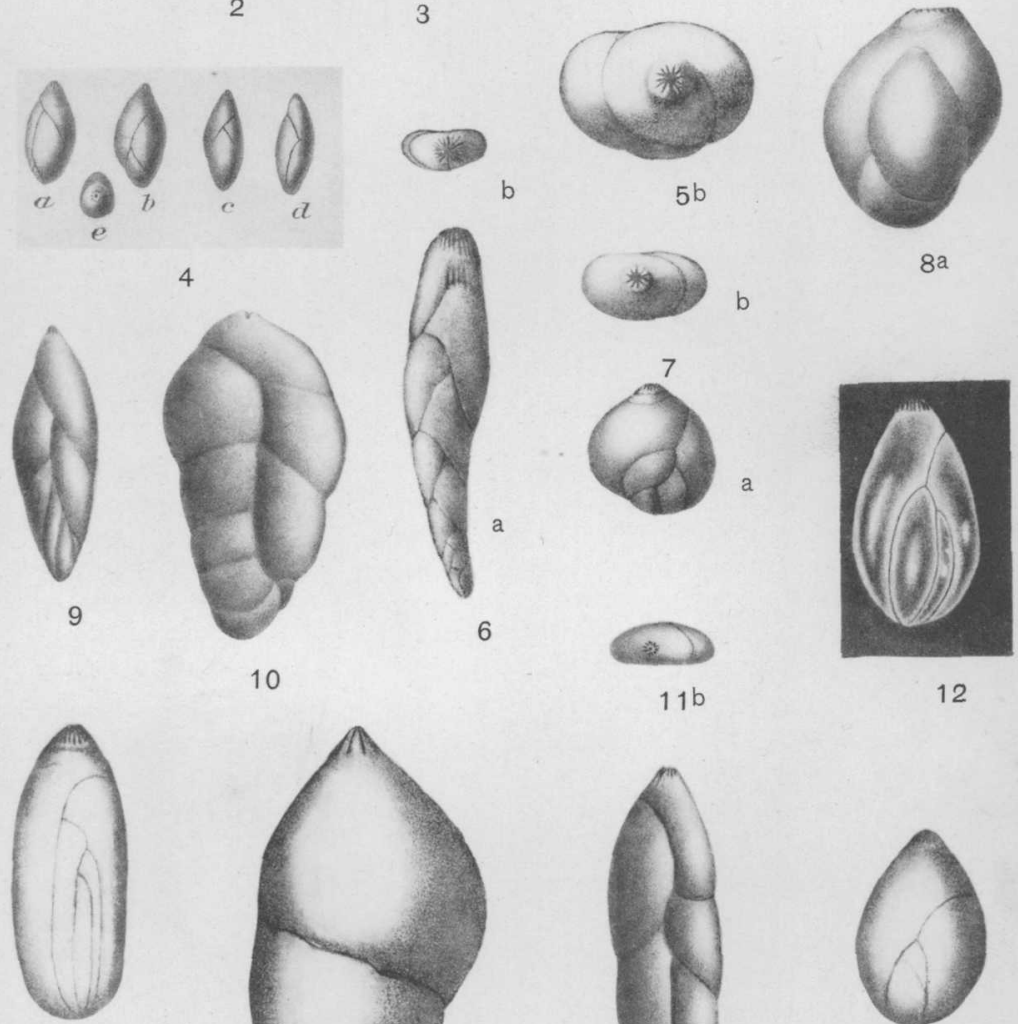

$16^{a}$
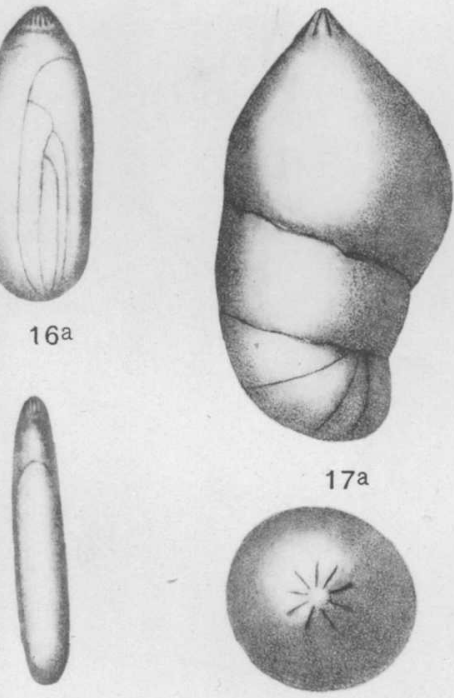

$17 a$
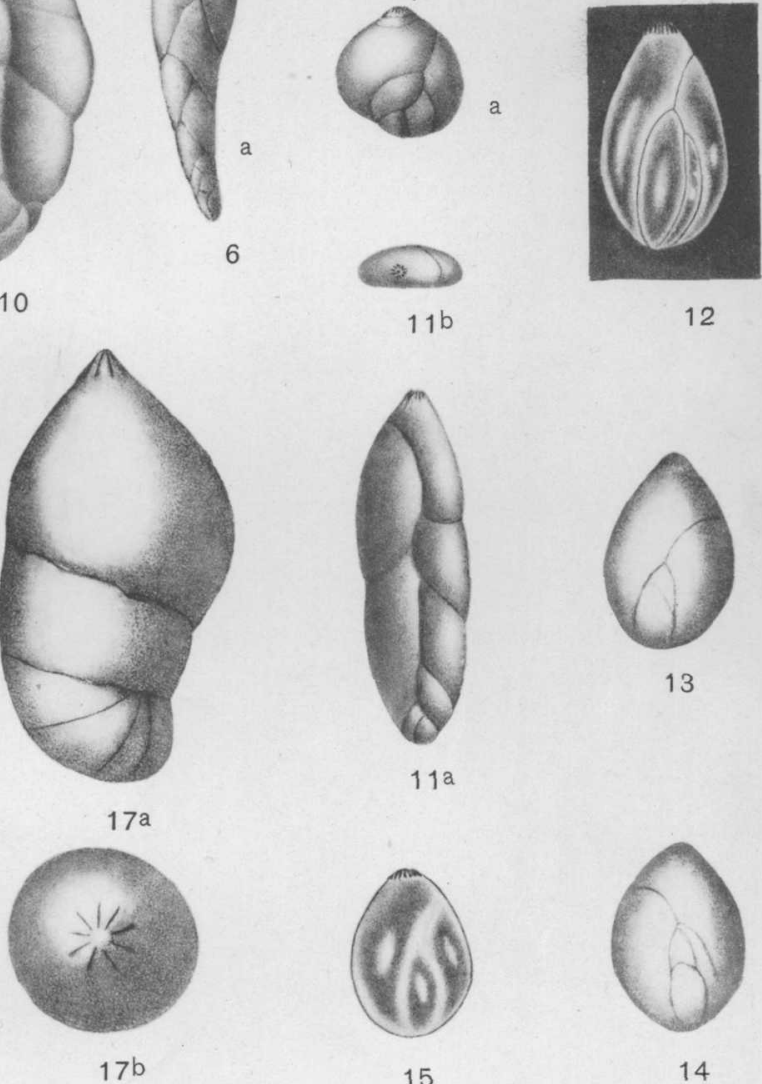

15

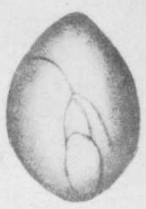

14

FORAMINIFERA 


\section{PLATE XXII.}




\section{PLATE XXII.}

Figures 1, a-c. Uvigerina canariensis D'Orbigny. (Goes, Kongl.' Svenska Vetenskaps-A kad. Handl., Bd. 25, No. 9, 1894, Pl. IX, figs. 489-491) .. Figures 2, a-f. Uvigerina angulosa Williamson. (Group of types after Goes, idem, figs. 502-507) .

Figures 3, a, b. Uvigerina pygmæa D'Orbigny. (After Brady, Challenger

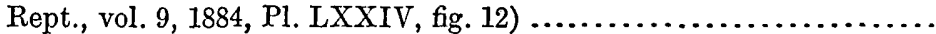

Figures 4, a-d. Globigerina dubia Egger. (Types in Challenger Rept., vol. 9,

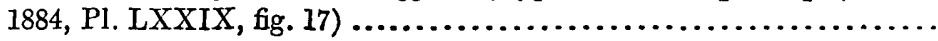

Page. 


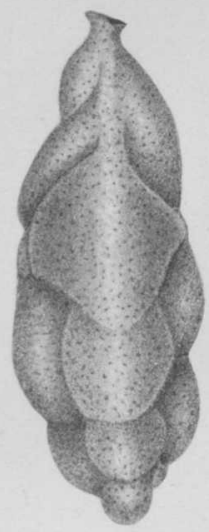

$1 \mathrm{a}$
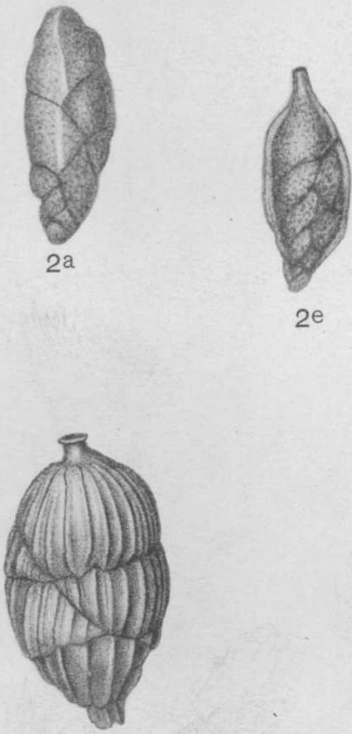

$3 a$

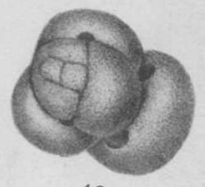

$4 a$

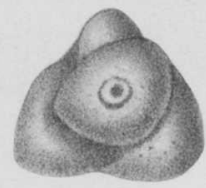

$1 b$

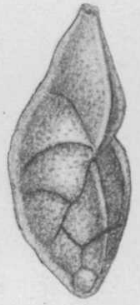

$2 c$

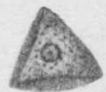

$2^{f}$

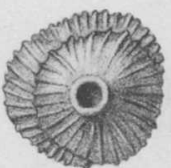

$3 b$

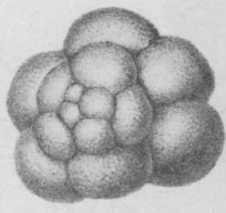

$4 d$

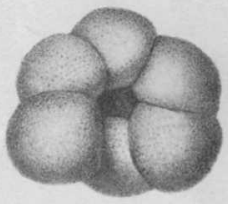

$4 c$

FORAMINIFERA 
PLATE XXIII. 


\section{PLATE XXIII.}

Figure 1. Orbulina universa D'Orbigny. (After Williamson, Recent Foram. Great Britain, 1858, Pl. I, fig. 4) ..........................

Page.

Figures 2, a-z. Globigerina bulloides D'Orbigny. (Group of 26 specimens by

- Goes, Kongl. Svenska Vetenskaps-Akad. Han dl., Bd. 25, No. 9, 1894,

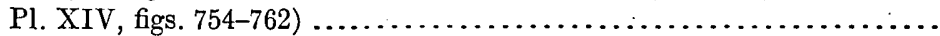

Figures 3-8. Globigerina bulloides D'Orbigny. Various forms of San Pedro specimens, $\times 30$. These types average about 0.24 millimeter in diameter, but the species is very variable in regard to its size..............

Figures 9, 10, a, b. Uvigerina tenuistriata Reuss. (After Brady, Challenger

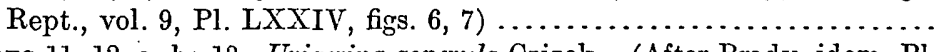

Figures 11, 12, a, b; 13. Uvigerina asperula Czjzek. (After Brady, idem, PI.

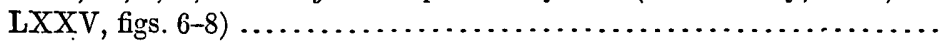




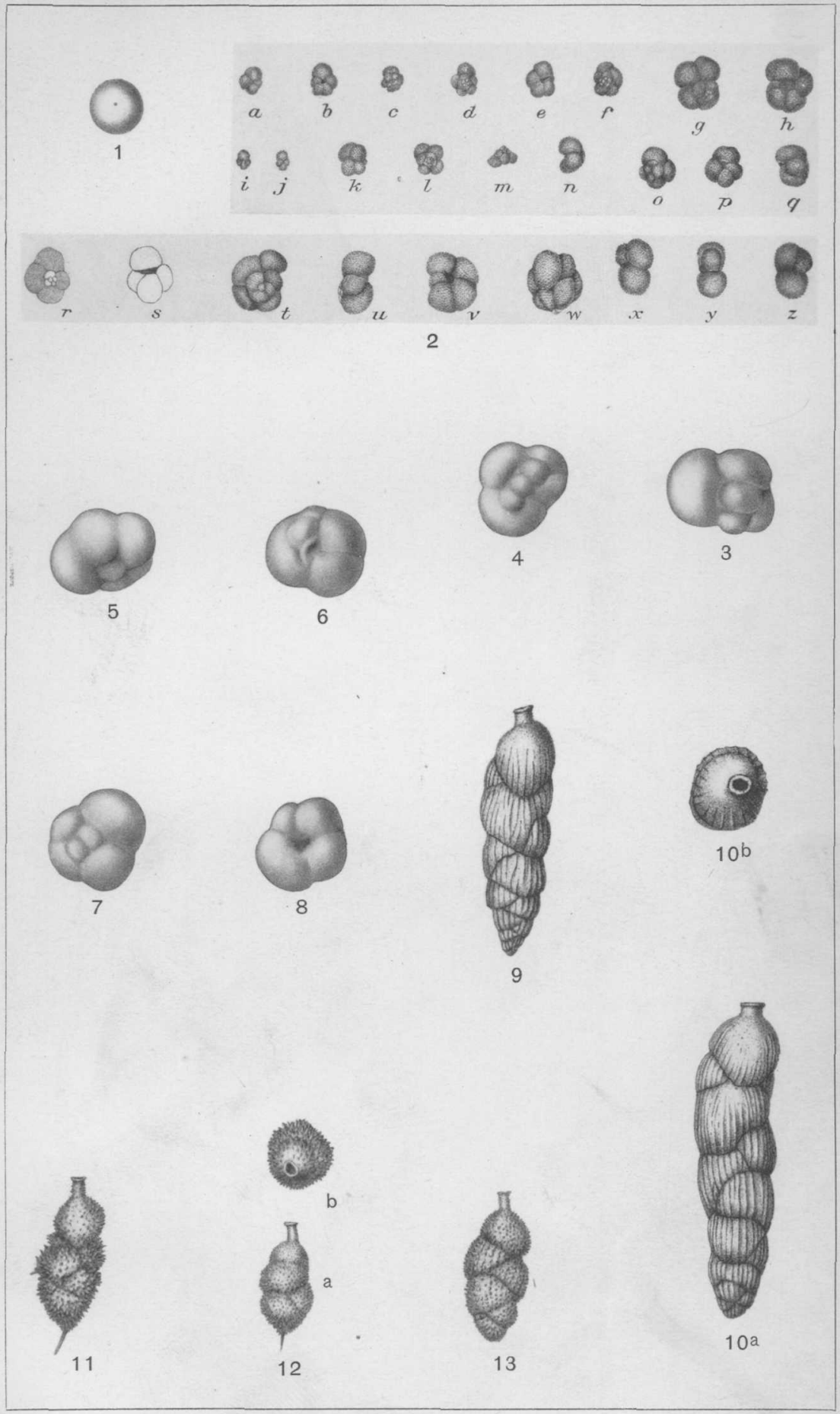

FORAMINIFERA 


\section{PLATE XXIV.}




\section{PLATE XXIV.}

Figures 1,2 , a, b; 3, 4. Truncatulina variabilis D'Orbigny. Drawings of several typical forms of this exceedingly variable species, $\times 15 \ldots \ldots \ldots$

Figures 5-8. Pulvinulina repanda (Fichtel and Moll). Drawings of San Pedro types, $\times 10 \frac{1}{2}$. The specimens vary in size, but average about 1.2 to 1.5 millimeters in their shortest diameter.

Page.

Figures 9-14. Truncatulina lobatula (Walker and Jacob). Drawings of San Pedro specimens (figs. 13 and $14, \times 40$; figs. 9 and $10, \times$ about 30 )....

Figure 15. Discorbina globularis (D'Orbigny). Carpenter (after Schultze), Introduction Study Foram., 1862, Pl. III, fig. 1, showing pseudopodia in a living specimen) 


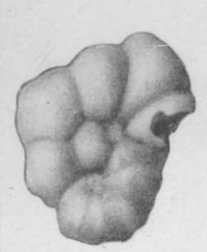

1

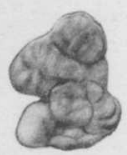

4

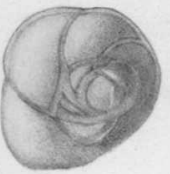

7

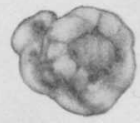

11

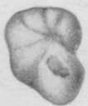

12
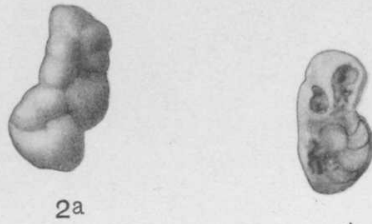

$2 b$
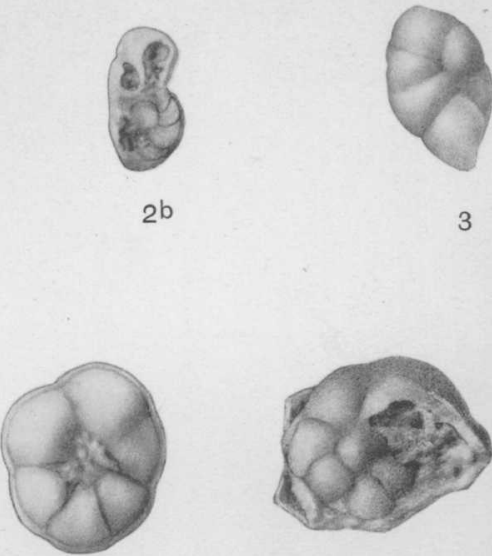

$5 b$
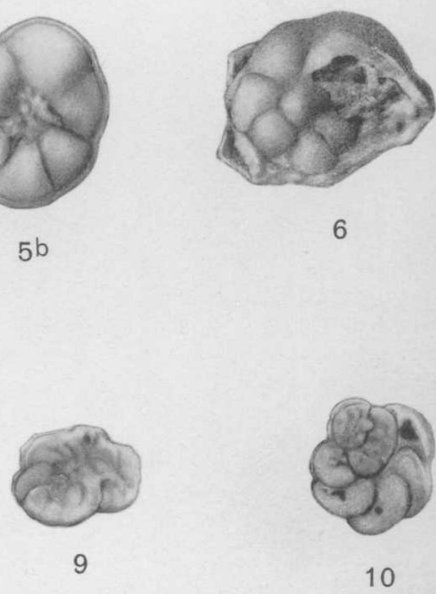

8

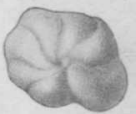

13

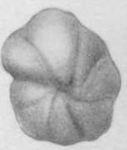

14

FORAMINIFERA 


\section{PLATE XXV.}




\section{PLATE XXV.}

Page.

Figures 1-3. Truncatulina ungeriana (D'Orbigny). (After D'Orbigny's drawing, Foram. foss. Vienne, 1846, Pl. VIII, figs. 16-18)........... 83

Figures 4, 5. Truncatulina variabilis (D'Orbigny). (Challenger Rept., vol.

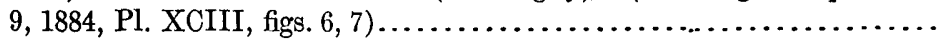

Figures 6-9. Pulvinulina punctulata (D'Orbigny). San Pedro forms, $\times 15$. The diameter of the shell in San Pedro types is from 1 to 1.4 millimeters.

Figures 10, a-c. Truncatulina wuellerstorfi (Schwager). (Challenger Rept.,

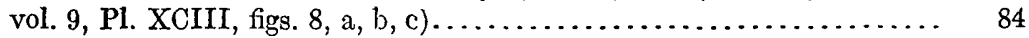

Figures 11, a-c. Truncatulina wuellerstorfi (Schwager). (Idem, figs. 9, a-c)... These two types show the variation in this species from a rather low complanate to a highly plano-convex type, but the definite arcuate chamber development is maintained in all forms.

144 


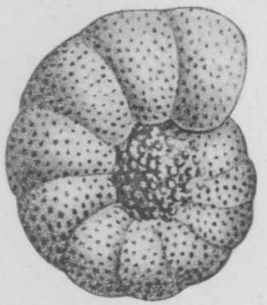

1
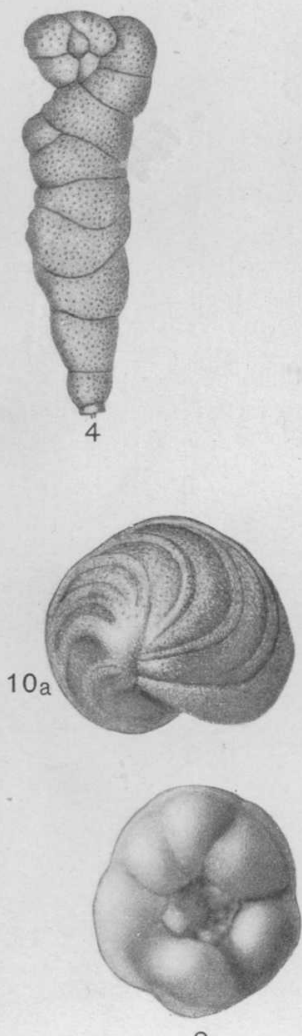

8

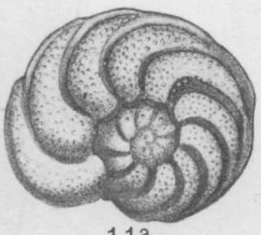

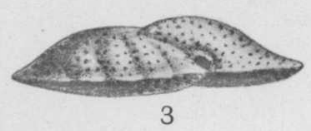
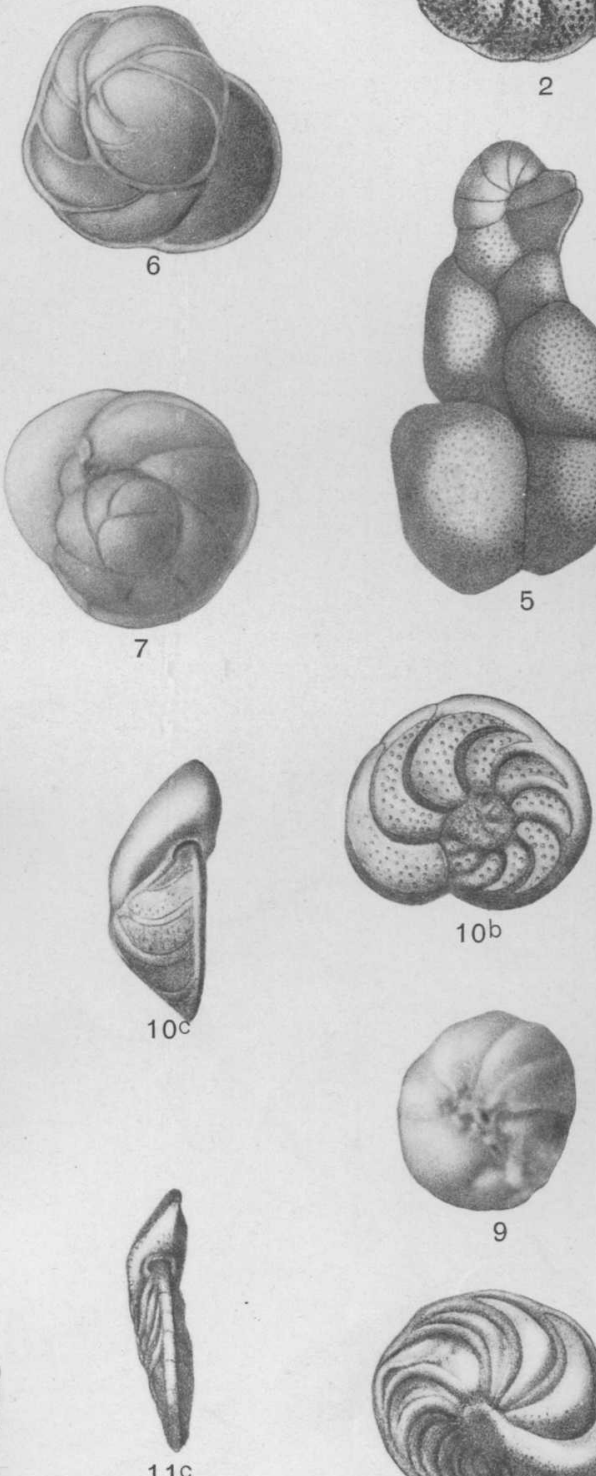

$11 \mathrm{c}$
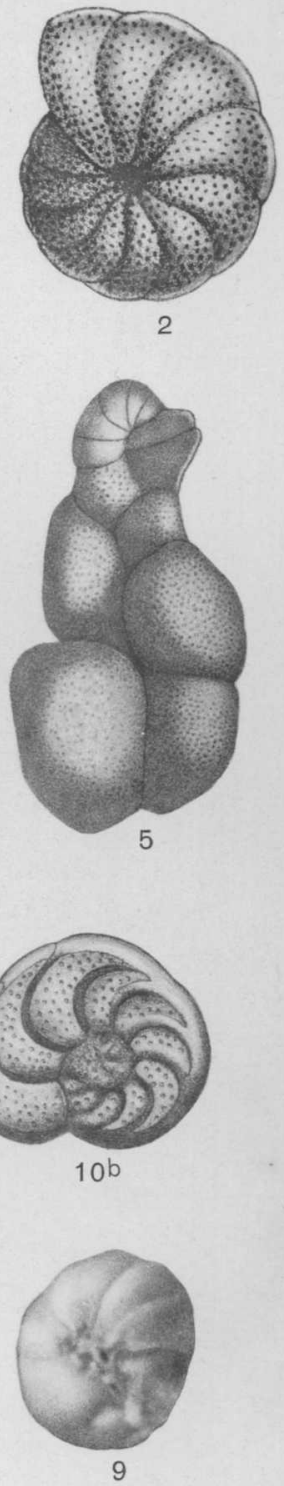

$10 \mathrm{~b}$

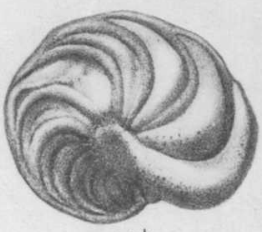

$11 \mathrm{~b}$

FORAMINIFERA 
PLATE XXVI. 


\section{PLATE XXVI.}

Figures 1-6. Anomalina grosserugosa (Gumbel). (Challenger Rept., vol. 9,

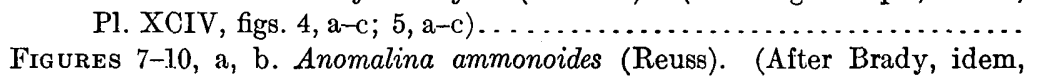

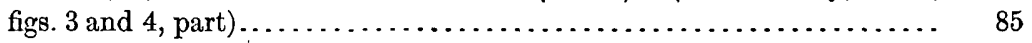

Frgures 11-14. Pulvinulina elegans (D'Orbigny). (Idem, Pl. CV, figs. 3-6).. • 86

Figures 15, a-c. Complanate types of Pulvinulina elegans (D'Orbigny).

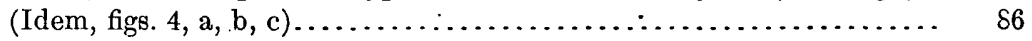

Figures 16, a-c. Nonionina depressula (Walker and Jacob). (Idem, Pl.

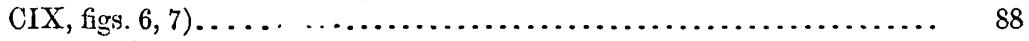

146 


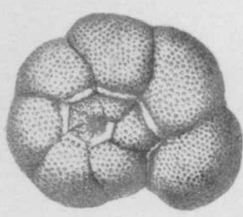

1
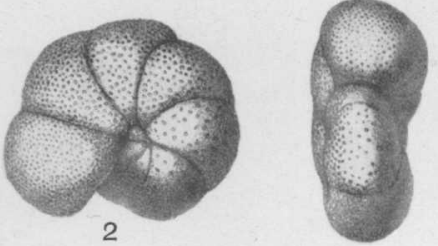

3

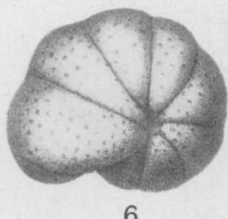

5

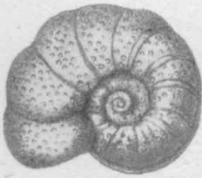

9

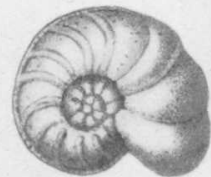

a
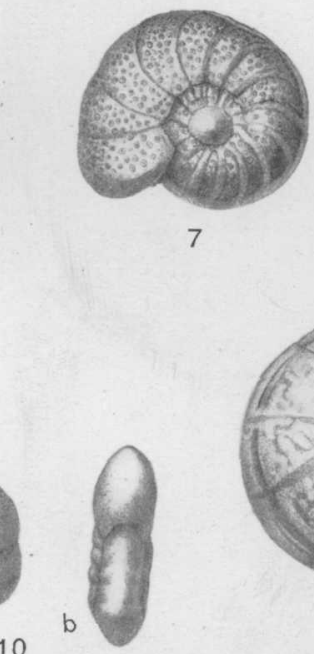

7

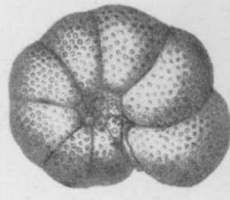

4

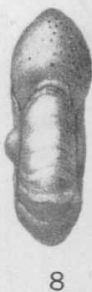

8

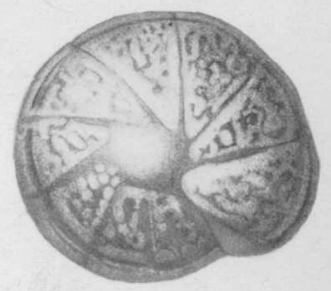

11

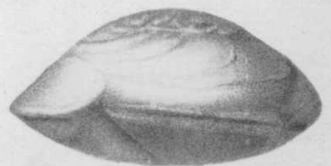

12

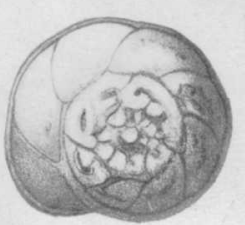

a
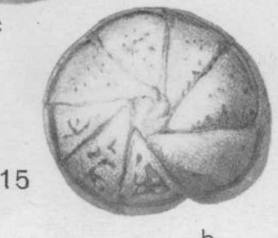

b
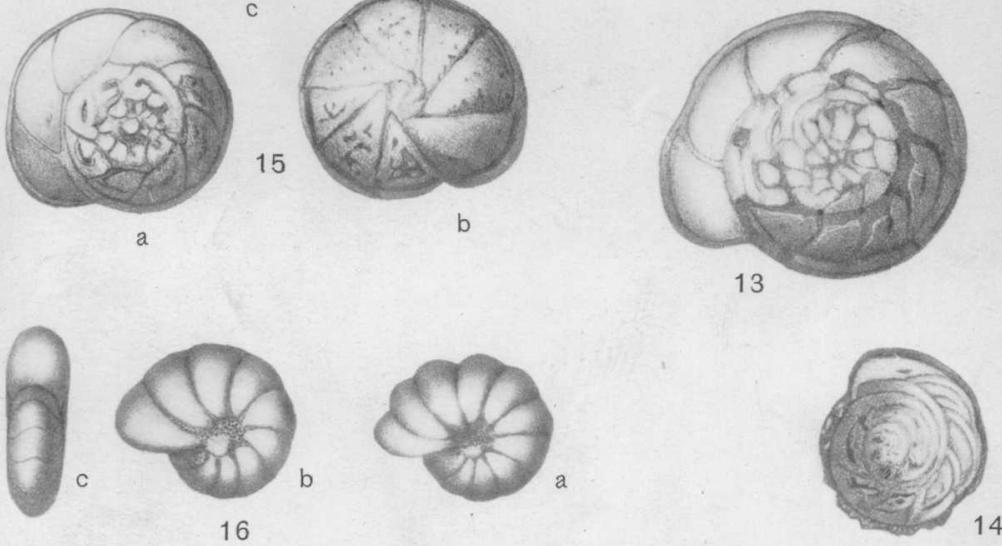


\section{PLATE XXVII.}

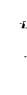




\section{PLATE XXVII.}

Figures 1, a, b; 2, 3. Nonionina scapha (Fichtel and Moll). (After Brady, Challenger Rept., vol. 9, Pl. CIX, figs. 14-16).................. Figures 4-6. Nonionina umbilicatula (Montagu). (Idem, figs. 8, a, b; 9).... Figures 7, 8. Nonionina stelligera D'Orbigny. (Idem, figs. $3, \mathrm{a}, \mathrm{b} ; 5) \ldots \ldots$. Frgures 10-12. Polystomella striatopunctata (Fichtel and Moll). (After

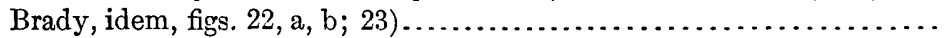
Figures 13-20. Polystomella crispa (Linnæus). Eight specimens from Cali-

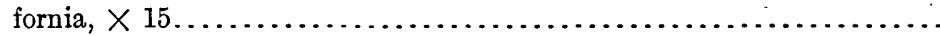

Page. 89 


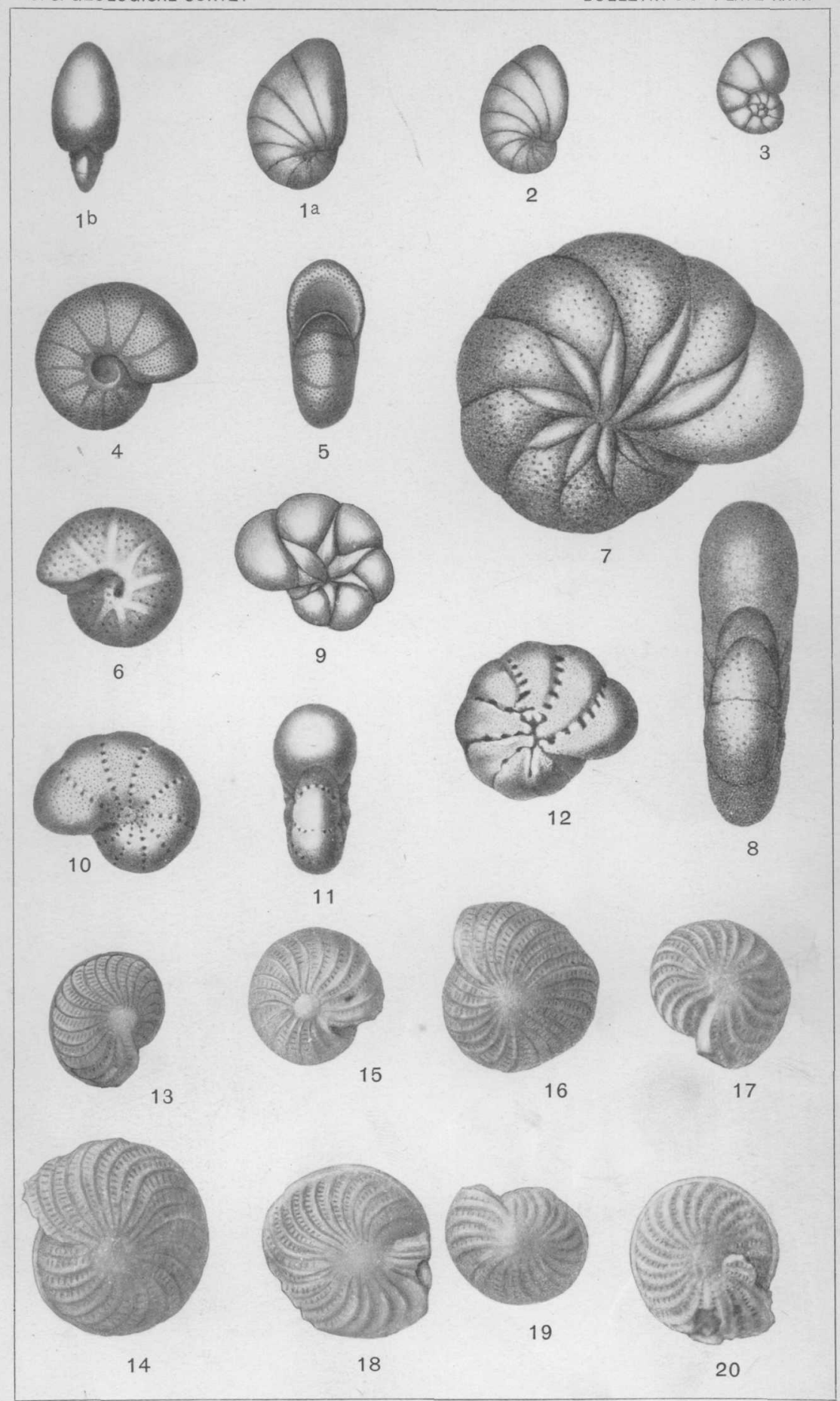

FORAMINIFERA 

$=$

\section{PLATE XXVIII.}




\section{PLATE XXVIII.}

Figures 1-6. Polystomella crispa (Fichtel and Moll). San Pedro types, $\times 1.5$. These shells are somewhat waterworn, showing wave work, but they are very typical specimens of this species of Polystomella...............

Figures 7, 8. Nonionina depressula (Walker and Jacob). San Pedro type,

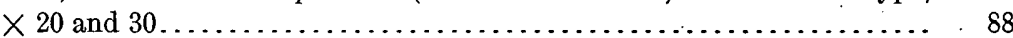

Figures 9, a-c. Discorbina vilardeboana (D'Orbigny). (Challenger Rept.,

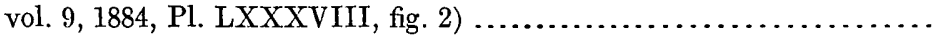
Figures 10, 11, a, b. Discorbina bertheloti (D'Orbigny). (Idem, Pl. LXXXIX,

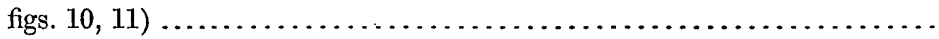

Figures 12, a, b. Polystomella subnodosa (Munster). (After Brady, idem, Pl.

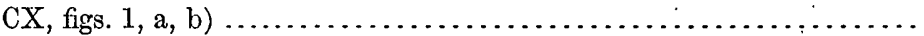

Figures 13, a-e. Various otoliths from San Pedro sands, $\times 7$. From drawings.. 

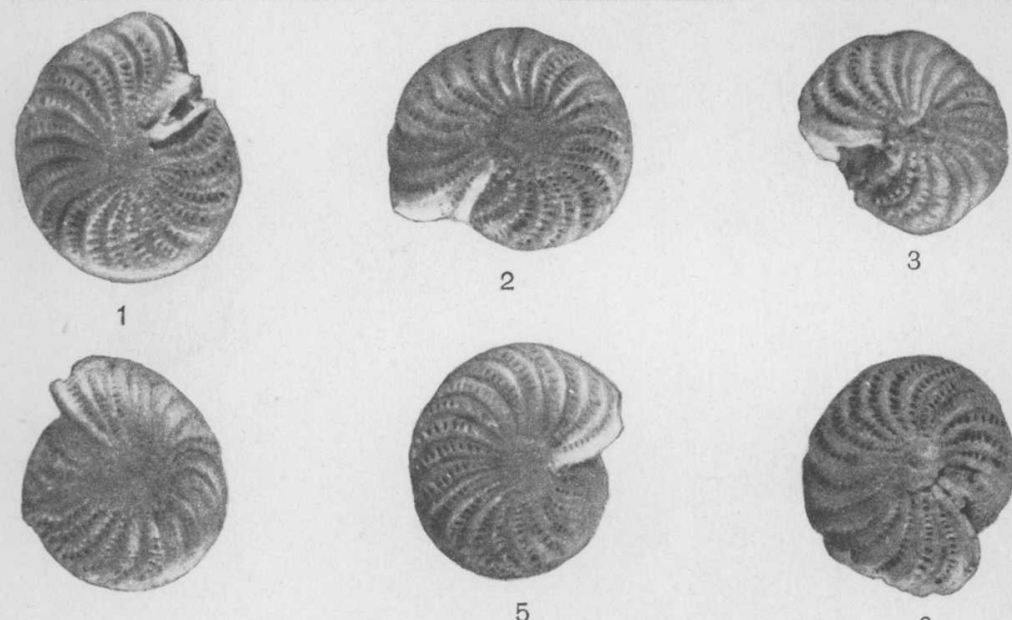

4

5

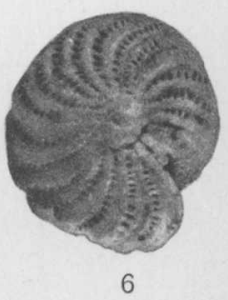

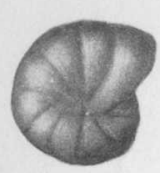

7

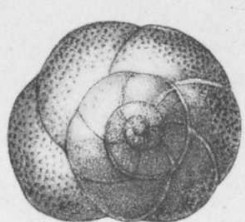

a
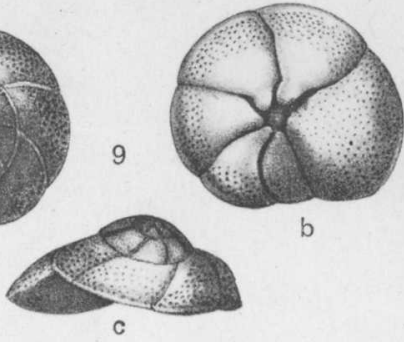

b
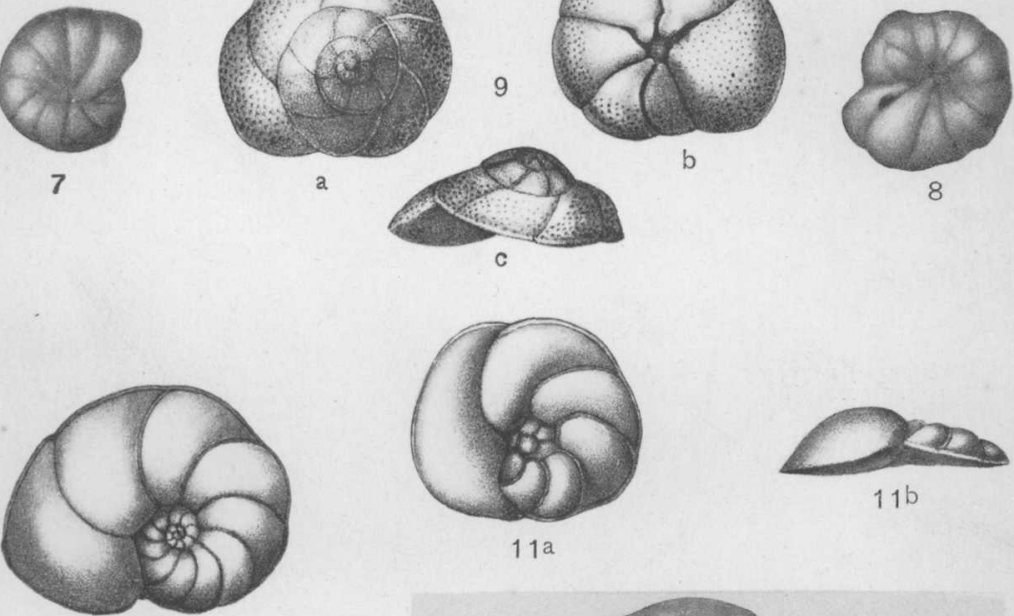

$11 \mathrm{a}$

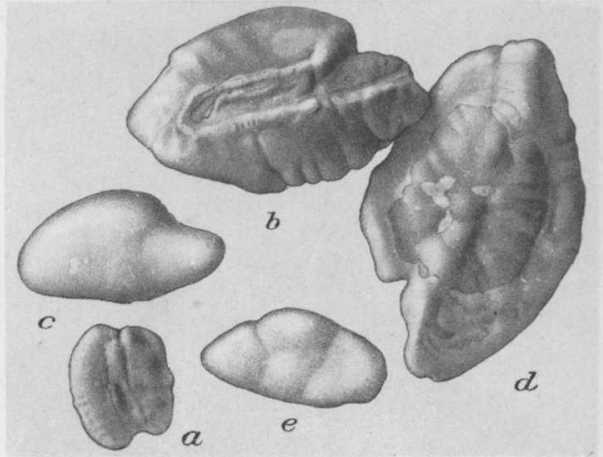

FORAMINIFERA 


\section{INDEX.}

Names in italic are synonyms; figures in italic denote illustrations; figures in black face denote descriptions.

A.

Adelosina pulchella D'Orbigny

Anomalina ammonoides (Reuss) ........ 15,85,146 grosserugosa (Gumbel) ........... 15,85,146 wuellerstor $f i$ Schwager.

Arnold, Delos, reference to Ralph, reference to

Ataxophragmium simile harrer.

\section{B.}

Bibliography.

Biloculina bulloides, $D$ 'Orbigny... $15,23,96,98,102$ depressa D'Orbigny $15,23-24,98$ var. murrhina Schwager $15,24,98$ elongata D'Orbigny. $15,24-25,96,98$ lævis (Defrance). $15,25,96,100$ murrhina Schwager ringens (Lamarck) ....... $5,7,15,25-26,96,100$ var. patagonica Williamson............. 24

Bolivina antigua $\mathrm{D}$ 'Orbigny. beyrichi Reuss.

$15,40,114$ var. alata, Seguenza $15,40,114$ dilatata Reuss.

, 40-41,116 nobilis Hantken $15,41,114$ punctata D'Orbigny............... 15, $\mathbf{4 1 , 1 1 4}$ robusta Brady................... 15,42,114 textilarioides Reuss.............. 15,42,116

Branner, J. C., acknowledgment to

Bulimina affinis contraria (Reuss) convoluta Williamson ............ 15,37,112 elegantissima D'Orbigny.......... 15,38,118 ovata D'Orbigny............... 15,38,112 pupoides....................... 38,112 pyrula D'Orbigny.............. 12, 15,39,112 subteres Brady............... 15,39,112,116

Burseolina calabra Seguenza.

\section{C.}

Cassidulina calabra (Seguenza)...... 15,42-43,118 crissa D'Orbigny............... 5, 15,43,118 lavigata $D^{\prime} O$ rbigny........ 5, 7, 15,43-44,118 obtusa Williamson. subglobosa Brady... $5,7,15,44,118$

Cibicides refulgens Montfort.

Crag strata, English, classification of... correlation of San Pedro Pliocene beds with.

Cristellario crepidula (Fichtel and Moll)

(De

Dentalina communis D'Orbigny.

Parker and Jones................. 53

divergens Reuss..................... 65

emaciata Reuss....................... 55

pauperata D'Orbigny................. 57

seminuda Reuss....................... 59

soluta Reuss....................... 59

Dimorphina nodosaria Jones, Parker, and Brady.................... 71,72 tuberosa D'Orbigny.......... 16, 68, $: 2-73,182$

Discorbina bertheloti (D'Orbigny)....... 16, 80,150 berthelotiana Goes.................... 80 globularis (D'Orbigny) ........... 16,81,142 turbo (D'Orbigny ................... 16,81 vilardeboana (D'Orbigny)......... 16,82,150

E.

Entosolenia costata Williamson.............. 52

globosa Williamson.................. 46

marginata Williamson................ 49

var. lagenoides Williamson........... 48

var. quadrata Williamson............ 50

squamosa Williamson................... 51

F.

Flabellina inæqualis Brady................. 60

Foraminifera, bathymetric distribution of , .. 12,14 favorable conditions for............... 13 of California, Arctic character of........ 11 outline classification of ................ 21-22 Tertiary and Pleistocene, correlation table of .................... 15-19 Frondicularia inæqualis Costa........ $5,16,60-61$ levigata Karrer.................... 16,61

G.

Gaudryina pupoides D'Orbigny ......... 16, 36, 110 rugosa D'Orbigny.............. 16, 36-37, 108 Globigerina bulloides D'Orbigny...5, 14, 16,77-78, 140 dubia Egger................... 16, 79, 198 
Globigerina ooze................... $\begin{array}{r}\text { Page. } \\ 78-79\end{array}$

Guttulina austriaca..................... 73 problcma D'Orbigny............... 73

H.

Haplophragmium canariense (D'Orbigny) ... 16, L.

33-34, 108

Lagena acuticosta Reuss.............. 16,45, 122 apcnaiculata (Williamson) Rcuss....... 48 dentaliformis, n. sp.............. 10, 45,120 elongata (Ehrenberg)............. 16,46,120 globosa (Montagu)................ 10,46,120 gracilis Williamson.............. 16,47, 122 gracillima (Seguenza).............. 16,47, 120 lævis (Montagu) ............ 5, 17,48, 120,122 lagenoides (Williamson)..........17, 48-49, 122 marginata (Walker and Boys)... 5, 7, 17,49, 122 melo (D'Orbigny) ............... $7,17,49,122$ quadrata (Williamson) ............ 17,50,122 semistriata Williamson............. 17,50,122 sesquistriata, $\mathrm{n}$. sp.............. 17, 50-51, 120 squamosa (Montagu) ............. 17,51, 12: striata (D'Orbigny) .......... 7, 17,51-52,182 striatopunctata Parker and Jones.... 17, 52, 122 sulcata (Walker and Jacob)....... 17, 52-53, 122 var. distoma-polita Parker and: Jones. . vulgaris Williamson var. perlucida (pars) Williamson..... var. striata Williamson.............. var. substriata.

Lenticulites rotulata Lamarck

M.

Marginulina costata (Batsch) .......... 17,62,130 glabra D'Orbigny.............. 17, 62-63, 136 inæqualis Reuss.

Miliola (Biloculina) elongata Parker and Jones.........................

elongata Ehrenberg

Miliolina auberiana (D'Orbigny) . 17, 26-27, 102, 106 bicornis (Walker and Jacob). 17,27, 100, 102, 104 circularis (Bornemann).......... 17, 27-28,100 cuvieriana (D'Orbigny) .......... 12, 17, 28, 106 linnæana (D'Orbigny)........... 17, 28-29, 100 oblonga (Montagu) .............. 17,29, 102 pulchella (D'Orbigny)........ 12,17, 29-30, 104 pygmæa (Reuss) ................ 17,30,104 seminulum (Linnæus)........ 5, 7, 17, 30-31, 102 subrotunda (Montagu) ................ 27-28 triangularis (D'Orbigny).......... 17, 31, 102 tricarinata (D'Orbigny) ......... 17,31, 104, 106 trigonula (Lamarck)............. 17,32, 102, 106 venusta (Karrer) ............... 17, 32, 106

Miliolites ringens Lamarck. trigonula Lamarck.

N.

Nautilus crepidula Fichtel and Moll crispa Linnæus........ depressulus Walker and Jacob........... legumen Linnæus..

linearis Montagu.

lobatulus Walker and Jacob obliquus Linnæus.
Nautilus (Orthoceras) vertebralis Batsch..... $\quad 60$

(Orthoceras) costatus Batsch........ 62 repandus Fichtel and Moll.............. 87 scapha Fichtel and Moll.............. $\quad 88$ stria opunctatus Fichtel and Moll........ 92 umbilicatula Montagu................. 90

Nodosaria calomorpha Reuss.......... 17,53,124 communis (D'Orbigny) $\ldots \ldots \ldots \ldots \ldots 17,54,126$ consobrina D'Orbigny............. 17,54,12/4 var. emaciata Reuss........ 17,55,12, 126 decepta, n. sp................. 17, 55-56,126 farcimen (Soldani) . . . . . . . . . . . $1 \bar{i}, 56,128$ obliqua (Linnæus)........... 17, 57, 124,128 pauperata (D'Orbigny)........ 5, 17, 57-58,126 sagrinensis, n. sp................ 17, 58, 126 seminuda, Reuss................ 17,59, 126 soluta (Reuss)............... 18, 53, 194, 126 sp.............................. 124 vertebralis (Batsch) $\ldots \ldots \ldots \ldots \ldots \ldots, 18,60,128$

Nonionina canariense D'Orbigny........... 33 depressula (Walker and Jacob)...18, 88, 146, 150 scapha (Fichtel and Moll)........ 18,88-89, 148 jeffreysii Williamson................. 33 soldanii D'Orbigny:.................. 90 stelligera D'Orbigny............. $7,18,89,148$ umbilicatula (Montagu)........... 18,90, 148

o.

Oolina melo D'Orbigny ................. 49 striata D'Orbigny .................... 51 Orbulina universa D'Orbigny....... 18,79-80,140 Orthoceras farcimen Soldani............... 56 Otoliths from San Pedro. figures showing... 150

$$
P \text {. }
$$

Planorbulina wuellerstorfi Goes............. 8 Pleistocene deposits, Santa Barbara, correlation of..................... 7 Santa Barbara, species identified in.... 8 Pleistocene fossils, source of . . . . . . . Pliocene deposits, European, classification

of ............................. 7

San Pedro, correlation of . ............ 6,8-11

Pliocene fossils, source of .............. $5-6$ Polymorphina communis D'Orbigny. $18,68-69,186$ complanata D'Orbigny............ 5, 18,69,184 compressa D'Orbigny ...... 5, 18,63-70, 134,186 cylindroides Roemer........... 18,70-71,196 lactea (Walker and Jacob)......... 18, 71, 186 nodosaria Reuss.............. 18,71-73,136 oblonga D'Orbigny................ 18,73,194 problema D'Orbigny........ 18, 73-74, 134,196 soldanii D'Orbigny.............. 18,72,74,198 sororia (Reuss)............... 18,74-75, 186 trilocularis, n. sp................. 18,75, 194

Polystomella crispa (Linnxus)... 18,90-91, 148, 150 crispa var. stelligera Parker and Jones ... 89 striatopunctata (Fichtel and Moll)... 18,92,148 subnodosa (von Munster) ......... 18,92,150

Pulvinulina elegans (D'Orbigny) ......... 18,86,146 punctulata (D'Orbigny).......14, 18, 86-87, 144 repanda (Fichtel and Moll).... 12, 14, 18, 87, 142 Pyrgo lævis Defrance................... $\quad 25$ Q.

Quinqueloculina auberiana D'Orbigny........ 26 cuviesiana D'Orbigny................... 28 
Quinqueloculina lamarckiana D'Orbigny..... 28

lucida Karrer.

pygma $a$ Reuss.

tenuis Czjzek.

triangularis $\mathrm{D}$ 'Orbigny.

ungeriana D'Orbigny.

venusta Karrer.

$\mathrm{R}$.

Robulina subnodosa von Munster

Rosalina ammonoides Reuss

bertheloti D'Orbigny.

globularis D'Orbigny...

vilardcboana D'Orbigny.

Rotalia punctulata D'Orbigny...

( Trochulina) turbo D'Orbigny

Rotalina contraria Reuss.

( Turbinulina) elegans D'Orbigny........

ungeriana D'Orbigny

S.

Sagrina virgula Brady

San Pedro, Cal., section along water-front at, figure showing..................

section on Deadman Island at, figure showing

stratigraphy at.

9-11

and vicinity, map of.

10

Santa Barbara, Cal., pleistocene specimens from ..................... 6,7-8

Scrpula bicornis Walker and Jacob.......... 27 lactea Walker and Jacob................ 71

(Lagena) marginata Walker and Boys.... scminulum Linnæus.

sulcata Walker and Jacob...............

Sigmoilina (Spiroloculina in part) tenuis

$$
\text { (Czjzek). }
$$

$18,33,110$

Spiroloculina tenuis Brady
T.

Page.

Textularia abbreviata D'Orbigny..... 19, 34-35, 108 agglutinans D'Orbigny ............. 19, 35, 108 nusdorfensis D'Orbigny................. 35 sagittula Defrance............. 19,35-36, 110

Triloculina austriaca D'Orbigny.............. 32 circularis Bornemann................... $\quad 27$ gibba D'Orbigny ..................... 31 linnæana D'Orbigny................... 28 tricarinata D’Orbigny................. 31

Trochammina trullissata Brady........ 19,34,108

Truncatulina boueana D'Orbigny............ 82 grosserugosa Gumbel................ 85 lobatula (Walker and Jacob)... 12, 19, 82-83, 148 refulgens (Montfort) $\ldots \ldots \ldots \ldots \ldots \ldots \ldots 12,19,83$ ungeriana (D'Orbigny) ........ 19,83-84, 144 variabilis D'Orbigny............ 19,84,142,144 wuellerstorfi (Schwager)........ 19,84-85, 144

U.

Uvigerina angulosa Williamson........ 19,75,188 asperula Czjzek .................. 19,76,140 canariensis D'Orbigny............ 19,76,198 pygmæa D'Orbigny ...........12, 19,76-77, 188 tenuistriata Reuss............... 19,77, 140 urnula D'Orbigny..................... 76

\section{V.}

Vaginulina badenensis D'Orbigny ....... 19,63,180 legumen (Linnæus)........... 12, 19,63-64,180 var. arquata Brady.......... 19,64,180 linearis (Montagu) ............... 19,64,180 obliquistriata Jones............... 19,65, 180

Vermiculum Montagu..................... 29 globosum Montagu...................... 46 læve Montagu........................ 48 squamosum Montagu................... 51

Vulvulina alata Seguenza................. 40 gramen D'Orbigny ................. 40 